\title{
Editors-in-chief:
}

\section{Historical and Natural Sciences}

Lienara Adzhyieva

Social, Pedagogy Sciences \& Humanities

Heyder Guliyev

Economic, Management \& Marketing Sciences

Badri Gechbaia

Liza Alili Suleymani

Medicine

Gulnara Kiliptari

\section{VOLUME 17 ISSUE 072021}

ISSN: 2613-5817; E-ISSN: 2613 - 5825; UDC: 0 (0.034); DOI: 10.36962/PIRETC

PROCEEDINGS OF THE INTERNATIONAL RESEARCH, EDUCATION \& TRAINING CENTER

CPublisher: NGO International Center for Research, Education and Training. R/C: 80550594

MTÜ Rahvusvaheline Teadus-, Haridus- ja Koolituskeskus.

CPublisher: NGO Azerbaijan International Diaspora Center in Georgia.

Management Board Member and founder of organization: Seyfulla Isayev.

CEditorial office: Narva mnt 5, 10117 Tallinn, Estonia.

(CTypography: NGO International Research, Education \& Training Center. The Baltic Scientific Journals.

Registered address: Narva mnt 5, 10117 Tallinn, Estonia.

Tel: +994 5524170 12; +994518648894

E-mail: gulustanbssjar@gmaill.com, sc.mediagroup2017@gmail.com

Website: https://scia.website/

\section{OFFICIAL REPRESENTATIVES-COORDINATORS}

Namig Isazade (EU, Azerbaijan)

+ 994552417012

Accepted for publication in this edition 12.12.2021

(C)The Baltic Scientific Journals. NGO ICRET. All rights reserved. Reproduction, store in a retrieval system, or transmitted in any form, electronic, mechanic photocopying of any publishing of The Baltic Scientific Journals permitted only with the agreement of the publisher. The editorial board does not bear any responsibility for the contents of advertisements and papers. The editorial board's views can differ from the author's opinion. The journal published and issued by NGO ICRET. International Center for Research, Education \& Training. R/C 80550594. Non-profit Associations and Foundations Register as at 21.05.2018 


\section{TABLE OF CONTENTS}

Lali V. Tabatadze, Neli N. Sidamonidze, Darejan B. Gulbani, Darejan J. Iremashvili SYNTHESIS AND BIOLOGICAL ACTIVITY OF $\beta$-O-(2,3,4,6-TETRA-O-ACETYLD-GALACTOPYRANOSYL)-2-METHYL-4-BROMO PENTANOATE

Konul Valiyeva

KARABAKH'S TOURISM PROSPECTS AS A KEY FACTOR IN THE DEVELOPMENT OF THE NATIONAL ECONOMY

\section{Orkhan Hajizada}

ISSUES OF INTEGRATION INTO THE GREEN ECONOMY IN THE REPUBLIC OF AZERBAIJAN

Karim Seyidrza, Bakhtiyar Ismayilov, Zulfiya Mammadova DETERMINING THE EFFECT AND EFFICIENCY OF INVESTING IN HUMAN CAPITAL

Ainur Tokshilykova, Zhanslu Sarkulova, Zhusupbek Satenov, Marat Sarkulov, Arzyhiya Tleuova, Botagoz Kalieva, Kamila Daniyarova, Adina Darbaeva PROGNOSTIC MEANING OF SERUM NSE AS THE FACTOR OF BAD OUTCOME IN SECONDARY BRAIN DAMAGE

Ahliman Amiraslanov, Sevinj Abdiyeva, Azer Amiraslanov, Elnur Ibrahimov, Habil Muradov IMMUNOHISTOCHEMICAL FEATURES IN SOFT TISSUE SARCOMAS

Ainur Tokshilykova, Zhanslu Sarkulova, Gulnar Kabdrakhmanova, Marat Sarkulov, Aigul Utepkaliyeva, Botagoz Kalieva

THE LEVEL OF S100 IN BLOOD SERUM AS A PROGNOSTIC FACTOR OF OUTCOME IN SECONDARY BRAIN LESIONS 


\title{
SYNTHESIS AND BIOLOGICAL ACTIVITY OF $\beta$-O-(2,3,4,6-TETRA-O- ACETYL-D-GALACTOPYRANOSYL)-2-METHYL-4-BROMO PENTANOATE
}

\author{
Lali V. Tabatadze ${ }^{1}$, Neli N. Sidamonidze ${ }^{2}$, Darejan B. Gulbani ${ }^{3}$, Darejan J. Iremashvili ${ }^{4}$ \\ ${ }^{1}$ Doctor of Chemical Sciences, Professor, Sokhumi State University \\ ${ }^{2}$ Doctor of Chemical Sciences, Professor, Iv. Javakhishvili Tbilisi State University \\ ${ }^{3}$ Doctor of Chemistry, Sokhumi State University \\ ${ }^{4}$ Master of Chemistry, science worker, Laboratory of Analytical Chemistry and Mineral Enrichment, Tbilisi g. \\ Tsulukidze Mining Institute \\ E-mails: ${ }^{1}$.tabatadze@ $@$ sou.edu.ge; ${ }^{2}$ neli.sidamonidze@ $@$ tsu.ge; ${ }^{1}$ darejangulbani67@gmail.com; \\ ${ }^{3}$ dareiremashvili@gmail.com
}

\section{A B S T R A C T}

Reaction reactions of monosaccharides, namely galactose allyl derivatives, with ethyl ether of 2bromo propionic acid have been studied. The study of the alleged biological activity of the synthesized substances was carried out using the PASS Onlaine computer program. Evaluation of the structure-bioactivity revealed the synthesized $\beta-O-(2,3,4,6$-tetra-O-acetyl-Dgalactopyranosyl)-2-methyl-4-bromo pentanoate in the biological activity spectrum of bromo ethylvalerate $\left[-\mathrm{CH}_{2}-\mathrm{CH}(\mathrm{Br})-\mathrm{CH}_{2}-\mathrm{CH}\left(\mathrm{CH}_{3}\right)-\mathrm{COOC}_{2} \mathrm{H}_{5}\right]$ the influence of the group.

Keywords: Bromo propionic acid ether, D-galactopyranosyl, $\beta$-Acetylated products, Bromo pentanoate, PASS Onlaine, bromo glycosides.

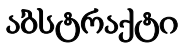

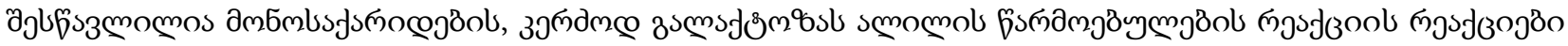

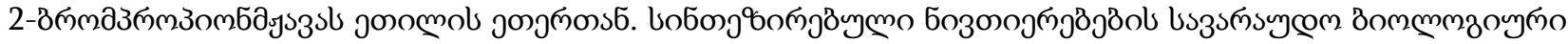

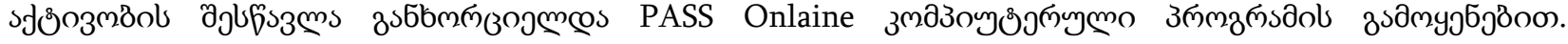

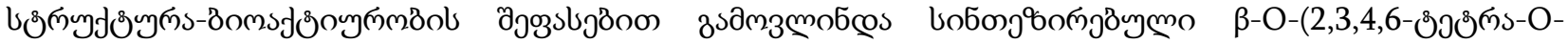

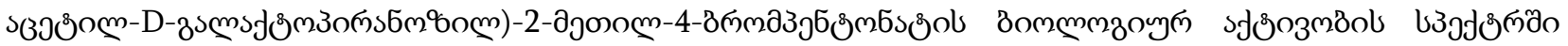

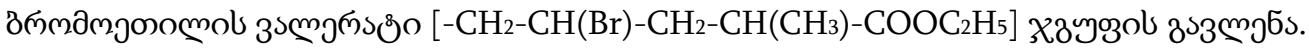

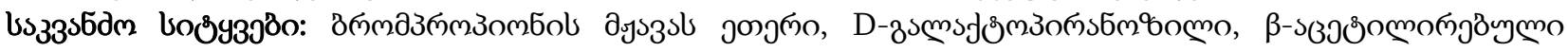

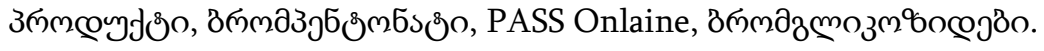

Introduction: Carbohydrate derivatives are widely used in medicine and agriculture. Carbohydrate-based synthesized substances, with their ability to permeate membrane tissue and activate reserve mechanisms, enhance the resistance of living cells to outside factors and diseases, enabling the production of environmentally friendly products. By "inserting" carbohydrate molecules, insoluble drugs are dissolved in water and easily absorbed by the body, significantly reducing their toxicity, which significantly increases the effectiveness of drugs.

Analysis of the scientific literature in recent years shows that the interest of chemical researchers in the synthesis of products containing bromides, has increased dramatically [1-2]. Studies in this area are expected to lead to the development of new, less toxic, biologically and physiologically active drugs. 
The therapeutic effect of glycosides on tissue cells is mainly due to aglycones. The presence of sugar residues helps to improve their solubility, reduce toxicity, permeability to biological membranes, thus creating favorable conditions for reducing the active concentration of some potent pharmacological agents and increasing the range of therapeutic action. The project will synthesize physiologically and biologically active derivatives of bromine [3-4].

Brominated compounds have a special place among pharmaceutical preparations to their resemblance to bromine ethylvalerate. They are Widely used in the production of medicinal (antidepressant, anti-inflammatory, antisclerotic action) drugs [5]. They are tranquilizers, used in bronchial asthma, pneumonia.

It can be assumed that the ability of nucleophilic substitution of bromine atoms makes possible the presence of bromine containing glycosides: $\beta$ - $O$-(2,3,4,6-tetra-O-acetyl-D-galactopy-ranosyl)2-methyl-4-bromo pentanoate (3), which have a wide range of biological activity (antitumor, antibacterial) and are reagents suitable for organic synthesis.

Experimental Part: The allyl derivative of galactose was reacted with ethyl 2-bromo propionic acid. Initially, in the presence of acetic anhydride and sodium acetate on galactose, a $\beta$-acetylated product was obtained: 1,2,3,4,6-penta-O-acetyl- $\beta$ - $D$-galactopyranose (1). Allyl-2,3,4,6-tetra-Oacetyl- $\beta$ - $D$-galactopyranose (2) was synthesized on the $\beta$-acetylated product by the action of allyl alcohol in dichloroethane in the presence of the $\mathrm{BF}_{3}\left[\left(\mathrm{C}_{2} \mathrm{H}_{5}\right)_{2} \mathrm{O}\right]$ catalyst. By dissolving allylated monosaccharides in 2-bromo propionic acid in ethyl ether and adding dropwise a solution of benzoyl peroxide (dissolved in 2-bromo propionic acid in ethyl ether) with constant stirring in a nitrogen atmosphere, a new substance was synthesized: $\beta$-O-(2,3,4)-O-acetyl-Dgalactopyranosyl)-2-methyl-4-bromo pentanoate in a yield of $0.7 \mathrm{~g}(50 \%)$ (3):

The synthesized compounds are white, very soluble in chloroform. The composition of the derivative was determined by physico-chemical research methods [6].

Composition of compounds, physical and chemical characteristics will be determined by instrumental research methods (elemental, polarimetric, chromatographic analyzes, the so-called BMR ${ }^{13} \mathrm{C}$ and BMR $1 \mathrm{H}$ spectroscopy. The definition of optical rotation using elemental analysis, IR and ${ }^{13} \mathrm{C}$ Spectroscopy. The purity of thesubstance as checked using thinlayer chromatography using "silufol" plate in the following solvent system by volume: chloroform-ethanol 1:1. Optical rotation was measured on a SU-3 universal saccharimeter at $20{ }^{\circ} \mathrm{C}$. IR spectra of the samples were taken on a UR-20 spectrometer in KBr tablets. ${ }^{13} \mathrm{C}$ NMR was recorded on a Bruker AM-300,75.5 $\mathrm{MHz}$ spectrometer in deuterochloroforme:

In the infrared spectrum of the synthesized products, no absorption band characteristic for the allyl group is observed in the $1643-1660 \mathrm{~cm}^{-1}$ area and the following absorption bands are formed: 1041.4; A characteristic stripe (C-O-C) for the bond is observed in the area of $1241.9 \mathrm{~cm}^{-1} ; 516.8$ $601.7 \mathrm{~cm}^{-1}(\mathrm{C}-\mathrm{Br}) ; 3463.7 \mathrm{~cm}^{-1}\left(\mathrm{C}-\mathrm{CH}_{3}\right) ; 2923.7 \mathrm{~cm}^{-1} \mathrm{CH}_{2} ; 3471 \mathrm{~cm}^{-1} \mathrm{CH}_{3}$

BMR ${ }^{13} \mathrm{C}(\delta$, M.N.); 100.8 (C-1); 61.8 (C-6); 168.7-170.4 (RO-CO-CH $)$; $72.6\left(\mathrm{RO}_{-} \mathrm{CH}_{2}-\mathrm{CHBr}-\right)$; $39.4\left(\mathrm{RO}-\mathrm{CH}_{2}-\mathrm{CHBr}-\right) ; 41.8\left(\mathrm{RO}-\mathrm{CH}_{2}-\mathrm{CHBr}_{-} \mathrm{CH}_{2}\right) ; 54.8\left(\left(\mathrm{RO}-\mathrm{CH}_{2}-\mathrm{CHBr}-\mathrm{CH}_{2}-\mathrm{CH}-\mathrm{CH}_{3}\right) ; 27.2\right.$ ($\left.\mathrm{C}_{2} \mathrm{H}_{5}\right) ; 38.3\left(-\mathrm{CH}_{3}\right) ; 20.5-20.6\left(\mathrm{RO}-\mathrm{CO}-\mathrm{CH}_{3}\right)$.

This substance has a wide range of predicted biological activities. Prediction of the biological activity of the synthesized carbohydrate product: $\beta-O-(2,3,4)-\mathrm{O}$-acetyl-D-galactopyranosyl)-2methyl-4-bromo pentanoate and free hydroxyl-containing $\beta$ - $D$-galactopyranosyl-2-methyl-4bromo pentanoate was performed using the PASS (Prediction of Activity Spectra for Substance) ONLAINE computer program [8]. 

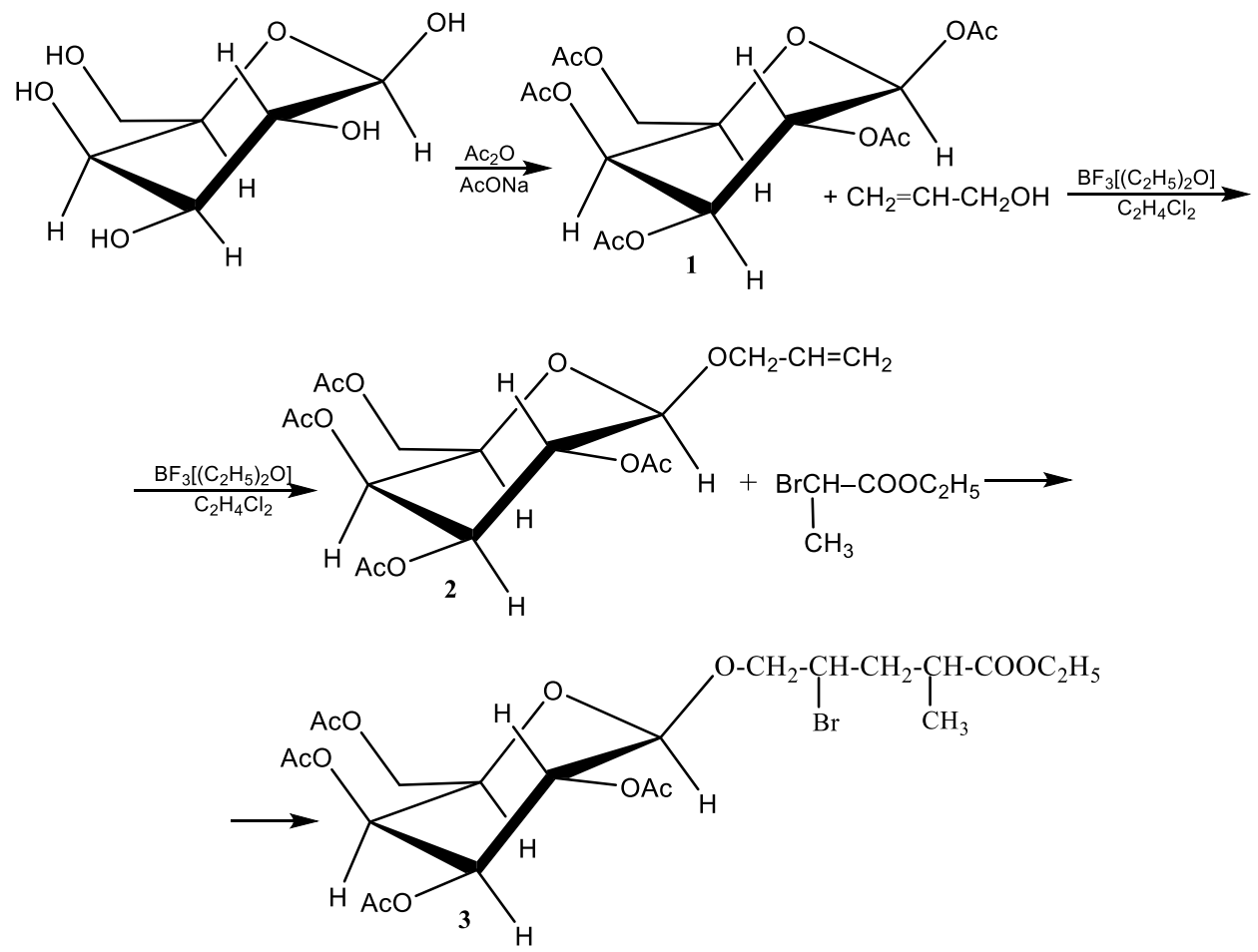

The Biological Activity Spectrum of a chemical compound is the set of different types of biological activity that reflect the results of the compound's interaction with various biological entities. Biological activity is defined qualitatively ("yes"/"none") suggesting that the biological activity spectrum represents the "intrinsic" property of a substance depending only on its structure and physical-chemical characteristics. Though this may be a generalization, it provides the possibility for combining information from many different sources in the same training set, which is necessary because no one particular publication comprehensively covers all the various facets of the biological action of a compound.

The specified computer program evaluated the biological activity of $\beta-\mathrm{O}-(2,3,4)-\mathrm{O}$-acetyl-Dgalactopyranosyl)-2-methyl-4-bromo pentanoate (3) (tab. 1) and his deacetylated product $\beta-D$ galactopyranosyl-2-methyl-4-bromo pentanoate (4) (tab. 2).

$\beta$-O-(2, 3, 4)-O-acetyl-D-galactopyranosyl)-2-methyl -4-bromo pentanoate (3)

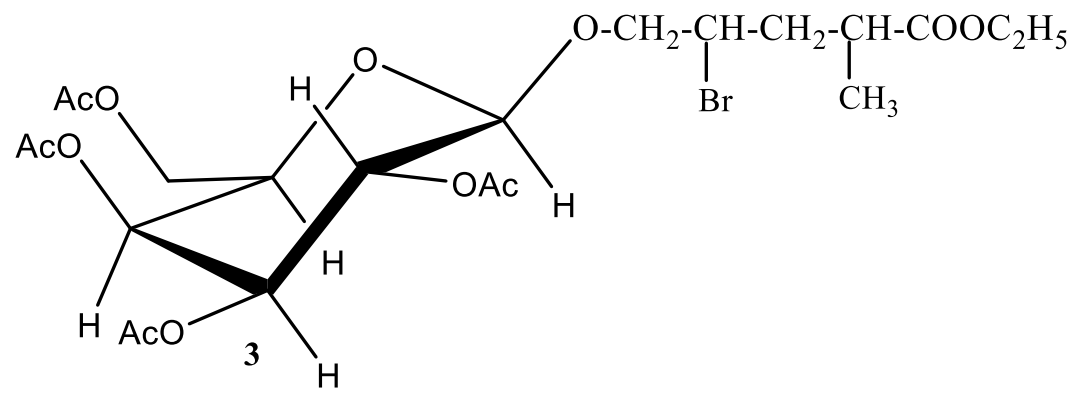




\section{Tab.1}

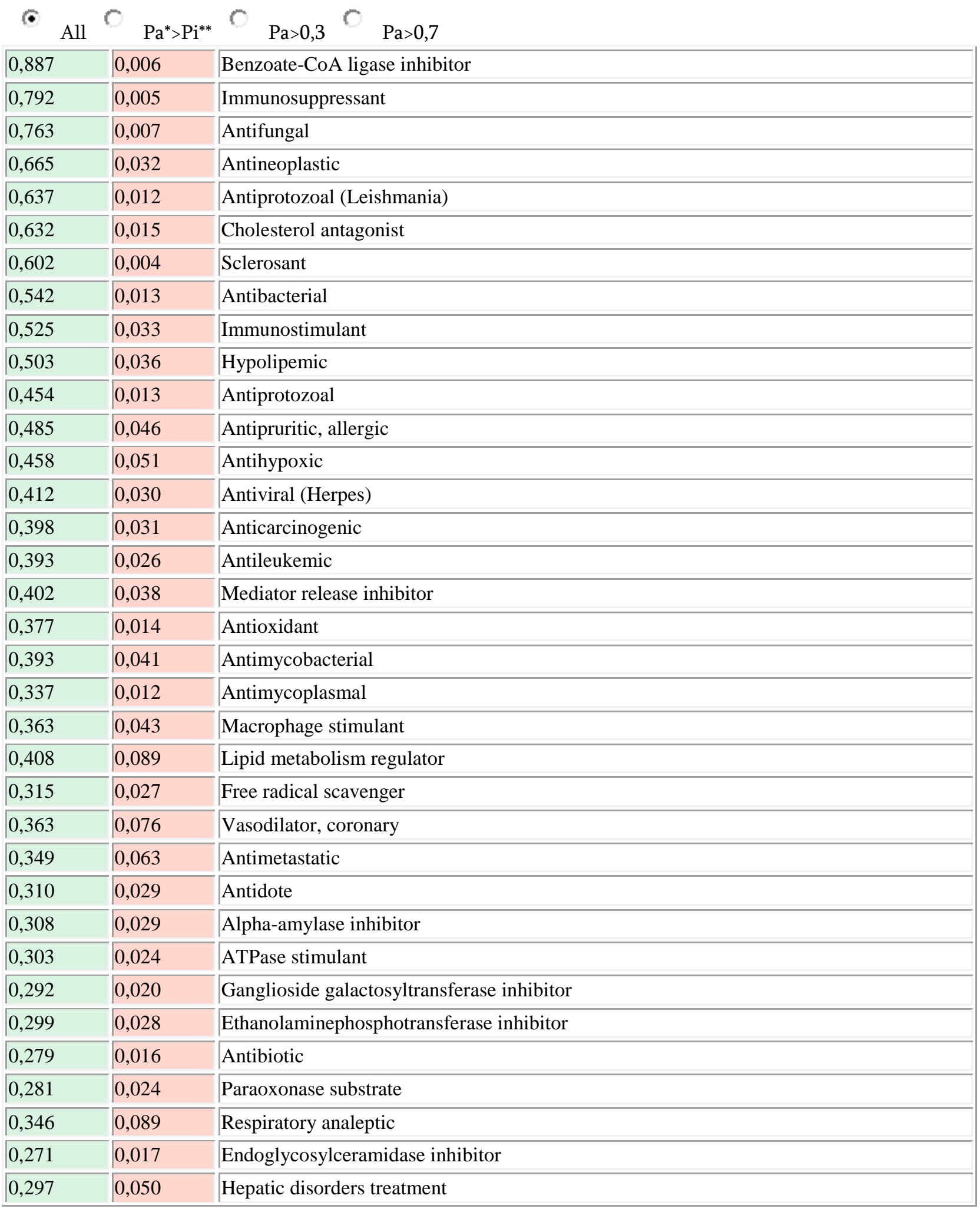


JOURNAL OF SOCIAL RESEARCH \& BEHAVIORAL SCIENCES

\begin{tabular}{|l|l|l|}
\hline 0,327 & 0,082 & Antiinfective \\
\hline 0,382 & 0,148 & Membrane integrity agonist \\
\hline 0,257 & 0,031 & 1,4-Alpha-glucan branching enzyme inhibitor \\
\hline 0,294 & 0,074 & Immunomodulator \\
\hline 0,243 & 0,027 & Microtubule formation inhibitor \\
\hline 0,219 & 0,017 & Thromboxane synthase stimulant \\
\hline 0,207 & 0,006 & Reductase inhibitor \\
\hline 0,229 & 0,050 & Mucorpepsin inhibitor \\
\hline 0,299 & 0,130 & Beta-adrenergic receptor kinase inhibitor \\
\hline
\end{tabular}

Biological activity of deacetylated product $\beta$-D-galactopyranosyl-2-methyl-4-bromo pentanoate (4)

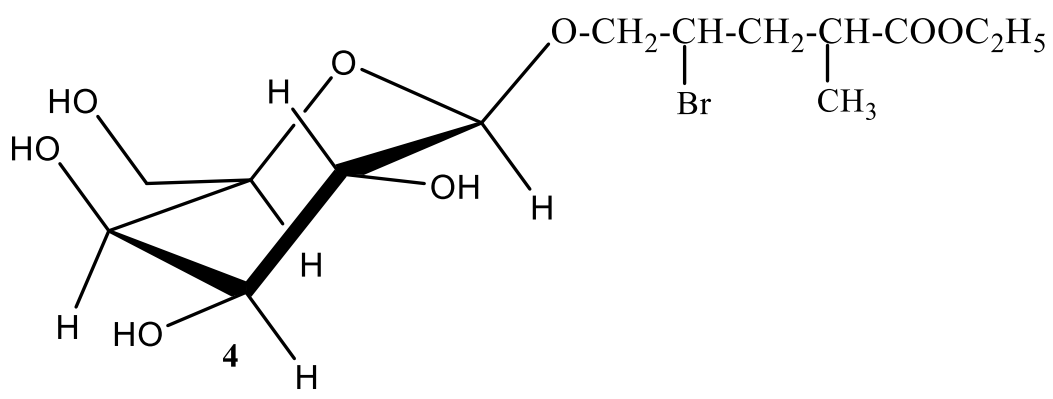

Tab.2.

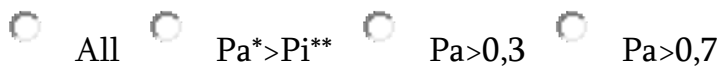

\begin{tabular}{|l|l|l|l|l|}
\hline 0,948 & 0,003 & Benzoate-CoA ligase inhibitor & \\
\hline 0,836 & 0,004 & Cholesterol antagonist & \\
\hline 0,835 & 0,010 & Beta-adrenergic receptor kinase inhibitor & \\
\hline 0,812 & 0,004 & Antihypoxic & \\
\hline 0,794 & 0,002 & Sclerosant & \\
\hline 0,759 & 0,010 & Immunosuppressant & \\
\hline 0,744 & 0,008 & Antifungal & \\
\hline 0,701 & 0,002 & 1,4-Alpha-glucan branching enzyme inhibitor & \\
\hline 0,692 & 0,002 & Alpha-amylase inhibitor & \\
\hline 0,684 & 0,016 & Immunostimulant & \\
\hline 0,646 & 0,010 & Antiinfective & \\
\hline 0,634 & 0,002 & Ganglioside galactosyltransferase inhibitor & \\
\hline 0,627 & 0,004 & Ethanolaminephosphotransferase inhibitor & \\
\hline
\end{tabular}




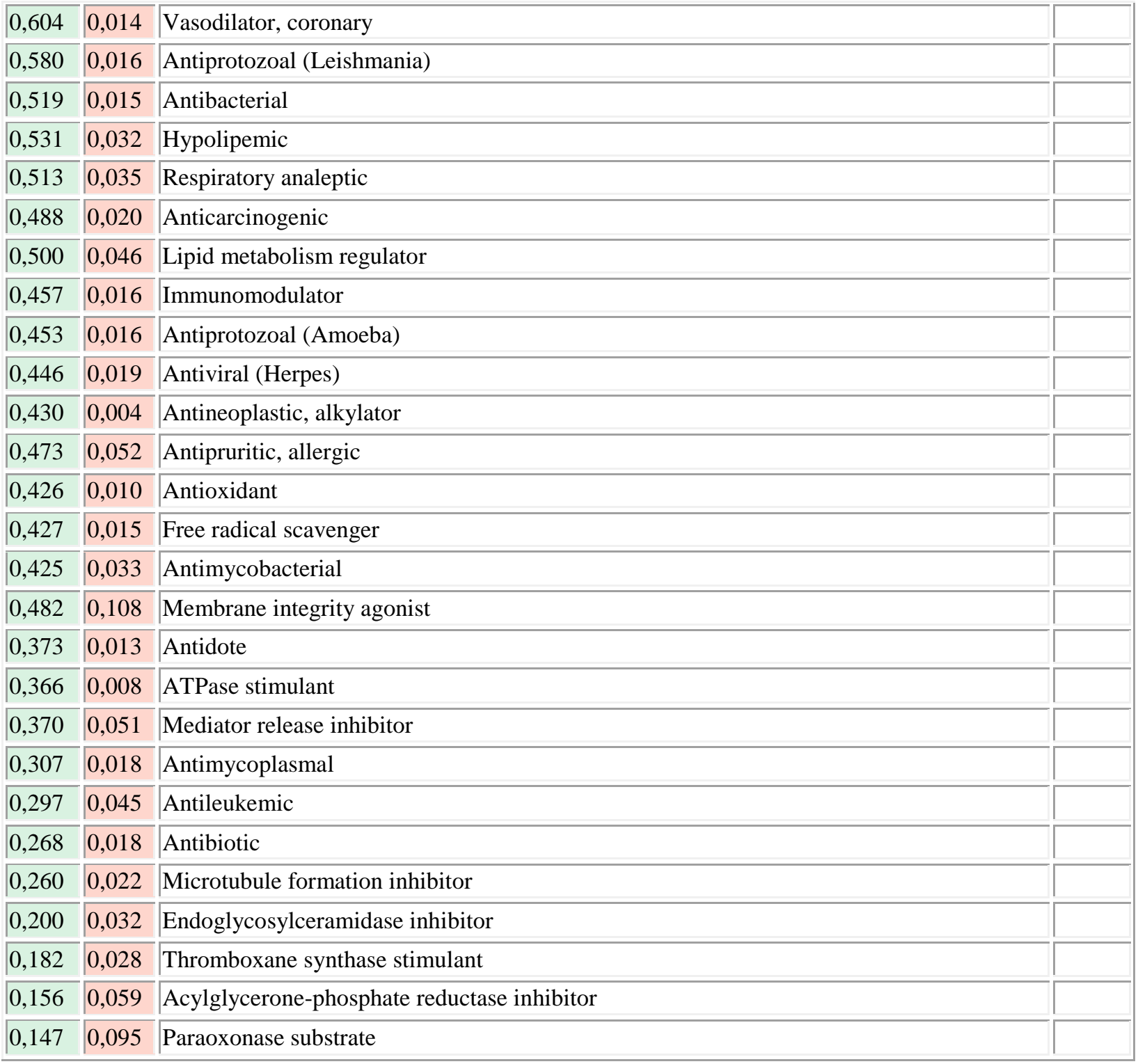

A comparison of the PASS predictions data showed, that similar biological activities: BenzoateCoA ligase inhibitor, Beta-adrenergic receptor kinase inhibitor, Antihypoxic, Sclerosant, Immunosuppressant, 1,4-Alpha-glucan branching enzyme inhibitor, Alpha-amylase inhibitor, Ganglioside galactosyltransferase inhibitor, Vasodilator, coronary, Respiratory analeptic,

Immunostimulant - compound-4 has with higher $\mathrm{Pa}$ value than substance-3 and biological activity: Antifungal, Thromboxane synthase stimulant, Antileukemic, Antibiotic, relatively low Pa.

Based on a generalization of a vast literary material, biologically active compounds are characterized by a certain specificity of composition and structure. Structural modification of compounds by introducing various molecules or atomic groups in a molecule can determine the effect of molecular separation of fragments on bioactivity. 


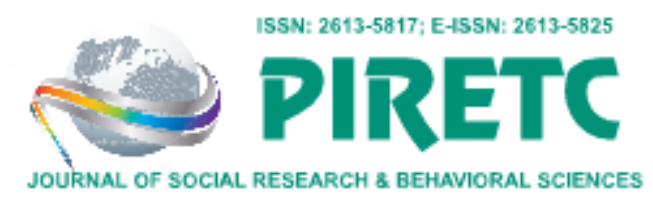

VOLUME 17 ISSUE 072021

$* \mathrm{~Pa}$ (probability "to be active") estimates the chance that the studied compound is belonging to the sub-class of active compounds.

$* * \mathrm{Pi}$ (probability "to be inactive") estimates the chance that the studied compound is belonging to the sub-class of inactive compounds.

Conclusion: A biologically active compound was synthesized on the basis of carbohydrates. For the synthesis of bromine containing sugars, the reactions of allyl derivatives of monosaccharides with ethyl ester of 2-bromo propionic acid were studied.

By inserting a virtual molecule of test compounds into the PASS program, Onlaine has identified a broad spectrum of biological activity. By assessment of structure-bioactivity relationships biological activity spectrum of synthesized glycosides have been revealed. The results of the study will enable us providing selection of the most prospective compounds from the set of synthesized samples.

\section{REFERENCES}

1. Robert J. Ferrier; Radical-Mediated Brominations at Ring Positions of Carbohydrates January, Advances in Carbohydrate Chemistry and Biochemistry 2010, 49(3):37-92.

2. Cuiwen He, Wenxin Song, Thomas A. Weston, Caitlyn Tran, Ira Kurtz, eJonathan E. Zuckerman, Paul Guagliardo, Jeffrey H. Miner, Sergey V. Ivanov, Jeremy Bougoure, Billy G. Hudson, Selene Colon, Paul A. Voziyan, Gautam Bhave, Loren G. Fong, Stephen G. Young, and Haibo Jiang; Peroxidasin-mediated bromine enrichment of basement membranes; PNAS-Proceedingsof the National Academy of Scieces of the United States of America; July 7, 2020, 117 (27): 15827-15836. https://doi.org/10.1073/pnas.2007749117.

3. Patel, D.R./Patel, A.L./Patel, B.M./Patel, K.C. Synthesis of some New Bromine Containing Reactive Dyes: Their Applications and Microbial Studies; International Journal of Chemical Sciences; 2010, 8(1): 235-248. ISSN: 0972-768X.

4. Meermann B, Bockx M, Laenen A, Van Looveren C, Cuyckens F, Vanhaecke F; Speciation analysis of bromine-containing drug metabolites in feces samples from a human in vivo study by means of HPLC/ICP-MS combined with on-line isotope dilution. Analytical and Bioanalytical Chemistry, 2011, 402(1):439-448. DOI:10.1007/00216-0115339-y.

5. Seda Cantekin, Arif Baran, Raşit Calişkan, Metin Balci; Synthesis of bromo-conduritol-B and bromo-conduritol-C as glycosidase inhibitors. Carbohydr Res. 2009 Mar 10; 344(4):426-31. doi: 10.1016/j.carres.2008.

6. Tabatadze L.V., Gakhokidze R.A., Tatarishvili M.Z. Synthesis of Some Brominecontaining Monosaccharides. Georgian Chemical Journal, 2006, V.6, 15, 511-512. (in Russian).

7. Gakhokidze R.A., Sidamonidze N.N., Tabatadze L.V., Tatarishvili M.Z. Antimicrobial Activity of Bromine-containing Disaccharides. Georgian Engineering News, 2006. 11, 258-260. (in Russian).

8. L.V. Tabatadze, N.N. Sidamonidze, D.J. Iremashvili; Synthesis, Research and Biological activity of Hepta-O-acetyl-1-O-(2-chloro-3-phenyl thio propyl)- $\beta$-D-lactose. Chapter from the book, V.1. <Chemical and Technological Aspects of Biopolymers>. Tbilisi. 2020. P. 18-26. ISBN 978-9941-25-790-2; www.Elibrary.sou.edu.ge 


\title{
KARABAKH'S TOURISM PROSPECTS AS A KEY FACTOR IN THE DEVELOPMENT OF THE NATIONAL ECONOMY
}

Konul Valiyeva

Azerbaijan State Economic University, Azerbaijan.

Email: konul.veliyeva97@gmail.com

\begin{abstract}
In the modern world, tourism is perceived as a socio-economic event that directly and indirectly affects the development of all related infrastructure. Modern tourism is based on a high level of development of transport, social and service sectors, which ultimately makes it a highly profitable sector of the economy. According to the World Tourism Organization (WTO), tourism is one of the most profitable and dynamic sectors of the world economy today. It is the second most profitable after oil production and refining. Tourism accounts for about $6 \%$ of the world's gross domestic product, $7 \%$ of global investment, every 16th job, $11 \%$ of global consumption spending and $5 \%$ of all tax revenues. In this regard, the tourism sector is actively developing in many countries with state support. The main purpose of the study is to analyze the prospects for the development of tourism in Karabakh.

Nagorno-Karabakh has great tourism potential, and the restoration of lost infrastructure communications in the liberated territories is expected to create favorable conditions for business, including the development of tourism. The article discusses the features of tourism in Karabakh, the concept of tourism development prospects, as well as its problems.
\end{abstract}

Keyword: Karabakh, tourism, development, economy, prospects

Introduction: There are great opportunities for the development of many types of tourism in Karabakh - eco, mountain, winter, hunting, health tourism. This region of Azerbaijan with an ancient history, unique flora and fauna, cuisine, historical, cultural and religious monuments, ancient castles, bridges, forests, springs, etc. will attract tourists with its sights. It is possible to organize various types of extreme tourism, agrotourism, green tourism in Karabakh, which has rich natural resources. All this creates great prospects for the development of tourism. It is important to build tourism infrastructure in the form of interaction in our liberated territories. Shusha will be one of the symbolic cities of Azerbaijani tourism. The historical monuments and unique architecture of Shusha, the pearl of Azerbaijani culture, will allow the creation of new tourist routes. The climate of Shusha is temperate, and mineral waters have healing properties. These are also very useful places for tourism. Well-known composers, mugam masters and artists grew up here.

Infrastructure construction has already begun in our liberated lands: At the same time, the article discusses the work to raise awareness of Karabakh's tourism potential to the world and preliminary research to take advantage of the region's tourism opportunities, the positive impact of the development of the tourism sector in Karabakh on the region's rapid economic recovery. At the end of the Patriotic War, which ended with the complete victory of Azerbaijan on November 10, the future prospects of economic and cultural development in Karabakh remain on 
the agenda. The Republic of Azerbaijan intends to restore Karabakh and surrounding areas, build modern infrastructure, increase tourism opportunities in the region, etc. targeted.

The victory of Azerbaijan also showed the creative determination of our people. Restoration of important state structures in the liberated regions, involvement of tourism and hydropower in Sugovushan, road infrastructure works in these areas, use of Khudafer reservoirs for hydropower and land reclamation are on the agenda as purely economic measures. The revival of the region's economy after the complete withdrawal of the enemy from Karabakh suggests that in the near future this country will once again become a thriving cultural center of the entire South Caucasus, a popular tourist destination.

Karabakh and seven other regions liberated from Armenian occupation have historically had integrative relations with other regions of the country in terms of economic development within the independent Republic of Azerbaijan. Thirty years ago, the region's geographical location, natural resources and human resources played an important role in the development of the Karabakh economy. Along with the transport and infrastructure conditions created during that period, the existing natural resources allowed the implementation of important projects in the fields of energy, mining, and agriculture, processing industry, forestry, fisheries and tourism. Until 1988, the collapse of the USSR, the Nagorno-Karabakh economic region achieved significant development due to these resources, and these economic results were directly reflected in the living standards and employment of the population living in the region. If we look at the statistics of that period, we can see that the republic has achieved serious results in the production of a number of products. Thus, if we look only at agriculture, we can see that along with grain, vegetables, fruit, viticulture, cotton and tobacco, important indicators have been achieved in the production of meat and dairy products. Historically, the types of occupations and experience gained by the Karabakh people have played a key role here. Also, the name of Karabakh has become a world brand in the processing industry and crafts, especially in the world-famous carpet weaving. Along with all these and other areas, Karabakh has been in the spotlight of tourists with its unique tourism resources and resorts, protected nature and recreation areas.

Karabakh, with its breathtaking views, magnificent mountains, lakes, valleys and plains, has an ancient history and cultural heritage, as well as a rich tourism potential. The city of Shusha is the cultural capital and cradle of culture of the region, located on a picturesque hill. Travelers visiting Azerbaijan in ancient and especially the Middle Ages spoke about the beauty of this land, its unique natural, historical and cultural riches. Starting from the second half of the 19th century, foreign capitalists who came to Azerbaijan for oil visited Karabakh, one of the most beautiful places in the South Caucasus - Shusha and Kalbajar. Later, during the Soviet era, Karabakh was very popular with both foreign and local tourists. Since the 30s of the XX century, resorts, boarding houses, sanatoriums in Shusha, Turshsu pastures, Sakili spring, Isa spring, the legendary Cidir plain have become a favorite place of visitors. At the same time, the tourism and recreation potential of the region's Khankendi, Agdam and Kalbajar regions is internationally recognized, and a significant part of the hundreds of thousands of tourists visiting our country fell to Karabakh. In particular, since the 1970s, hundreds of thousands of local and foreign tourists use the services of tourism and recreation facilities established here every year. However, as a result of the Armenian military aggression since 1988, the placement of refugees not only in Karabakh, but also in the country's resorts and sanatoriums has seriously damaged domestic and inbound tourism, looted tourism resources, especially Azerbaijan's rich historical and cultural heritage. There is an ecological crisis in the region, all the infrastructure has been destroyed. [1] 
The visits of Karabakh people, their close relatives, representatives of international organizations carrying out various humanitarian missions, the media army from all over the world and investors coming to Azerbaijan to invest in the region will be accompanied by other activities. As for the types of tourism, November 8 - the liberation of Shusha from occupation will be of special importance in terms of historical tourism. On this historic day, people of all ages and social groups participating in the tours will travel the path of victory of the Azerbaijani Army as tourists this time. For those making their first visit to Shusha, especially for foreign media, such visits will be a special opportunity to show the true nature of Armenian vandalism. The main motive of such tours will be to show to all mankind the primitive Armenian way of life, reminiscent of the human settlements destroyed during the 30-year occupation of Karabakh, damaged ecosystems, destroyed graves, as well as the Stone Age. These routes will have a very rich information resource from Sugovushan to Khankendi, from Jabrayil to Kalbajar, which was liberated from the first occupation. When foreign journalists, as well as all foreign tourists, see the cities and villages inherited from the occupation, they will get the most realistic picture of the real lifestyle of Armenians. Then the whole world will know that these fascists are ready to leave such traces at any time in Los Angeles, Marseille, Beirut and Rostov.

The development of tourism in post-occupation Karabakh will be one of the most important factors for the revival of the region's economy and the return of the local population to other parts of the country. The very serious socio-humanitarian functions of tourism allow us to do this. This will lead to an influx of labor into the region, as the services offered to tourists will be completed faster than in other areas. Due to the wide range of opportunities for medical tourism and ecotourism in Karabakh, the range and content of services offered to tourists will be wide. Watching the Shusha orchid plant, which is very popular in the world in terms of tourist interest, live in Shusha, especially increases the tourist attractiveness of Karabakh. Unlike many parts of Azerbaijan, the Karabakh region is rich in greenery and has mild winters and summers. After the Armenian occupation, the rapid renewal of rural infrastructure and the creation of all conditions for normal life will make the villages of the region a favorite place for urban tourists. [2]

Along with the multiplier effect on the economy, the future development of tourism in Karabakh is of great political importance. All this means that the image of a risky region created by Armenians for 30 years, not only for this region, but for the entire South Caucasus, is being destroyed. The concept of a risky region in connection with the occupation of Karabakh has seriously damaged not only our country, but also the entire region, both inbound and outbound tourism. Today, the defeated Armenian society, which does not give up its crazy dreams and is greedy for a piece of dry wood, should know that we also had very valuable tourism resources, such as Azerbaijani gold, forest resources, looted construction materials. in occupied Karabakh. Therefore, the positive results that Azerbaijan will get from Karabakh tourism in the short term will be a more convincing argument for the material compensation that Armenia must pay for the damage to our country's tourism resources, tourism industry and our economy in general. According to the results of 2019, about 2.5 million foreign tourists visiting Azerbaijan bring about $\$ 3$ billion to the country's economy, which is the level of income we lost as a result of the occupation of Karabakh.

Tourism is not only the fruit of peace and stability, but also an important factor in a comfortable life. Therefore, if the liberation of Karabakh goes down in history as the first important event of the XXI century, the development of tourism in this country will be an important contribution to the humanitarian development that everyone wants in this region. [5] 
One of the other natural resources of Karabakh is the Istisu mineral water spring and the Istisu resort built on this spring. The Kalbajar region, home to the Georgian resort of Istisu, which left the Shaltuba River behind, was occupied by Armenia in April 1993. Occupying the Istisu resort, Armenia changed the name of the famous medicinal mineral water of the same name and began to sell it to foreign countries under the name "Cermux".

If we look at the history, we can see that although the main tourism potential of Karabakh was concentrated in Shusha and Agdam, all regions of the region were suitable for treatment and recreation. During the Soviet period, tourism potential was developed in Shusha and Aghdam in the 1980s. The first rest house in Shusha was put into operation in 1936. Shusha Sanatorium and Resort Association for 1316 seats in Shusha, "Shafa" tourist base for 130 seats and 100-seat treatment and recreation centers in Gulabli village of Aghdam region, 50-medical shelters in Shelli village and 40-seat medical recreation centers in Shahbulag. Shusha sanatorium-resort association included 17 buildings with 2 and 3 floors.

In addition, the construction of another sanatorium for 200 beds in Shusha and 255 beds in Agdam in the 1980s was not commissioned due to the conflict. The Shusha sanatorium-resort association also had a 28-bed residential complex for employees. In addition, there were summer camps for schoolchildren in the city. Two of them served at the national level for 500 and 300 seats, and the other served the students of the region.

Earlier, 14 cottages and 4 Kyrgyz tents were built in the area. The sanatorium, which is planned to operate throughout the year, also had a treatment building. The establishment of auxiliary farms in the sanatorium has provided visitors with high-quality food products and additional income. One of the interesting facts is that tourists are taken for a walk on the Karabakh horse presented to the enterprise. By the way, it should be noted that tourists were offered to ride horses at the Shahbulag tourist base. Shahbulag tourist base, which receives 40 tourists, was put into operation in 1988. Gulabli sanatorium is currently on the balance of the Union of Collective Farms of Azerbaijan.

Conclusion: It is clear that the occupation of Karabakh and surrounding areas by the Armenian armed forces, among other things, has seriously damaged the region's tourism economy. Measures have already been taken for the reconstruction and sustainable development of Karabakh. According to the State Tourism Agency, work has already begun to study the tourism potential of the Karabakh region. Currently, demining works are underway. Infrastructure work must be done. Today, it is too early to talk about organizing any tour to the region. This work must be done first. Most importantly, the condition of historical and architectural monuments should be studied. They need to be reconsidered. Although a number of scientists have studied the historical monuments in Karabakh, 30 years have passed. Of course, they need to be reconsidered. Which monuments should be taken under state protection? They need to be restored. It is necessary to build sidewalks, draw and mark sidewalks. Preparation of tourist maps and other work should be done. We will be able to cope with this in the coming years. This work should be carried out by a number of departments, ministries and agencies. There are issues that need to be addressed by various institutions and institutions.

In general, Karabakh will become a new tourist destination for us. Not only a few regions, but the entire territory of Karabakh will become a new tourist destination. It is necessary to ensure the security of these areas. Travel there must be safe for tourists. I hope that all scientists will jointly analyze the territory of Karabakh, create new tourist routes and tourism products. After the crisis 
in the tourism sector is over, we will attract more tourists by selling these products. Special new types of tourism will appear. I am confident that Karabakh will become an ecological tourism area and will be recognized as a regional area for ecological tourism. The time will come when we will create more beautiful places in Karabakh and adjacent regions than the resorts in the Swiss Alps, resorts in France, Italy and Germany.

The development of tourism in the Karabakh region will be of great benefit to our country.

\section{REFERENCES}

1. Aghayeva Khanim Yusif, Hatamova Turkan Mashallah, Sheydai Turkan Ali, "Defining directions of economic development policy of Karabakh region”, Scientific Collection «Interconf»| № 66, page 17-22

2. Leyla Huseynova, Mehriban Aliyeva, "Econometric analysis of perspectives that opens up growth of tourism in region after liberation of Karabakh", 70th International Scientific Conference on Economic and Social Development - Baku, 25-26 June, 2021, page 855864

3. Saadat Gandilova, Features and prospects of development of tourism in Karabakh, 70th International Scientific Conference on Economic and Social Development - Baku, 25-26 June, 2021, page 1093-1099

4. Seymur Latif oglu Hasanov, Elnur Latif oglu Hasanov, "Applied features of comparative technical, sociological investigation of historical and contemporary heritage of Azerbaijan", Year: 2018 Issue: 01 Volume: 57

5. Shafa Guliyeva, "Economic prospects for the growth of Azerbaijan non-oil sector in the liberated territories of the Republic", 70th International Scientific Conference on Economic and Social Development - Baku, 25-26 June, 2021, page 360-365

6. Yusif Musayev, "Development of family businesses in Karabakh region of Azerbaijan: New opportunities and prospects", 70th International Scientific Conference on Economic and Social Development - Baku, 25-26 June, 2021, page 449-458

7. İqtisadi İslahatların Təhlili və Kommunikasiya Mərkəzi | Ereforms.gov.az

8. Туризм в условиях новой реальности | The M.O.S.T. (themost.az)

9. Javid Seyidov, Roma Adomaitienè, Factors influencing local tourists' decision-making on choosing a destination: a case of Azerbaijan, . Ekonomika 2016 Vol. 95(3), Faculty of economics, Vilnius University, page 112-127

10. https://www.stat.gov.az/source/tourism/

11. State Tourism Agency of the Republic of Azerbaijan web site, About tourism in Azerbaijan, Retrieved from : https://tourism.gov.az/

12. World Travel \& Tourism Council (2021). Travel \& Tourism: Economic Impact 2021, Azerbaijan 2021 Annual Research: Key Highlights, Retrieved from https://wttc.org/Research/Economic-Impact 17

13. Qadir Bayramli, "Azərbaycanda turizmin dayanıqli inkişaf perspektivləri”, Sustainable Development and Actual Problems of Humanitarian Sciences: 14-15 May, 2018, page 4042 


\title{
ISSUES OF INTEGRATION INTO THE GREEN ECONOMY IN THE REPUBLIC OF AZERBAIJAN
}

\section{Orkhan Hajizada}

Azerbaijan State University of Economics

Email: Hacizada.orxan@gmail.com

\begin{abstract}
In recent years, the developed countries of the world are building their policies to ensure more sustainable development. The main goal of sustainable development, which is a model of economic development, is to ensure that available resources are used for human needs while protecting the environment. Thus, when using these resources, not only the current situation, but also the potential needs of future generations must be considered. Given the demand for energy and energy resources in modern times, we can see how important a sustainable energy policy is.
\end{abstract}

Keywords: green economy, sustainable development, green policy.

Introduction: The idea of green economy has emerged recently and is soaring into greater prominence through the conference known as Rio+20. To understand it a little better, we must seek the origin of the concept, which is found in the idea of sustainable economic development, also known as sustainable development.

The rapid development of the oil sector since Azerbaijan gained independence has led to an environmental crisis. The end of the oil era and the spread of environmental problems in the country are forcing Azerbaijan to join the phenomenon of "green economy" in the world.

Analysis: According to the classic definition provided in the so-called Brundtland Report, sustainable development is development that "meets the needs of the present without compromising the ability of future generations to meet their own needs" (World Commission ..., 1987).

Behind this concept was the need to rethink economic development under a new perspective, considering the inter-generational equity. Until then, economic development was seen from a slightly narrower perspective that usually considered the fundamental determinants of economic growth, without regard for the environment. These fundamental determinants have ultimately produced changes in the accumulation of factors of production and in productivity (encompassing technological progress and changes in the efficiency with which the factors are used), besides influencing the country's growth rate. Less orthodox currents also have studied problems of income distribution, among others, using a less rigorous formalization. Currently, less orthodox ideas are incorporated into economic models, largely due to the dissemination of more sophisticated mathematical methods in Economics (Krugman, 1995). The empirical analysis of economic growth models has also gained new momentum since the interest in economic growth models was renewed in the mid-1980s.

The relationship between economic development and environment has become more explicit since 1970s, when researchers began to examine what the limits to growth would be in a context where natural resources are finite. At the time, several disturbing forecasts emerged (Meadows et al., 1972), which later were put into perspective, when the analysis began to incorporate a more 
sophisticated modeling method that considered technological progress, the discovery of new reserves of natural resources and the use of reserves that previously had not been economically viable.

The current environmental changes in the world and the geometric series of population growth are leading to a further reduction of limited resources. Therefore, businesses engaged in the supply of basic consumer goods are moving towards new green economy standards, reducing the "carbon footprint" and developing new strategies and mechanisms to increase adaptability, considering the growing consumption and demand of the population. must implement policies.

The government of Azerbaijan is now looking to implement a policy that will bring about the country's transition to a low-carbon, resource efficient and socially inclusive economy.

Two Strategic Road Maps of Azerbaijan approved in late 2016 - on the production and processing of agricultural products and on the production of consumer goods at the level of small and medium enterprises - also reflect the issue of a gradual transition to a 'Green Economy'.

In 2018, Azerbaijan will study the possibility of introducing the principles of the "Green Economy" in agriculture, and after 2025 will begin developing a legal framework for the transition of small and medium-sized businesses to the "green economic model."

Nowadays, Azerbaijan is increasingly proposing to introduce a "green tax" on the utilization of old household appliances and electronics, as well as toughen penalties for environmental pollution.

At the national level, Azerbaijan is in the process of redefining its medium-term development strategy by supporting private sector development and improving the enabling environment. In December 2016, it launched a strategic roadmap for development of the national economy and 11 key sectors, with medium and long-term goals for reforms and sustainable development. There is also a focus on regional connectivity, transit and trade (e.g. Baku-Tbilisi-Kars and the TransAnatolian Natural Gas Pipeline (TANAP) and Trans-Adriatic Pipeline (TAP).

The government of Azerbaijan has prepared several policy documents setting ambitious targets and creating a framework to encourage investment in low-carbon, climate-resilient development.

- Azerbaijan 2020 highlights the possible impact of climate change on the country's society and economy, and the importance of preparing necessary policy measures. It also states that the amounts of energy and $\mathrm{CO} 2$ used to produce one unit of gross domestic product (GDP) should be in line with the appropriate OECD member country benchmarks by 2020 .

- Azerbaijan's Intended Nationally Determined Contribution (INDC) outlines some of the priority sectors in mitigation. These priorities include residential and commercial buildings, fugitive gas from the oil and gas sector, and the transport sector.

- The Strategy of Development of Renewable and Alternative Energy Sources in 2012-2020 aims to increase the share of electricity consumed to $20 \%$ by 2020 , with a total of $9.7 \%$ of total energy consumption to be met by renewable energy sources.

To meet these commitments and ambitious policy targets, Azerbaijan needs policies founded on a good understanding of what determines green growth. This will require appropriate indicators to monitor progress.

Talking about numbers, we can mention that renewable energy accounted for $7 \%$ of total electricity generation in 2015, compared to $6 \%$ in 2013. Wind and solar power generation are relatively new forms of electricity production for Azerbaijan and are on the list of the Government's priorities. 
Since 2000, total investment in this sector by the State Agency for Renewable and Alternative Energy has reached AZN 800 million (AZN 64 million in 2014).6 The rate of development is promising, even though, by comparison to traditional hydropower generation, the numbers are modest.

Figure 1: Renewable energy rates in Azerbaijan

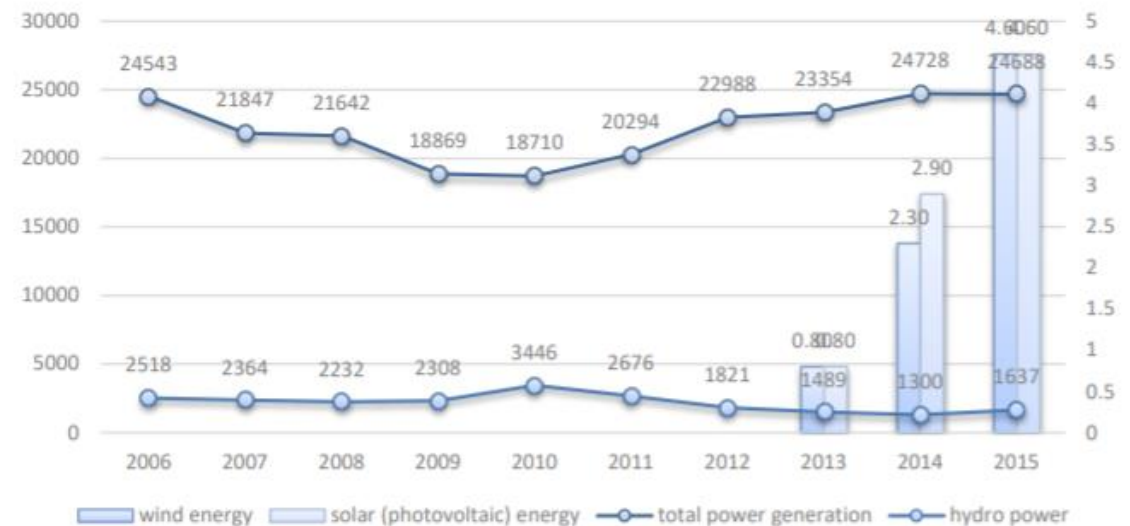

Source: State Committee of Statistics of Azerbaijan, 2016.

Azerbaijan is already making efforts to reduce the negative impact on the environment and the development of "green technologies", including alternative energy sources and related technologies. Spokesman of Minister of Ecology and Natural Resources said that the republic plans to reduce greenhouse gas emissions to the atmosphere by 35 percent and to receive 30 percent of energy from renewable sources until 2030.

Figure 2: Capital investment for environment protection, thousand USD

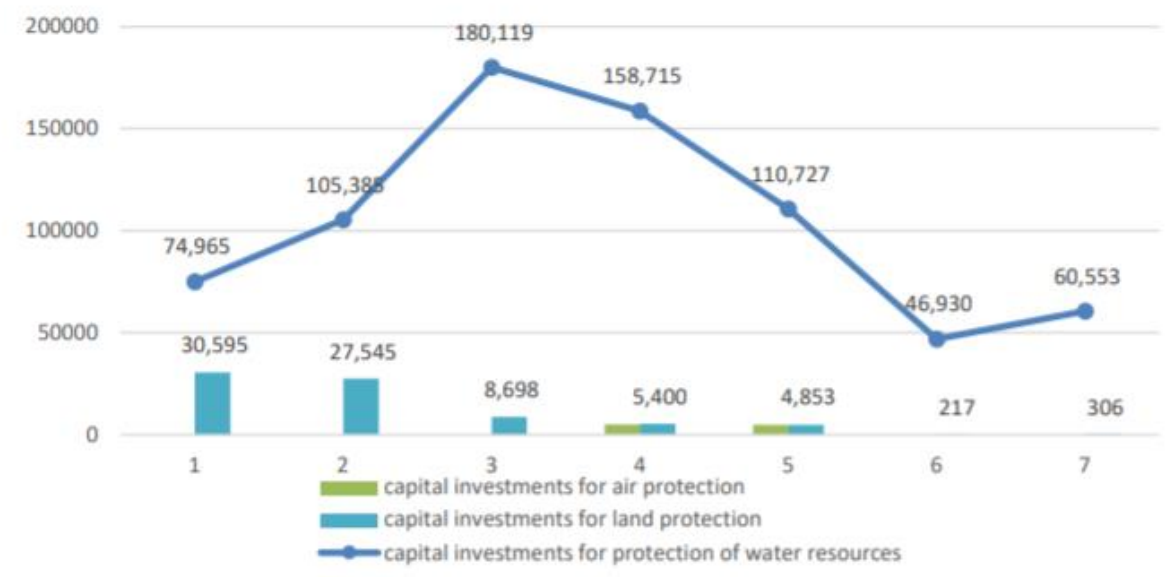

Source: State Committee of Statistics of Azerbaijan, 2017. 
Methods: The main methods to be used in the research process will be correlation-regression, consent-statistical and forecast methods. Thus, research will be carried out in the economy of the Republic of Azerbaijan using methods such as studying the main characteristics of the green economy, studying the source of problems, the causes, and difficulties of solving them.

The main source of research will be public and private structures that include the concept of green economy in Azerbaijan and the world. The main direction in the public sector will be the study of environmental and green policy projects put forward by the Ministry of Agriculture and the Ministry of Ecology and Natural Resources, as well as the return methods of the new "Smart Village" projects in Karabakh and East Zangezur.

In the private sector, companies and enterprises with environmentally friendly projects and "green" business policies in the country and around the world will be investigated.

In addition, SWOT, BCG Matrix analysis and mathematical-statistical methods will be used in the study. At the global and Azerbaijani levels, the term green economy will be researched, evaluated and future forecasts and risk prevention activities will be developed.

Conclusion and Results: Green economy is considered as a future of mankind. Since the crisis of the real economy in 2008, an intense discussion about the need for changes in the economy, supported by several declarations on the global scale, has been developed. The analysis of the causes and effects of the economic downturn and the challenges of the future have had a huge impact on this situation. As a result, some states have taken action to remedy the situation. Many of them were aimed at structural changes in production, consumption, and environmentally friendly investment. At the same time, the concept of "low carbon economy" and "green economy" gained importance. The aim of this research is to present the role of the state in the economy in terms of creating conditions for a green economy.

In Azerbaijan, green economy has a good chance to thrive and develop intensively. The main factors are there is strong political will. It determines that there is wide recognition across the government and among different stakeholders.

Another factor is inter-ministerial co-ordination. Due to strategic vision by state ministries and government organizations work together to hit thresholds.

Also, State policy of Azerbaijan is very vital on this issue. It aims to serve as background and as a starting point for follow-up development of green growth policies in Azerbaijan. It provides a basis for policy makers to assess their decisions.

\section{REFERENCES}

1. Green economy in Azerbaijan - Google Scholar

2. Green economy - Google Scholar

3. Azerbaijan from Inclusive and Innovative Governance to Green Economy. E Ahmadov, T Khalilov, 2009

4. Transition to renewable energy and sustainable energy development in Azerbaijan. $\mathrm{N}$ Vidadili, E Suleymanov, C Bulut, 2017

5. Designing the green economy: The postindustrial alternative to corporate globalization. B Milani, 2000

6. The green economy: Environment, sustainable development and the politics of the future. M. Jacobs, 1993 
7. The Green Economy: Environment: Sustainable Development and the Politics of the Future. C. Schmidt - 1993

8. Ekoloji inqilab: Yaşıl iqtisadiyyat və texnologiyalar - ASA (azescience.org)

9. Azərbaycan respublikasının prezidenti yanında strateji araşdırmalar mərkəzi. Yaşı1 inkişaf: enerji səmərəliliyi və alternativ mənbələr. Bak1 - 2014.

10. Blueprint for a sustainable economy. DW Pearce, E Barbier - 2000

11. Хильчевская Р. И., Сафонов П. И. Проблемы устойчивого развития и экологической экономики и их решение в России (1994)

12. Перелет Р. А., Сафонов П. И. Approaches to Integrated Industrial and Environmental Management for Sustainable Development in Russia, Industry and Environment, UNEP ID Journal, Paris, Volume 18, No.2-3, April-September, pp. 73-77 (1995)

13. Касьянов П. В. Есть ли у нас долгосрочная перспектива? (2000)

14. Гурман В. И., Кульбака Н. Э., Рюмина Е. В. Проблемы учета экологической составляющей в системе национальных счетов //Экономика и математические методы, 1996, т. 32, вып.1., с.111-120.

15. Мельник Л. Г. Экологическая экономика: Учебник для вузов. - Сумы: Университетская книга, 2001. - 350 с.

16. Бизяркина E.H. [https://web.archive.org/web/20130614124058/ http://www.cemi.rssi.ru/mei/authoref/aut-biz-08.pdf Arxivləşdirilib 2013-06-14 at the Wayback Machine Экологически устойчивое социально-экономическое развитие: основы теории и методологии: Автореферат диссертации на соискание учёной степени д. э. н.] // Институт проблем рынка РАН, Москва (2008)

17. Эколого-экономический словарь // Интернет-проект "Роза Ветров" (2000)

18. Экологическая экономика: Учебный курс на базе Нижегородского Государственного Архитектурно-строительного университета (2003)

19. Князева В. П. Экология. Основы реставрации Arxivləşdirilib 2020-11-12 at the Wayback Machine, Москва (2005)

20. Библиография по эколого-экономическим проблемам Arxivləşdirilib 2013-06-14 at the Wayback Machine, Институт проблем рынка РАН (2003)

21. Ekoloji iqtisadiyyat - Vikipediya (wikipedia.org)

22. The Green Economy. J Michael - 1993

23. Green policies and public finance in a small open economy. AL Bovenberg, F van der Ploeg - The Scandinavian Journal of Economics, 1994

24. The changing rules of global competitiveness in the 21st century. SA Zahra - Academy of Management Perspectives, 1999 - journals.aom.org

25. Green economics: Links between environment and economy. R Dransfield - Teaching Business \& Economics, 1998

26. Towards a green economy: the market. R White - Ecopolitics V, 1992

27. Moving to a green economy. P Elkins - Mineral Planning, 1996

28. Green policies in a small open economy. A Bovenberg, F van der Ploeg - 1993 ideas.repec.org

29. Dünyada və Azərbaycanda yeni iqtisadiyyat - yaşıl biznes hərəkatı (bizimyol.info)

30. "United Nations Environment Programme (UNEP)". Archived from the original on 27 March 2016. Retrieved 11 May 2016. 
31. Lynn R. Kahle, Eda Gurel-Atay, Eds (2014). Communicating Sustainability for the Green Economy. New York: M.E. Sharpe. ISBN 978-0-7656-3680-5.

32. UNEP, 2011, Towards a Green Economy: Pathways to Sustainable Development and Poverty Eradication, www.unep.org/greeneconomy

33. Runnals, D. (2011) "Environment and economy: joined at the hip or just strange bedfellows?". S.A.P.I.EN.S. 4 (1)

34. "About UNFSS". UNFSS. Retrieved 2021-03-03.

35. "World Bank to lead economic push on nature protection". BBC News. Retrieved 11 May 2016.

36. "What is Green Economy? Here's a Simple Explanation". Sociology Group: Sociology and Other Social Sciences Blog. 2020-06-30. Retrieved 2021-06-02.

37. "Green Economy Roadmap" (PDF). International Chamber of Commerce. 2012. p. 10. Retrieved 31 January 2021.

38. UNDESA, (2012). A guidebook to the Green Economy. Archived 2013-01-27 at the Wayback Machine

39. "Advisory committee". 2015 Online International Conference on Green Engineering and Technologies (IC-GET). IEEE: 1-2. November 2015. doi:10.1109/get.2015.7453769. ISBN 9781467397810.

40. "2016 Global Green Economy Index" (PDF). Dual Citizen LLC. 19 September 2016. Retrieved 19 September 2016.

41. "Home - English - Siemens Global Website". Archived from the original on 26 November 2010. Retrieved 11 May 2016.

42. http://www.fcm.ca/Documents/reports/Ecological_Footprints_of_Canadian_Municipal ities_and_Regions_EN.pdf

43. (Reinhardt, 1999; King and Lenox, 2002; Wagner, 203; Wagner, et al., 2005)

44. Amory Lovins, Hunter Lovins, and Paul Hawken, authors of Natural Capitalism: Creating the Next Industrial Revolution, and Jay Conrad Levinson and Shel Horowitz, authors of Guerrilla Marketing Goes Green

45. "Nuclear Power in the USA - World Nuclear Association". www.world-nuclear.org. Retrieved 2021-01-29.

46. Kessler, Günter (2012), "The Development of Nuclear Energy in the World", Sustainable and Safe Nuclear Fission Energy, Power Systems, Berlin, Heidelberg: Springer Berlin Heidelberg, pp. 1-13, doi:10.1007/978-3-642-11990-3_1, ISBN 9783-642-11989-7, retrieved 2021-01-29

47. "Which Technology Will Most Impact The Future Of Energy? 18 Experts Share Their Insights". Disruptor Daily. 2019-06-29. Retrieved 2021-01-29.

48. "New Report: Who Will Control the Green Economy? - ETC Group". 8 January 2012. Archived from the original on 8 January 2012. Retrieved 7 April 2018.

49. "Green Economy - Green Economy Report". UNEP. 2011-11-16. Retrieved 2013-1109.

50. "The Green Economy: the Wolf in Sheep's clothing". Transnational Institute. Retrieved 11 May 2016.

51. U.Hoffmann (2011), "Some reflections on climate change, green growth illusions and development space" 
52. Spash, C.L. 2007. Fallacies of economic growth in addressing environmental losses: Human induced climatic change. Newsletter of the Australia New Zealand Society for Ecological Economics (ANZSEE), no. May, 2-4 Archived 2013-11-03 at the Wayback Machine

53. "EconPapers: Green Economy, Red Herring". Retrieved 11 May 2016.

54. Spash, Clive L. (2011-05-01). "Editorial: Terrible Economics, Ecosystems and Banking". Environmental $\quad$ Values. $20 \quad$ (2): 141-145. doi:10.3197/096327111X12997574391562.

55. Spash, C.L. 2008. How much is that ecosystem in the window? The one with the biodiverse trail. Environmental Values, vol. 17, no. 2, 259-284 Archived 2014-11-27 at the Wayback Machine

56. Jeremy Rifkin (2013), "The Third Industrial Revolution". VII,233-242

57. Scott Cato, Molly (2009). Green Economics: An Introduction to Theory, Policy and Practice. Earthscan. ISBN 978-1844075713. Retrieved 1 July 2014.

58. Green Growth Knowledge Platform

59. ICC Green Economy Roadmap - a guide for business, policymakers and society (2012) - ICC - International Chamber of Commerce (iccwbo.org)

60. A global movement for green \& fair economies | Green Economy Coalition

61. Green economy | UNEP - UN Environment Programme

62. Home - Green Economics Institute 


\title{
DETERMINING THE EFFECT AND EFFICIENCY OF INVESTING IN HUMAN CAPITAL
}

\author{
${ }^{1}$ Karim Seyidrza, ${ }^{2}$ Bakhtiyar Ismayilov, ${ }^{3}$ Zulfiya Mammadova \\ ${ }^{1}$ Associate Professor, Internationally qualified economist, ${ }^{2}$ Associate Professor, ${ }^{3}$ Associate Professor, \\ ${ }^{1,2,3}$ Azerbaijan State University of Oil and Industry, \\ E-mail: karimov.zizik2013@yandex.com
}

\begin{abstract}
In the concept "Azerbaijan 2021-2030: National Priorities for Socio-Economic Development" approved by the Decree of the President of Azerbaijan dated February 02. 2021 the following five National Priorities for socio-economic development of the country should be implemented in the next decade:

1. Steadily growing competitive economy;

2. A society based on dynamic, inclusive and social justice;

3. Competitive human capital and space for modern innovations;

4. Great return to the liberated territories;

5. Clean environment and "green growth" country.

It is clear that sustainable development is also a process of economic and social change in which harmonious development, balanced development, natural resources, investment, scientific and technological development, personal development and institutional change are linked and strengthen the current situation.
\end{abstract}

In our opinion, there are currently two concepts in the field of sustainable development: 1 . Models based on the concept of slow and moderate sustainable development (USA, England, France, Italy, Canada, and so on).

2. Models based on the concept of leaps and bounds (China, Japan, South Korea, Germany, Estonia, Malaysia, Singapore, and so on).

These models were formed in the early 50 and 60 of the twentieth century on the basis of the theory of human capital as an independent branch of economic analysis, thanks to the research of famous American economists, Nobel laureates T. Schultz and G. Becker. Thus, the term "human capital" was first used by T. Schultz, which meant a set of investments that increase a person's ability to work. The scientist argued that the well-being of the poor depended not on land, technology or their efforts, but on the knowledge and skills that constitute human capital. T. Schultz wrote: "All human resources and abilities are innate or acquired. Each human being is born with an individual gene complex that determines his or her innate human potential. We call human capital valuable qualities that a person acquires throughout his life and can be strengthened with appropriate investments. T. Schultz considered that the main result of investing in people is the accumulation of people's working capacity, their effective creative activity in society, the protection of their health. He proved that human beings have the necessary characteristics and properties that are productive because they are able to accumulate and reproduce capital [1,2].

G. Becker, the successor of T. Schultz, developed his idea by substantiating the efficiency of investments in human capital and forming an economic approach to human behavior. In the book "Human Capital", which is the basis for future research in this field, G. Becker defines human 
capital as a set of innate abilities, acquired skills, knowledge and motivations embodied in man, which he uses to produce. G. Becker calculated the economic efficiency of investing in education by comparing the benefits and costs of education. To calculate the additional income from higher education, the scientist deducted the lifetime earnings of people with secondary general education from the lifetime income of people with higher education. Education costs include both direct costs of acquisition and opportunity costs or lost profits - money lost by a person during the study period. The return on investment in education is calculated as the ratio of income from education to the cost of obtaining it.

Keywords: intellectual, innovation, human capital, model, scheme, cost, education, health.

Structure and characteristics of human capital in sustainable development: The following generalized model of sustainable development is applied in modern developed countries (Figure 1.).

As can be seen from the figure, the model consists of several systems. Along with other structural elements, innovation is important for sustainable development. Because innovation is an intellectual property, it is created on the basis of human capital and ensures the construction of industries on the basis of high innovative technologies.

There are many different approaches to the classification of human capital in the economic literature, which is explained by the complexity of the economic category. We propose to classify human capital according to the following criteria:

- components or components of human capital;

- forms of ownership operating in the country;

- levels of development of the country's economy;

- main directions of investments aimed at increasing human capital and sources of their formation;

- economic efficiency of investment in human capital development.

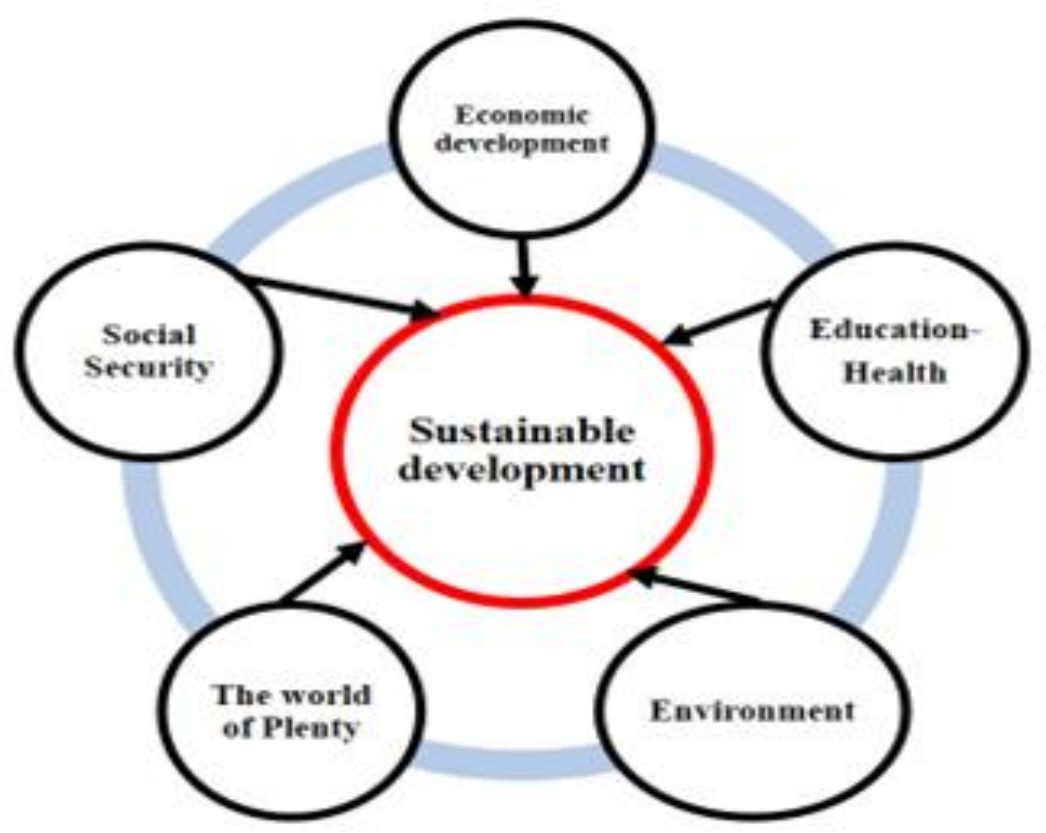

Figure 1. Generalized model of sustainable development 
Source: The model was developed by the authors.If we analyze the structure of human capital, we can distinguish two main components $[3,4,5]$ :

-educational capital;

-health capital.

The explanation of the distribution of human capital by type of property is as follows:

1. Educational capital is formed during the period of education and consists of the necessary knowledge and skills acquired by a person, which he uses to produce goods and services and is a source of income. Investments in educational capital are necessary to transform human instincts into natural qualities required in the labor market.

2. Health capital is an investment in a person needed to protect and improve a person's health, as well as to increase his activity. Health is the most important element of human capital, because its level directly depends on how well and fully a person can work and bring income to himself and his family, employer and the state.

3. National human capital or national capital includes labor resources, competitive industries, innovative technologies that ensure the country's competitiveness in the world market in the context of globalization.

4. Individual human capital is a fund of accumulated knowledge, skills and professional qualities that allow a person to earn extra income.

5. Corporate human capital (human capital of the enterprise) is expressed by the presence of highly qualified personnel, computer and information technology, know-how, which increases the efficiency of the enterprise.

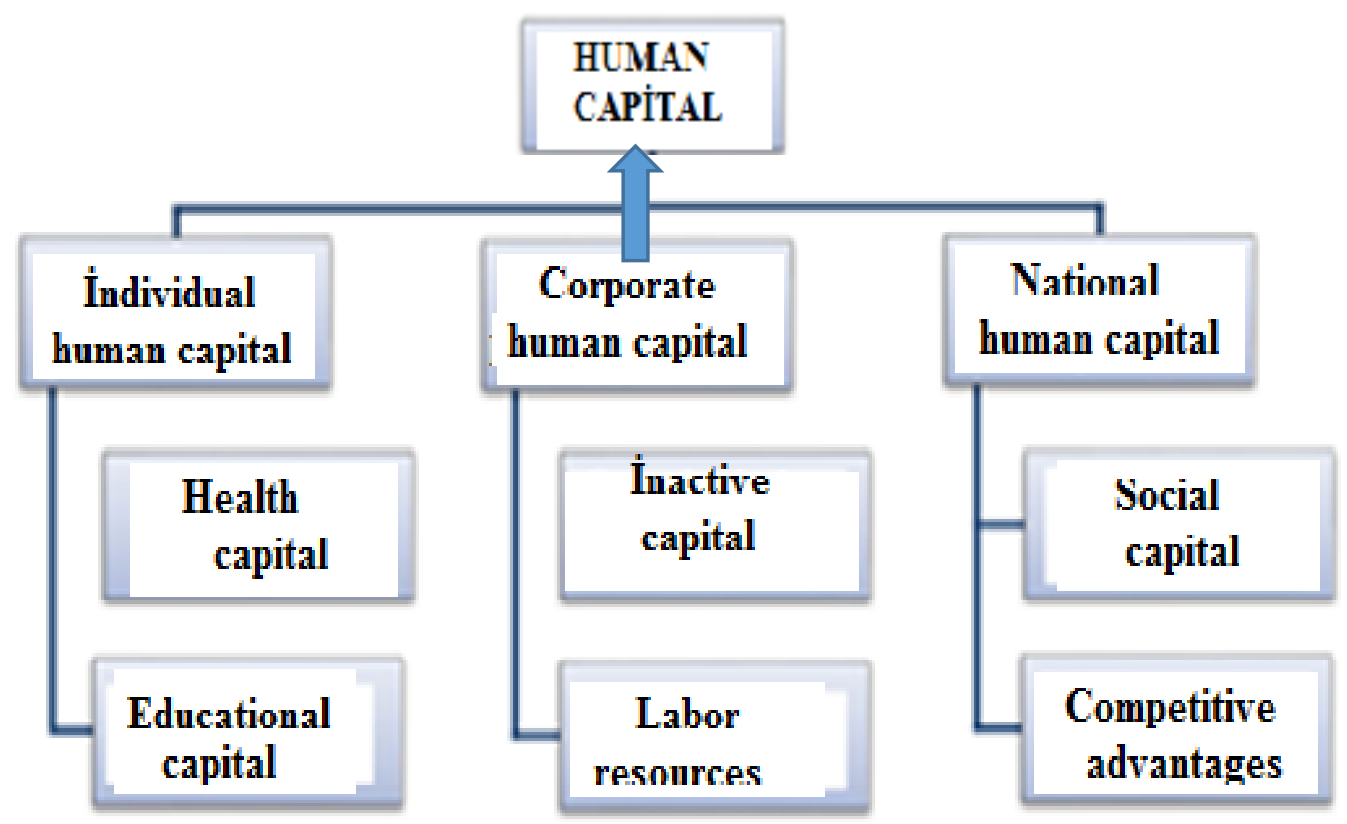

Figure 2. Scheme of distribution of human capital

Source: The scheme was created by the authors. 
It should be noted that until recently, the most active research was conducted on education capital, but now more attention is paid to health capital as a component and main part of human capital. Some scholars, in addition to educational and health capital, include biological or natural capital, family capital, and cultural capital in human capital $[9,11]$.

Human natural capital includes the mental and intellectual abilities of a person, as well as the biological inherited abilities that are passed on to him at birth, which include the health he received from his parents.

Family capital includes upbringing, motivation, and moral values passed down from generation to generation.

Assessment levels of human capital: Here we offer the following levels (Figure 3):

- macro level: characteristics of total human capital on the scale of the national economy;

- meso-level: assessment of human capital of large organizations and regions;

- micro level: characterization of human capital at the individual and enterprise level.

At each level, investments are required for the formation and accumulation of human capital, and depending on the direction of their investment, the types of costs are differentiated and the level of assessment is characterized by a set of relevant indicators.

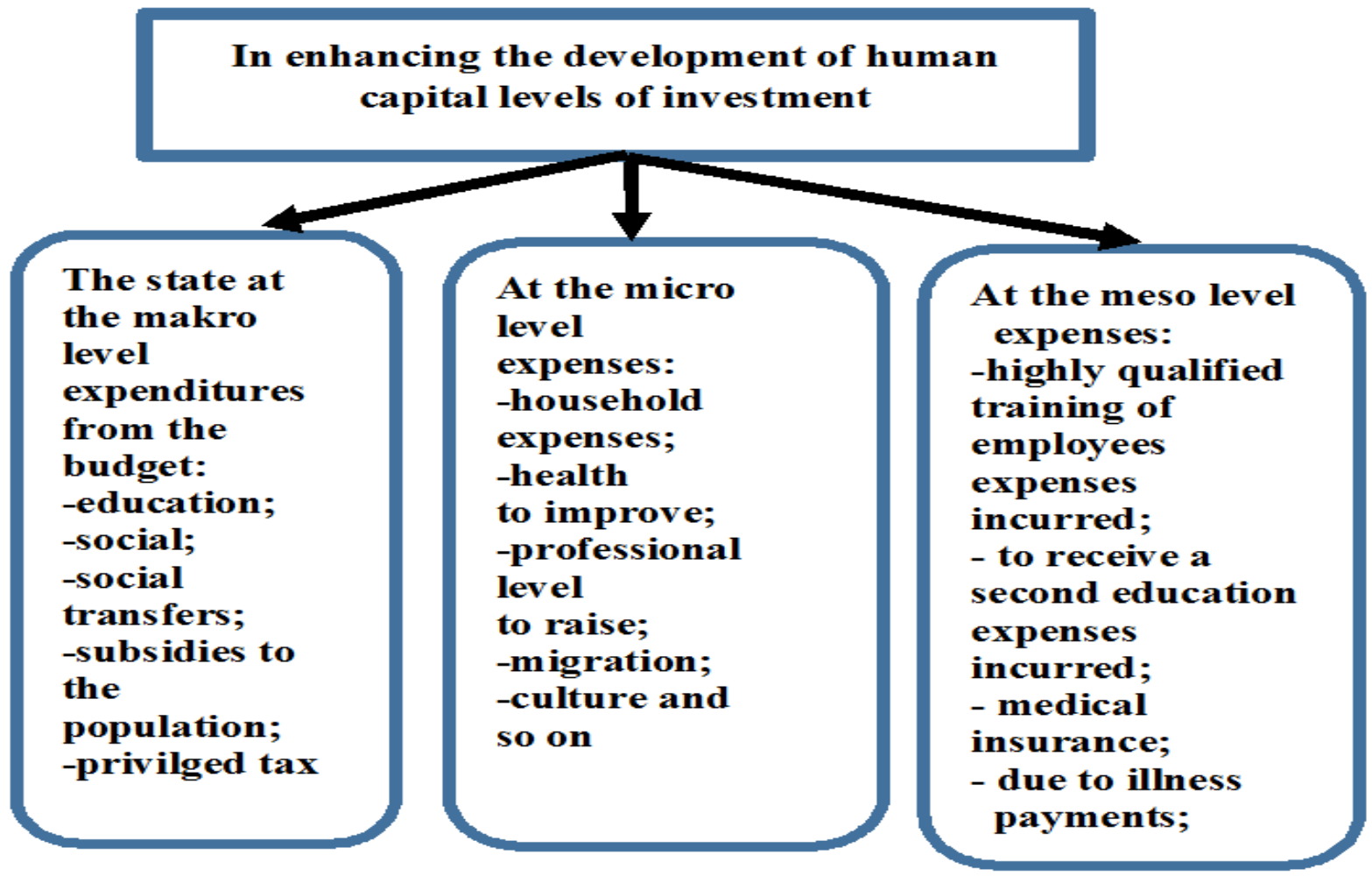

Figure 3. Levels of investment in human capital development

Source: The model was developed by the authors.

It is clear from the figure that the main cost elements include: 
- education costs: first of all, the costs of higher education, professional development, retraining and training;

- health protection and maintenance costs: the sum of costs that affect life expectancy, health level (health care, health insurance, disease prevention, housing improvement costs);

- Mobility costs associated with the migration of people looking for a better job.

As a result of our analysis, it is possible to say that the specific features of investments in human capital that distinguish them from other types of investments can be distinguished:

- Investment in human capital is long-term: the period of investment in education is about 15-20 years, and investment in health is carried out throughout life;

- Return on investment in human capital depends directly on the length of human life, especially the length of working age, and better and longer-term investments have a higher and longer-term effect in the future;

-human capital accumulates during human life, but is also subject to physical and moral erosion: physical erosion is determined by the aging of the human body, moral erosion is characterized by the obsolescence of knowledge and the reduction of the value of education.

Analysis of methods for assessing investment in human capital development

Methods used in the valuation of human capital in foreign countries: At present, the balance sheets of foreign firms do not reflect investments in human capital development, only intellectual capital in the form of intangible assets. As a result, the real market value of the enterprise is distorted and various methods are used to estimate the value of human capital and funds invested in it. The methods used for this purpose are [6,7,8]:

* Expert method or quality assessment method. This method assesses the quality characteristics of individual employees, as well as the workforce of the enterprise as a whole. Qualitative characteristics of the employee are represented by indicators such as level of education, work experience, specialty category, creativity, non-standard thinking.

* The method of estimating the value of human capital based on the determination of costs is one of the most common methods in practice. It is implemented in two ways:

-live ;

- indirectly.

The indirect method involves comparing the market value of an enterprise with the cost of replacing it. Nobel laureate in economics D. Tobin proposed a coefficient q calculated as the ratio of the market value of the assessed object to the value of its replacement. This includes the cost of setting up the business. If $\mathrm{q}<1$ and the value of the assessed object is lower than the cost of its replacement, then the investment in this object should not be made due to low human potential. If q> 1, then the object being valued has high human capital and the investment is attractive.

On the basis of the direct method, the total costs necessary for the formation of human capital in the enterprise are determined:

- cost of employees' salaries;

-improvement of working conditions and protection of life;

-training costs of employees;

- Improving the health of employees.

The formula proposed by us for calculating the nominal (potential) annual value of human capital in the enterprise is as follows: 


$$
\dot{\mathrm{I}}_{k}=S_{i n} x \frac{\left(V_{\theta h}+M_{m}+K_{m h x}+X_{t w}\right)}{H_{\text {ios }}},
$$

where $\dot{\mathrm{I}}_{k^{-}}$value of human capital in the enterprise, man; $S_{\text {in }}$ - total number of staff, people; $\mathrm{V}_{\text {oh }}$ actual annual salary of general employees, man .; $\mathrm{M}_{\mathrm{m}}$ annual financial incentive fund for employees of the enterprise, man .; $\mathrm{K}_{\mathrm{mhx}}$ - annual expenses related to rewarding and motivating employees of the enterprise from additional financial sources, man .; $\mathrm{X}_{\mathrm{tu}}$ - costs associated with the education and training of employees, man .; Hios - the average annual number of employees in the enterprise, people.

* Eric Flamholz's model of determining the initial and replacement costs of personnel. This model takes into account the company's costs of acquisition and replacement, rather than staffing.

* The method of finding the individual value of the employee. This method uses conventional value concepts developed by scientists at the University of Michigan. The individual value of an employee is determined taking into account the probability that he will work in the organization for a certain period of time. The expected selling price is represented by two elements:

-expected conditional value;

- continuation of the employee's work in the organization.

* The method of capitalization of future income is the most common method, where the value of human capital is determined based on its use, ie the economic effect of gross income. In other words, measuring the value of human capital involves determining the value of future income flows for the present and present.

Of course, the methods discussed above do not provide a complete list of all available methods for assessing the effectiveness of human capital investments. However, it can be understood that the difficulty in determining the value of human capital and the effectiveness of investments in it is often due to the lack of statistical data required for analysis $[7,12]$.

Impact of human capital on the economic growth of the enterprise: Today, the innovative development of the enterprise cannot be ensured due to previous experience in the field of human resource management based on traditional methods of personnel management. It is inevitable that a significant part of the innovation activity of enterprises will move in the direction of accumulation of human capital, adequate to the innovation-type tasks of the economy.

The accumulation of human capital is conditioned by the constant increase in knowledge, skills, production experience and skills of employees throughout their lives. Higher vocational education plays a special role in this process, which will form the professional, special and innovative skills of employees. Achieving a competitive advantage of the enterprise is mainly due to knowledge and innovation. Increasing labor productivity in an enterprise is not possible without investing in fixed capital and especially human capital, because the level of the latter determines the success rate of innovation, as well as the efficiency of the use of fixed capital [11,13].

The main effect of investing in human capital is the highly productive work of each employee, which confirms the positive correlation between the level of development of human capital and the employee's salary. It follows that the greater the amount of human capital, the higher the rate of labor productivity and economic growth (Figure 4).

The experience of developed countries shows that the main condition for economic growth is the accumulation and maintenance of human capital, as well as its development and growth. 
Following a survey of 192 countries, World Bank experts concluded that $16 \%$ of economic growth in countries is due to investment in fixed capital or physical capital, $20 \%$ - to natural capital, and $64 \%$ - to the level of development and quality of human capital.

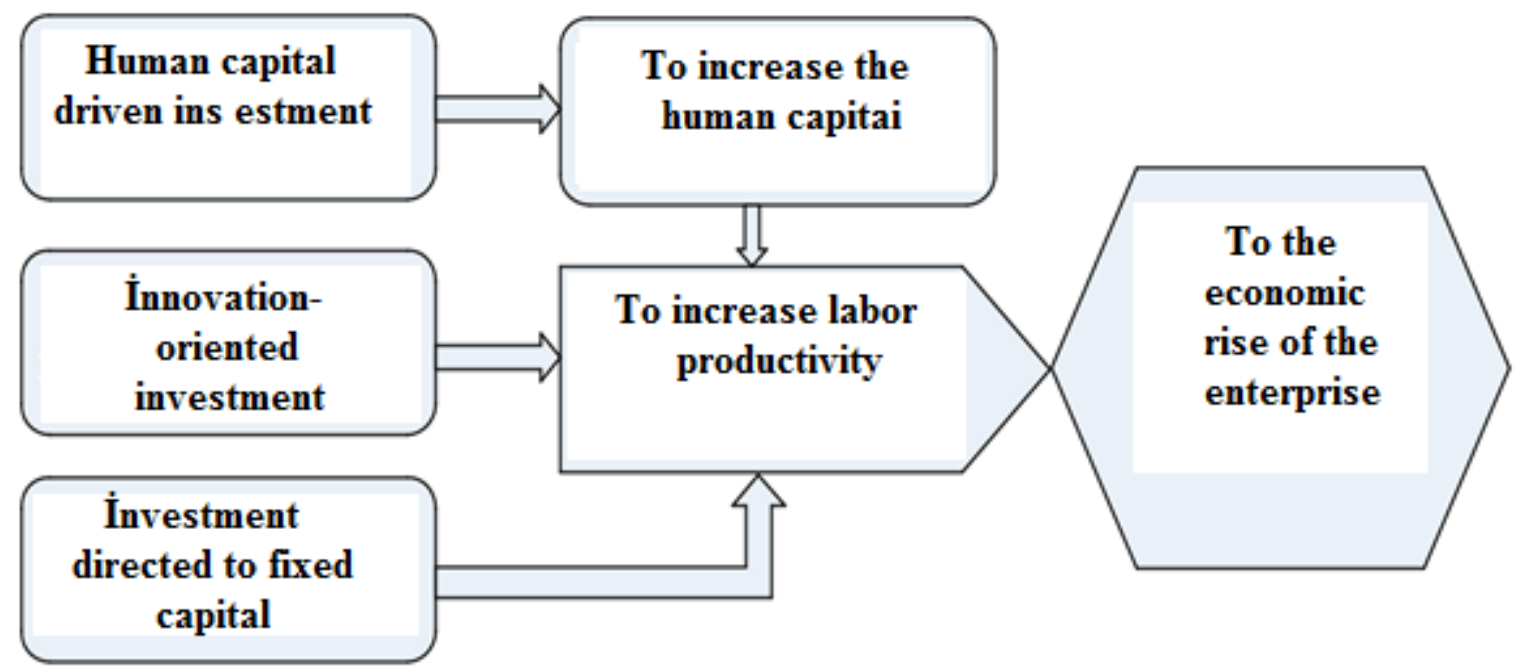

Figure 4. The impact of investment costs on the economic growth of the enterprise

\section{Source: The model was developed by the authors.}

In countries such as Germany, Switzerland and Japan, the share of human capital reaches $80 \%$. In Germany and France, the share of funds allocated for social protection is almost half of the state budget $-43.3 \%$ and $43.1 \%$, respectively. Economic development in these countries is measured by comparing GDP per capita in comparative estimates for the period under study.

The share of expenditures on the development of science from the budget of Azerbaijan in the state budget in 2018 is only 0.01\% (117.8: 22731.6), which is higher than in Estonia, Israel, South Korea, Germany, Japan, Singapore and other developed countries. at a very low level (Table 1).

Table 1. Dynamics of expenditures allocated from the state budget for the development of human capital in Azerbaijan

\begin{tabular}{|c|c|c|c|c|c|c|c|}
\hline Years & $\begin{array}{c}\text { State } \\
\text { budget } \\
\text { (million } \\
\text { manat) }\end{array}$ & $\begin{array}{c}\text { Educational } \\
\text { expenses } \\
\text { (million } \\
\text { manat) }\end{array}$ & $\begin{array}{l}\text { Health } \\
\text { care costs } \\
\text { (million } \\
\text { manat) }\end{array}$ & $\begin{array}{l}\text { Science } \\
\text { costs } \\
\text { (million } \\
\text { manat) }\end{array}$ & $\begin{array}{l}\text { Spending on } \\
\text { Culture, Media } \\
\text { and sports } \\
\text { (million manat) }\end{array}$ & $\begin{array}{l}\text { Total } \\
\text { costs } \\
\text { (million } \\
\text { manat) }\end{array}$ & $\begin{array}{c}\text { Share in the } \\
\text { state budget } \\
\text { (\%-lə) }\end{array}$ \\
\hline 2009 & 10503.9 & 1147.9 & 402.4 & 83.3 & 158.3 & 1791.8 & $17 \%$ \\
\hline 2010 & 11765.9 & 1180.8 & 429.2 & 92.8 & 168.4 & 1871.2 & $16 \%$ \\
\hline
\end{tabular}


VOLUME 17 ISSUE 072021

JOURNAL OF SOCIAL RESEARCH \& BEHAVIORAL SCIENCES

\begin{tabular}{|c|c|c|c|c|c|c|c|}
\hline 2011 & 15397.5 & 1268.5 & 493.4 & 106.1 & 189.9 & 2057.9 & $13 \%$ \\
\hline 2012 & 17416.5 & 1453.2 & 609.4 & 116.7 & 240.8 & 2420.1 & $14 \%$ \\
\hline 2013 & 19143.5 & 1437.7 & 618.9 & 117.0 & 274.9 & 2448.5 & $13 \%$ \\
\hline 2014 & 18709.0 & 1553.9 & 665.3 & 124.2 & 294.0 & 2637.4 & $14 \%$ \\
\hline 2015 & 17784.5 & 1605.1 & 708.2 & 113.2 & 272.4 & 2698.9 & $15 \%$ \\
\hline 2016 & 17751.3 & 1754.4 & 702.5 & 110.2 & 687.4 & 3254.5 & $18 \%$ \\
\hline 2017 & 17594.5 & 1742.7 & 704.7 & 109.8 & 253.3 & 2810.5 & $16 \%$ \\
\hline 2018 & 22731.6 & 1966.6 & 709.9 & 117.8 & 299.5 & 3093.8 & $14 \%$ \\
\hline
\end{tabular}

\section{Source: Compiled by the authors on the basis of the State Statistics Committee of the} Republic of Azerbaijan.

Unlike our country, developed countries, in addition to achieving a high level of economic development and quality of life of the population in the distribution of budget funds, prefer to invest in human resources rather than fixed capital. From this point of view, the most obvious manifestations of the crisis in the impact of the components of human capital on the economic growth of the country are as follows:

- devaluation of human capital in the economically active population;

-creation of intellectual unemployment;

- higher education workers are forced to change their profession and seek additional income;

- "brain drain" (migration of scientific personnel from Azerbaijan abroad);

- lack of experienced and modern teaching staff capable of training qualified personnel.

The result: 1. As a result of the study of human capital, its structure, formation factors, distinctive features and properties, it can be said that human capital is a complex economic category, its logical study and analysis is an important factor from a scientific point of view.

2. There are many interrelated problems in the classification of human capital, as a result of which the study of human capital becomes much more complicated. Therefore, in the future it is necessary to develop a unified system of classification of human capital, which will eliminate the difficulties in its assessment.

3. Due to the increase in the level of education of the population in the country, the work of each person will be more productive if the creation of innovative technologies and the continuation of their application in the economic sphere will create conditions for sustainable economic development.

4. Simultaneous solution of three main problems: innovative development, technological modernization of industry and development of human capital is an important condition for the success of the innovative leap in our country. 


\section{REFERENCES}

1. Stepanov Ye.B. Ontologic and gnoseological preconditions methodology of the human capital // Economics and management. 2010. № 2. p. 98-101

2. Parshina NV Human capital: essence, content, specificity. The world of modern science. 2013. № 3. c. 2-7.

3. Simon Kuznets [Electronic resource] // The library of economics and liberty. 2016. URL: http://www.econlib.org/library/Enc/bios/Kuznets.html.

4. Mazur VV Problems of assessment of the capital of the organization [Electronic resource] // Internet-magazine. 2011. URL: http://mami.ru/science/aai77 /scientific/article/s11/s11_14.pdf.

5. Rudenko D. Yu., Tilimbaeva A.B. Investment in human capital and socio-economic development: relationship analysis and impact evaluation // Tyumen state university herald. 2013. № 11. p. 19-24

6. Savchenko VV Types of investments in human capital and their efficiency // Questions of structuring the economy. 2010. № 2. c 417-418.

7. Buldashev ES Influence of investment size on investment results in human capital // Theory and practice of public development. 2013. № 4. c. 238-239.

8. Sakalas A. Evaluation of Human Capital Role in the Value Creation Process // Procedia Social and Behavioral Sciences. 2014. № 156. p. 80-81.

9. Tuguskina GN Methodology of assessment of human capital of enterprises [Electronic resource] // Personnel management. 2009. URL: http://www.top-personal.ru/issue.html.

10. Anikina E., Ivankina L., Tumanova I. Human Well-being and Educational Investment Efficiency // Procedia - Social and Behavioral Sciences. 2015. № 166. p. 49-51.

11. Personnel training and development [Electronic resource] 2016. URL: http://www.rosneft.ru/Development/personnel/staff_development/.

12. Arslanov Sh.D. To the question of assessment of efficiency of investments in the human capital // Questions of structuring of economy. 2012. № 3. C. 77-78.

13. Pestov IP Review of approaches to the assessment of the effectiveness of investments in human capital enterprises // Questions of structuring the economy. 2010. № 2. C. 388389.

14. Maysak OS SWOT analysis: object, factors, problem strategiessearch for links between factors // Caspian Journal: Management and High Technologies. 2013. № 1. C. 153-1575

15. Romanova EB Investments in the development of human capital // Izvestia of the Russian State Pedagogical University. A.I. Herzena. 2010. № 1. C. 437-438. 


\title{
PROGNOSTIC MEANING OF SERUM NSE AS THE FACTOR OF BAD OUTCOME IN SECONDARY BRAIN DAMAGE
}

\author{
${ }^{1}$ Ainur Tokshilykova, ${ }^{2}$ Zhanslu Sarkulova, ${ }^{3}$ Zhusupbek Satenov, ${ }^{4}$ Marat Sarkulov, \\ ${ }^{5}$ Arzyhiya Tleuova, ${ }^{6}$ Botagoz Kalieva, ${ }^{7}$ Kamila Daniyarova, ${ }^{8}$ Adina Darbaeva, ${ }^{9}$ Gulnara \\ Kiliptari \\ ${ }^{1}$ Assistant at the Department of Anesthesiology and Reanimatology, \\ ${ }^{2}$ Doctor of Medical Sciences, Professor, \\ ${ }^{3}$ Assistant at the Department of Anesthesiology and Reanimatology, \\ ${ }^{4}$ Candidate of Medical Sciences, the chairman of Urology Department, \\ ${ }^{5}$ Assistant at the Department of Anesthesiology and Reanimatology, \\ ${ }^{6}$ Assistant at the Department of Anesthesiology and Reanimatology, \\ ${ }^{7}$ Assistant at the Department of Anesthesiology and Reanimatology, \\ ${ }^{8}$ Resident at the Department of Anesthesiology and Reanimatology. \\ ${ }^{9} \mathrm{Head}$ of ICU department. Associate professor \\ Tbilisi State Medical University. Head of ICU department. Associate professor \\ 1,2,3,4,5,6,7,8 Department of Anesthesiology and Reanimatology, West Kazakhstan Marat Ospanov Medical University. \\ ${ }^{9}$ Tbilisi State Medical University. \\ Email: Ainur.t_83@mail.ru
}

This research is dedicated to the study of brain neuronspecific markers and indicators of brain damage outcome.

Purpose of the study: To examine the prognostic role of serum NSE as the predictor of unfavorable outcome in traumatic and vascular brain damages.

Methods: Prospective cohort study with 219 patients. Blood serum neuronspecific markers (NSE,S100B), acid-base state, blood gas were derived during the period of observation: upon enrolment, on the 3-rd, 5-th and 7-th days spent in the hospital in the intensive care unit.

Results: The most significant risk factor of unfavorable outcome is the marker NSE with the cut point $12,5 \mathrm{ng} / \mathrm{ml}$. The results of the analysis indicate the presence of a statistically significant direct relationship between NSE> $12.5 \mathrm{ng} / \mathrm{ml}$ and $\mathrm{LDH}$, compared to other variables, 3.7 times more often; with an increase in blood lactate more than $4,1 \mathrm{mmol} / 1$ almost 3,8 times; with GCS 13 points below by 1,7 times; $\mathrm{S} 100 \geq 0,2$ by 2,8 times; with an increase of $\mathrm{PCO} 2<38,5$ it was documented more than 3 times often. The measure of certainty the resulting model by the pseudo R2 Nagelkerke criterion-250.6; logLikelihood - 154.04 which corresponds to the excellent predictive ability of the mathematical model. The best predictive value of the model is a cut-off point of 88.89\%, AuROC-0.809; Se-51.59\%; Sp-95.06\%; NPV-55.80\%; PPV-94.20\%.

This model can be used to predict the outcome in patients with acute cerebral pathology.

Keywords: strokes, brain traumatic damages, neuronspecific markers, diagnostic and prognostic criterias, stroke outcomes.

Traumatic and vascular lesions of the brain cause abnormal brain functioning due to disturbances in the vascular system. Millions of people are admitted to emergency departments every year for brain damage, of which 1.5 million die $[1,2]$. Many deaths occur before the patient arrives at the hospital or during treatment [3]. However, ongoing inflammatory processes in secondary brain damage cause damage to molecular cells, changes in metabolism and cerebral blood flow, axonal disruption and apoptosis, which can influence the development of long-term mortality in the separated period of cerebral damage $[4,5]$. According to the authors, these patients have a reduced 
points with GCS in assessing the severity, dynamics and prediction of outcomes of neurological status [6,7] . Also, in computed tomography of the brain, the diagnostic value is low, due to low sensitivity and insufficient specificity [8,9]. Magnetic resonance imaging allows us to assess the severity of neuroaxonal injuries, but its inaccessibility to some hospitals, long study time, often severe patients requiring continued mechanical ventilation significantly limit its use [8, 10]. In daily clinical practice, due to invasiveness and the presence of certain indications, the control of intracranial pressure is also limited [10]. Therefore, more and more clinical and experimental studies are aimed at studying the role of neurospecific blood proteins in the diagnosis and prognosis of outcomes of acute cerebral neuropathology [7,11]. In diseases associated with the direct involvement of nervous tissue in the pathological process, qualitative and quantitative determinations of the NSE protein in cerebrospinal fluid or blood serum provide valuable information on the severity of neuronal damage and violations of the overall integrity of the blood-brain barrier [12].

NSE also characterizes the degree of post-ischemic brain damage. NSE has a long half-life compared to S100B. Unlike S100B, which is present in high concentrations in glial cells and Schwann cells, NSE originates predominantly from neurons and neuroendocrine cells [13, 14]. It is possible that S100B simply reflects the inflammatory response of glial cells, while NSE may serve as a marker of neuronal damage $[15,16]$.

The assessment of the significance of markers in the prediction of the dominance of injuries was carried out by us using the Wald method. The ability of NSE as a predictor of mortality has been shown in several studies [17]. However, a number of studies refute these results [18]. Different results may be associated with methodological differences, sample size, out-of-the-box tests, and different demographics. To further deepen the usefulness of NSE as a predictor of poor outcome, this article will present its predictive value in vascular and traumatic brain injury.

Methods: The study was carried out in accordance with the standards of good clinical practice (Good Clinical Practice), the principles of the Declaration of Helsinki and in accordance with the principles of the ethical commission of the West Kazakhstan Medical University named after Marat Ospanov No. 12 dated January 30, 2018 [11] The content of NSE protein in blood serum upon admission and in dynamics was determined in 219 patients with vascular and traumatic brain diseases who were treated in the intensive care units and intensive care units of stroke centers in Aktobe (Republic of Kazakhstan) for the period from 2018 to 2020. The study included patients with hemorrhagic strokes (HI) - 146 patients $(66.6 \%)$, ischemic stroke $43(19.6 \%)$ and with acute closed craniocerebral injuries of mild and moderate severity - 30 (13.60\%). Criteria for inclusion in the study of patients with hemorrhagic stroke were cases of intracerebral hemorrhage with a hematoma volume of more than $30 \mathrm{~cm} 3$ (mainly hemispheric hemorrhages); patients with ischemic stroke - with the presence of cerebral infarction, confirmed by clinical and CT data; patients with severe craniocerebral trauma - moderate and severe cerebral contusions. Patients with: intracerebral hemorrhages with a hematoma volume of more than $80 \mathrm{~cm} 3$, with severe decompensated somatic diseases, with benign and malignant tumors of the brain, lungs and skin were excluded from the main group. According to the outcome of the disease, regardless of the diagnosis, the patients were divided into groups: survivors $-59.3 \%(\mathrm{n}=130)$ and deaths $-40.6 \%$ $(n=89)$. Laboratory studies of the NSE were carried out upon admission and in dynamics. The supernatant was removed and stored at $-80^{\circ} \mathrm{C}$ until analysis. For NSE determination, all samples were analyzed in duplicate using immunoluminometric assay using a human ELISA kit. To 
measure blood gases, lactate and glucose, samples were analyzed using an ABL 735 analyzer (Radiometer; Denmark). The neurological grading scales GCS (Glasgow Coma Scale) were used to assess the severity of brain damage and to predict the outcome of the clinical course of the disease in patients. The study was approved by the hospital ethics committee and informed consent.

The distribution of patients in groups by sex $\left(\chi^{2}=0.0184, \mathrm{p}=0.8922\right)$ and age $\left(\chi^{2}=0.0183, \mathrm{p}=\right.$ 0.4288), where all predictors were examined were comparable. To determine the possibility of using the NSE protein in predicting the outcome of secondary brain injuries in vascular and traumatic brain injury, an analysis of variance was carried out. Maximum, minimum, and mean protein levels were assessed for each outcome group.

Statistics: The study of the statistical relationship between a qualitative trait and clinical outcome was carried out using the analysis of contingency tables, with the calculation of the Pearson $\chi^{2}$ criterion. If the condition of applicability of the $\chi 2$ criterion is not met (more than $25 \%$ of cells in the contingency table have an expected frequency of less than 5), the analysis was carried out in pairs according to the two-sided Fisher's exact test $(2 \mathrm{p}(\mathrm{F}))$. In the case of insufficient statistical significance of the relationship between two nominal features in a multi-field contingency table, several similar gradations of a feature were combined into one, followed by calculation of the Pearson $\chi^{2}$ criterion with the achieved level of statistical significance (p) and the odds ratio (OR) with a $95 \%$ confidence interval $(95 \% \mathrm{CI})$. The study of the relationship between the quantitative and qualitative trait was carried out using one-way logistic regression analysis with the calculation of Wald's $\chi 2$ statistics with the achieved level of statistical significance and OR with 95\% CI. Multiple linear regression analysis was performed to identify variables independently associated with serum NSE levels. NSE was used as a dependent variable. A step-by-step forward technique was used. Data are presented as mean $\pm \mathrm{SD}$ or median and percentile, p-values less than 0.05 were considered significant.

The construction of mathematical models for predicting the risk of an unfavorable outcome was carried out using the method of multivariate binary logistic regression analysis with step-by-step inclusion of independent variables. The effect of the independent variable on the probability of outcome was determined using OR and 95\% CI. To assess the quality of the mathematical model, we calculated the Nigelkirk coefficient of determination (R2), which shows the share of the influence of all variables included in the model on the variance of the dependent variable, as well as the Hosmer-Lemeshov goodness test, which makes it possible to establish how the model agrees with the initial data. The discriminatory ability of the mathematical model was assessed based on the analysis of the classification table. Evaluation of the predictive efficiency of the model was carried out using the analysis of ROC curves, with the calculation of the area under the ROC curve, called AUC (Area Under Curve). In the statistical analysis procedures, the achieved level of statistical significance (p) and the number of degrees of freedom (df) were calculated. The critical value of the level of statistical significance in the study was $p<0.05$.

The results of the study were subjected to statistical analysis and mathematical data processing using the Statistics (SPSS25) software package.

Results: Neurospecific enolase (NSE) performs an enzymatic function by participating in glycolysis processes and is one of the specific markers of nerve tissue damage. A very rapid increase in blood concentration was noted during hypoxia, brain injury and other pathological 
conditions accompanied by massive destruction of neurons. When comparing the groups of survivors and deceased, it was found that the concentration of the NSE protein on the first day after injury increased by 2 and 3 times, respectively. In the surviving patients, on the third day after the incident, the NSE level returned to the control figures, and in the deceased - it remains high relative to the control indicators. Figure 1 shows the distribution of the mean NSE protein for each outcome group.

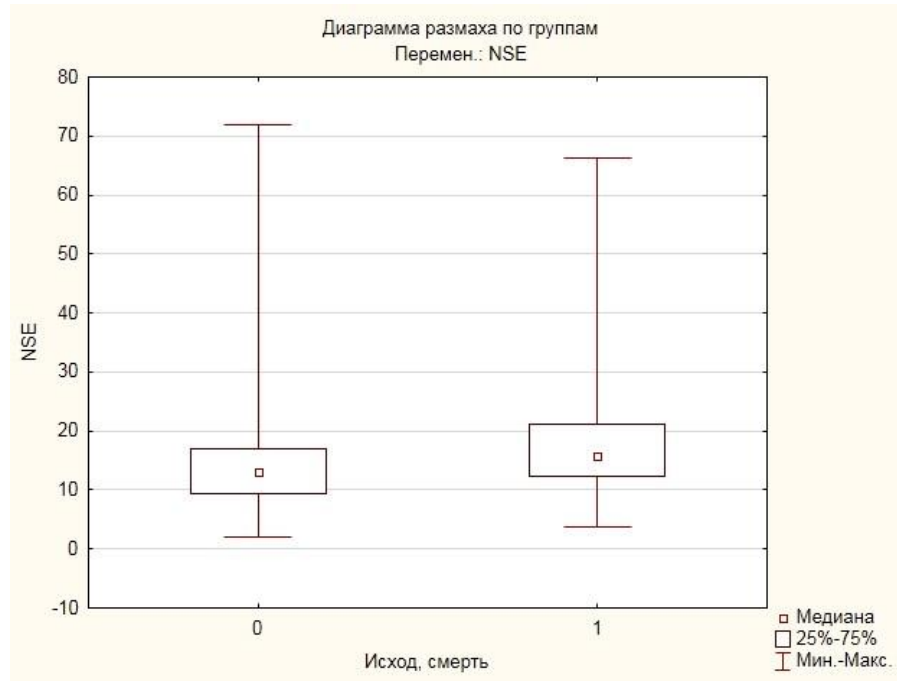

Figure 1. Diagram of NSE range in disease outcome groups.

As shown by the studies, when comparing the dynamics of the content of neuron-specific proteins in the groups of surviving and deceased patients, statistically significant differences were determined. So, if in both groups of patients there was a 1.4-fold increase in NSE on day 114.76 95\% CI (12.98; 16.54) versus $20.7595 \%$ CI (16.10-25.39) $\mathrm{ng} / \mathrm{ml}$, respectively for the groups), then a significant increase in its concentration was observed in the group of patients who died on the 3rd day by 1.39 times $19.7595 \%$ CI $(14.52-24.97) \mathrm{p}=0.0260)$ by the background of the treatment, which suggested an early occurrence of an unfavorable course of the disease.

In all other fatalities, the NSE concentration increased over time, reaching a maximum at the time of death. Analysis of variance was performed to determine the statistically significant difference. Maximum, minimum, and mean NSE protein levels were assessed for each outcome group.

The revealed differences in the nature of the body's response to brain damage gave us the basis for the subsequent development of a differential diagnostic algorithm. Variables showing a statistically significant relationship with (predictors of) an increase in target NSE $>12.5 \mathrm{ng} / \mathrm{ml}$ by factors of secondary brain injury in univariate analysis were introduced into multiple LRA step by step. In the first step, clinical and laboratory parameters were included (simple model) The results of the analysis are presented in Table 1.

Table 1. Predicting the risk of increasing NSE> $12.5 \mathrm{ng} / \mathrm{ml}$.

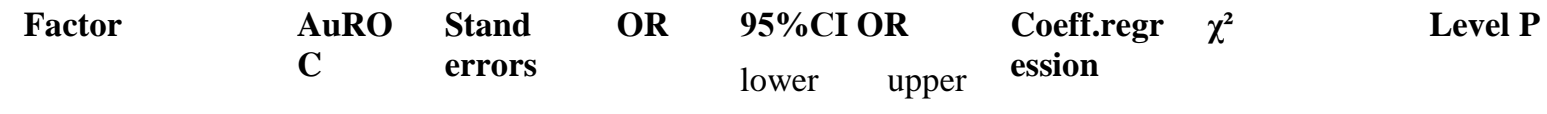


VOLUME 17 ISSUE 072021

JOURNAL OF SOCIAL RESEARCH \& BEHAVIORAL SCIENCES

\begin{tabular}{|c|c|c|c|c|c|c|c|c|}
\hline Const & & $-1,9577$ & & & & $-1,9576$ & 19,4029 & $<0,0001$ \\
\hline $\mathrm{LDH}^{1} \geq 218$ & 0,728 & 0,3376 & 3,74 & 1,93 & 7,25 & 1,3195 & 15,279 & $<0,0001$ \\
\hline $\mathrm{GCS}^{2}<13$ & 0,766 & 0,3447 & 1,68 & 0,85 & 3,29 & 0,5168 & 2,2485 & 0,1337 \\
\hline Age $<53$ & 0,783 & 0,3901 & 2,95 & 1,37 & 6,34 & 1,0829 & 7,7076 & 0,0055 \\
\hline$S 100 B \geq 0,2$ & 0,790 & 0,3868 & 2,79 & 1,31 & 5,95 & 1,0256 & 7,0288 & 0,0080 \\
\hline $\mathrm{PCO} 2^{3} \geq 38,5$ & 0,804 & 0,3741 & 3,08 & 1,48 & 6,41 & 1,1242 & 9,0311 & 0,0027 \\
\hline Lactate & 0,809 & 0,6625 & 3,29 & 0,90 & 12,07 & 1,1922 & 3,2392 & 0,0719 \\
\hline \multicolumn{9}{|c|}{$\begin{array}{l}\text { Notes: } \\
1 \text { LDH- lactate dehydrogenase } \\
2 \text { GCS- The Glasgow Com Scale } \\
3 \text { S100B - calcium binding protein } \\
4 \text { PCO2- partial pressure of carbon }\end{array}$} \\
\hline
\end{tabular}

The measure of certainty of the resulting model according to the pseudo R2 criterion is $250.6 \%$. Independent factors associated with NSE were: $\mathrm{LDH} \geq 218$, GCS $<13$, Age $<53, \mathrm{~S} 100 \mathrm{~B} \geq 0.2, \mathrm{PCO} 2 \geq 38.5$, Lactate $\geq 4$. The results of the analysis indicate the presence of a statistically significant direct relationship between NSE>12.5 ng / $\mathrm{ml}$ and LDH, compared to other variables, 3.7 times more often; with an increase in blood lactate above 4.1 mmol /l, almost 3.8 times; with a Glasgow scale below 13 points by 1.7 times; S100B 0.2 by 2.8 times; with an increase in PCO2 <38.5 were documented more than 3 times more often. The measure of certainty of the resulting model by the criterion of pseudo R2 Nagelkerke-250.6; logLikelihood 154.04.

The logistic regression equation of the model is as follows:

\section{Risk $=1 /(1+\operatorname{Exp}(-(-1,958+1,319 * \mathrm{LDH} \geq 218+0,517 * \mathrm{GCS}<13+1,083 *$ Age $<53+1,026 * \mathrm{~S}$ $100 \mathrm{~B} \geq 0+1,124 *$ PCO2 $\geq 38+1,192 *$ Lactate $\geq 4)))$}

Where $\mathrm{P}$ is the probability of risk of increasing NSE $>12.5 \mathrm{ng} / \mathrm{m}$, e-base of natural logarithm $(\mathrm{e}=$ 2.72), -1.9577 is a constant;

The best predictive value of the model had a cut-off point of $88.89 \%$, AuROC-0.809; Se-51.59\%; Sp-95.06\%; NPV-55.80\%; PPV-94.20\%.

When forming multivariate analysis of variance, when predicting the risk NSE> $12.5 \mathrm{ng} / \mathrm{ml}$, we obtained regressions from several factors, which are indicated in Table 11.

Table 11. Regressions

\begin{tabular}{|l|l|l|l|l|l|l|l|}
\hline Factor & $\begin{array}{l}\text { Cut } \\
\text { off }\end{array}$ & $\begin{array}{l}\text { Relative risk } \\
(\mathbf{9 5 \%} \text { CI) }\end{array}$ & Se & Sp & $\boldsymbol{\chi}^{\mathbf{2}}$ & AuROC & $\begin{array}{l}\text { P-level } \\
\text { (df=1 })\end{array}$ \\
\hline 4 factor $\geq 1,0$ & 1,0 & $4,54(2,01 ; 10,24)$ & $96,24 \%$ & $32,56 \%$ & 33,8465 & 0,80 & $<0,0001$ \\
\hline 3 factor $\geq 1,0$ & 1,0 & $3,66(1,86 ; 7,18)$ & $94,74 \%$ & $34,88 \%$ & 32,6368 & 0,79 & $<0,0001$ \\
\hline 5 factor $\geq 2,0$ & 2,0 & $2,45(1,56 ; 3,86)$ & $89,47 \%$ & $40,70 \%$ & 27,3740 & 0,82 & $<0,0001$ \\
\hline
\end{tabular}

Regression consisting of 4 factors relative risk of poor outcome 4.54 (95\% CI 2.01; 10.24); Se96.24\%, Sp-32.56\%, $\chi^{2}-33.8465$, AuROC-0.80.

We calculate: if LDH> 218 then score $=35$; GCS $<13$ then score $=15$; Age $<53$ then score $=24$; $\mathrm{S} 100 \geq 0.2$ then score $=26$. Total $=100 \mathrm{bb}$. If on admission the patient gains $100 \mathrm{bb}$ in the patient during the study, the risk of NSE is> $12.5 \mathrm{ng} / \mathrm{ml}$ and the mortality rate exceeds 4.54 times. To 
predict the NSE score, we used multiple regression analysis with the NSE dependent variable and the independent variables LDH, Lactate, S100, Glucose. All variables listed in the table predicted the quantitative value of this marker. Below are the extended results of the regression analysis in Table 2.

Table 2. Advanced regression results

factor

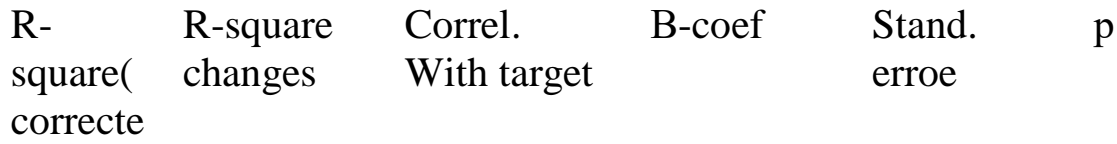

constant

d)

$\begin{array}{lllllll}\mathrm{LDH}^{1} & 18,2 \% & 41,87 \% & 0,43 & 0,008 & 0,0085 & <0,0001 \\ \text { lactate } & 22,4 \% & 23,62 \% & 0,28 & 17,748 & 0,6259 & 0,0105 \\ \text { S100B } & 41,4 \% & 19,43 \% & 0,55 & 52,207 & 0,5757 & <0,0001 \\ \text { glucose } & 42,1 \% & 0,50 \% & 0,05 & -3,529 & 0,3241 & 0,0598\end{array}$

Notes:

1.LDH-lactatdehydrogenaze

2. S100- calcium binding protein

Model quality

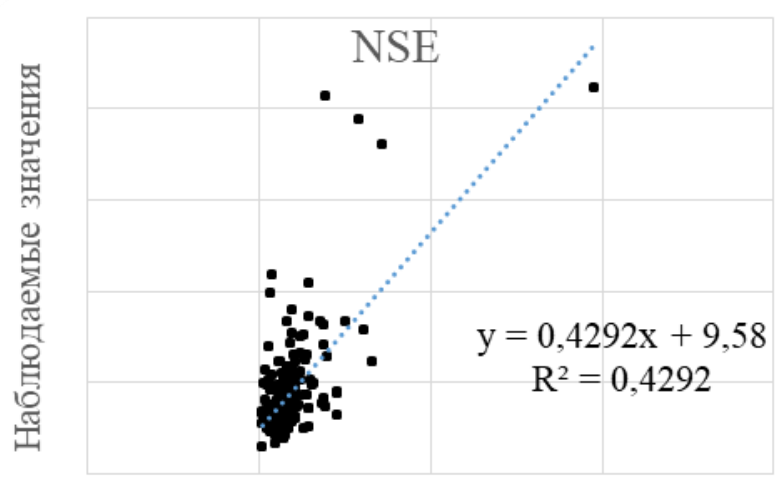

\begin{tabular}{|l|l|}
\hline R-square & $42,9 \%$ \\
\hline R-square corrected. & $42,1 \%$ \\
\hline Standard error Y & 12,46 \\
\hline F-statistic of degrees of & 40,22 \\
\hline $\begin{array}{l}\text { number of } \\
\text { freedom }\end{array}$ & 214 \\
\hline Level P & $<0,0001$ \\
\hline
\end{tabular}

Прогнозные значения

Figure 14. The graph of the dependence of the observed values on the predicted values and the quality of the model NSE $=3,17+0,05 * \mathrm{LDH}+1,7 *$ lactate $+4,9 * \mathrm{~S} 100 \mathrm{~B}-0,63 *$ glucose Where:

3,166 - constant

0,052 - regression coefficient of $\mathrm{LDH}$;

1,699 - regression coefficient of lactate;

4,900 - regression coefficient of S100B;

$-0,632$ - regression coefficient of glucose

The results of the regression analysis showed that the variables independently statistically associated with NSE were LDH, lactate, S100B, and blood glucose. In this part of the study, we 


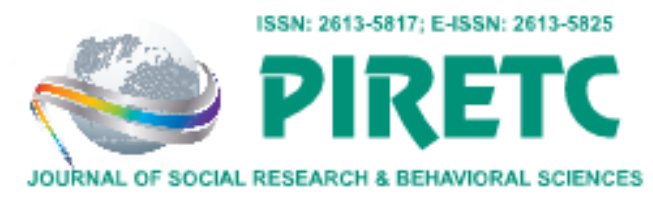

have focused on those variables that are strongly associated with the dependent variable. Differences in the mean value of NSE protein in serum with different outcomes The group with a favorable outcome (GOS 4,5,3) and the group with a poor outcome (GOS 1,2) with a lethal outcome significantly differ in the mean and maximum values of the level of NSE protein in blood serum $(\mathrm{p}=0.05)$. Next, we plotted Kaplan-Meier survival curves for NSE <12.5 ng / ml

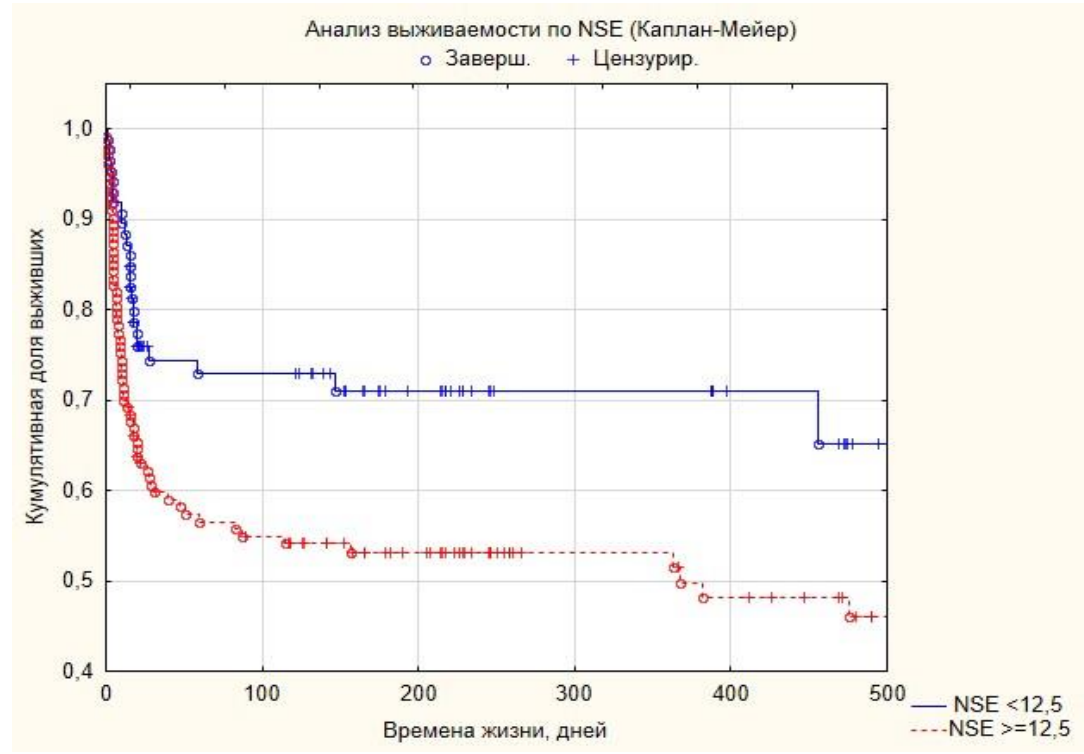

Figure 15. Kaplan-Meier survival curves for NSE $<12.5 \mathrm{ng} / \mathrm{ml}$ and NSE $>12.5 \mathrm{ng} / \mathrm{ml}$

As can be seen from the figure, the cumulative indicator of cases of poor outcome in the group with a level and NSE> $12.5 \mathrm{ng} / \mathrm{ml}$ began to diverge already in the first days of observation. The achieved level of significance according to the log Rank criterion (Mantel Cox) $=0.0062$, the differences in the study groups are significant. Thus, the NSE protein level> $12.5 \mathrm{ng} / \mathrm{ml}$ can serve as a predictor of death in the early stages of the disease.

It was found that the levels of neuron-specific proteins, blood gases and predictors of impaired brain metabolism differentiated among themselves depending on the outcome of the disease. The revealed differences were explained by the biochemical characteristics of cerebral injuries, which, in turn, were determined by their morpho-functional characteristics. The essence of the dominant brain damage is the development of a pathological process in the direction of an increase in cytotoxic edema (edema-swelling) of the brain, an increase in intracranial pressure with possible dislocation and wedging of the brain. In general, the results of the comparison of blood serum indices gave a positive result. They showed that the magnitude of individual neuromarkers can serve as a criterion for the dominance of secondary brain injury.

Discussion: Death rates from traumatic and vascular injury differ in several studies. Some studies also use different temporal methods and parameters to analyze this mortality. Mortality ranges from 13 to $22 \%$ [20]. It has been established that after the primary injury, from the first minutes, secondary brain damage develops, which can continue in subsequent periods for several years due to excessive metabolic, cellular and molecular activity of inflammation [20]. The research results 


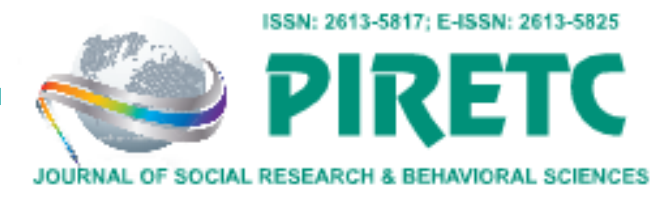

indicate that the immunoenzyme screening of neuron-specific proteins (NSE) makes it possible to assess the degree of damage to the blood-brain barrier and the depth of pathological changes occurring in the nervous system [21]. During the infectious process, immunopathological reactions are triggered in the central nervous system, leading to the activation of T-lymphocytes and an increase in the BBB permeability $[22,23]$. The penetration of the virus into the central nervous system is largely determined by the state of the BBB. Violation of the BBB permeability is accompanied by the release of NSE into the blood.

Determination of NSE and S100 protein in serum and cerebrospinal fluid in the acute period of traumatic and vascular brain damage can serve as an additional criterion for early diagnosis of impaired blood-brain barrier permeability in the acute period of the disease and as a criterion for the restoration of its permeability in the long-term period [24, 25].

The researchers also found that this biomarker reflects the severity of injury based on GCS [26]. Based on this study, it was shown that high NSE levels were significantly different in surviving or deceased subjects with head injuries. The brain damage that causes high levels of NSE can be strongly associated with impaired BBB and ischemia. So, for example, according to [27], postischemic vasospasm usually develops within 3 days after traumatic and vascular lesions. The strength of short-term predictors of mortality is also better than predictors of long-term mortality risks, both in significance of mean differences and in diagnostic power. Another study argued against the results that NSE level could not be a predictor of mortality. The differences were associated with variations in the time of NSE collection in each study, from the time of injury to 84 hours after injury. These studies were carried out heterogeneously in terms of time and methodology, so the results of the study also differ [28]. In this article, we describe the development of a predictive model of increasing complexity based on predictors to predict poor patient outcomes. The model adequately differentiated between patients with poor and good outcomes. The largest amount of prognostic information was contained in the main set of predictors: S100B, GCS, pCO2, glucose and $\mathrm{LDH}$ at admission. These characteristics have already been taken into account in many predictive models [29,30]. Further validation of this estimate is needed, but the required data were insufficiently available in most of the IMPACT studies. Glucose and hemoglobin have been shown to contribute to predicting outcome, although their influence is less than that of other predictors such as age [31]. In intensive care units, intensive treatment of hyperglycemia has been shown to reduce mortality [32]. Early prediction of outcome allows a baseline risk profile to be established for individual patients, thereby providing a reference for assessing the quality of care. Predictive models are especially important for better planning and analysis of RCTs. For example, we can exclude patients with a very good or very poor prognosis [33], perform a covariate adjustment for treatment effect [34,35], and consider other analyzes that lead to increased statistical power [36].

The proposed scales can also assist physicians in their initial assessment of the severity and prognosis of patients with brain damage. However, we note that models can only complement and not replace clinical judgment, although it is unlikely that any clinician has equivalent systematic experience with the thousands of patients that underlie our models. The prognosis should be treated with caution and not used directly to make decisions about limiting treatment [37].

These models can be useful for providing relatives with realistic information about expected outcomes, for quantifying and categorizing the severity of brain injury, for stratifying and correcting covariance in clinical trials, and as a reference for assessing the quality of care. 
VOLUME 17 ISSUE 072021

Thus, early detection and control of the S100B level, as well as simultaneous studies of S100 and NSE, make it possible to identify and confirm the presence of brain damage at an early stage, it is possible to successfully predict secondary brain damage.

Limitations and further study: This study had limitations. The study with a small number of patients was single-center, which limits its validity. Secondly, there were certain difficulties in the process of work associated with the refusal of patients or their relatives from further participation in this study; there was no dynamic long-term follow-up of the studied patients.

This study provides the basis on which further multicenter studies should be built in order to establish generalizability and improve the validity of the results obtained.

Conclusion: 1. The levels of the dependent variable (NSE) and independent variables (S100B, blood glucose, GCS and HB) can be used as multimodal predictors of predicting neurological outcome in patients with acute cerebral pathology. In this study, we were able to predict the quantitative indicator of the NSE $y=0.4292 x+9.58 . R^{2}=0.4292$

2. The proposed mathematical model, which includes the dependent variable (NSE) and independent variables (S100B, blood glucose, GCS and HB) as predictors of poor outcomes, had a cut-off point The best predictive value of the model had a cut-off point of $88.89 \%$, AuROC0.809; Se-51.59\%; Sp-95.06\%; NPV-55.80\%; PPV-94.20\%, which corresponds to the excellent quality of the predictive ability of the mathematical model. The model can be used in everyday practice to identify and reduce the likelihood of a high risk of adverse clinical outcome in patients with acute cerebral pathology.

\section{REFERENCES}

1. Brazinova A, Rehorcikova V, Taylor MS, Buckova V, Majdan M, Psota M, Peeters W, Feigin V, Theadom A, Holkovic L, Synnot A. Epidemiology of Traumatic Brain Injury in Europe: A Living Systematic Review. J Neurotrauma. 2021 May 15;38(10):1411-1440. doi: 10.1089/neu.2015.4126. Epub 2018 Dec 19. PMID: 26537996; PMCID: PMC8082737.

2. Boursin P, Paternotte S, Dercy B, Sabben C, Maïer B. Sémantique, épidémiologie et sémiologie des accidents vasculaires cérébraux [Semantics, epidemiology and semiology of stroke]. Soins. 2018 Sep;63(828):24-27. French. doi: 10.1016/j.soin.2018.06.008. PMID: 30213310.

3. Faiz KW, Rønning OM. Hjerneslag [Stroke]. Tidsskr Nor Laegeforen. 2018 Feb 5;138(3). Norwegian. doi: 10.4045/tidsskr.17.0677. PMID: 29411589.

4. David A, Mari C, Vignaud F, Masson D, Planche L, Bord E, et al. Evaluation of S100B blood level as a biomarker to avoid computed tomography in patients with mild head trauma under antithrombotic medication. 2017; 98: 551-556.

5. Wijanarko F, Alifianto U, Setyono H, Arsika Ramadhana G, Sungkar AA, Saadhi I, Setiawati DA. S100 $\beta$ protein levels as a parameter to assess the clinical development of adult patients with mild traumatic brain injury in Dr. Moewardi Public Hospital, Surakarta. Surg Neurol Int. 2021 Jul 12;12:342. doi: 10.25259/SNI_294_2021. PMID: 34345483; PMCID: PMC8326141. 
6. Adrian H., Martin K., Salla N., Lasse V. Biomarkers of traumatic brain injury: temporary changes in body fluids. eNeuro. 2016; 3 (6): 294-9. https://doi.org/10.1523/ENEURO.0294-16.2016 PMid: 28032118 PMCid: PMC5175263.

7. Mercier E., Butin A., Lauzier F., Fergusson D.A., Simard J. F., Zarychansky R. et al. Prognostic value of S-100beta protein for prognosis in patients with moderate and severe traumatic brain injury: systematic review and meta-analysis. BMJ. 2013; 346: 1757-9. https://doi.org/10.1136/bmj.f1757 PMid: 23558282.

8. Pfortmueller CA, Drexel C, Krahenmann-Muller S, Leichtle AB, Fiedler GM, Lindner G, et al. Concentrations of S-100 B are a prognostic factor of reduced survival in patients with serious trauma, regardless of traumatic brain injury. PloS One. 2016; 11 (3): 1-5. https://doi.org/10.1371/journal.pone.0152822 PMid: 27031106 PMCid: PMC4816449.

9. Murillo-Cabezas F., Mu-oz-sAnchez M.A., Rincon-Ferrari M.D., etc. Prognostic value of the time course of the $\mathrm{S} 100 \mathrm{~B}$ eta protein in severe post-acute brain injury: a prospective and observational study. Brain Inj. 2010; 24 : 609-19. https://doi.org/10.3109/02699051003652823 PMid: 20235763.

10. Tokshilykova, A.B., Sarkulova, Z.N., Kabdrakhmanova, G.B. et al. Neuron-Specific Markers and their Correlation with Neurological Scales in Patients with Acute Neuropathologies. Journal of molecular Neuroscience (2020). https://doi.org/10.1007/s12031-020-01536-5.

11. Rainey T., Lesko M., Sachko R., Lecky F., Childs S. Predicting the outcome after severe traumatic brain injury using the S100B serum biomarker: results using a single time point (24 hours). $\quad$ Resuscitation. $2009 ; \quad 80 \quad$ : $341-5$. https://doi.org/10.1016/j.resuscitation.2008.11.021 PMid: 19150161.

12. Chi Y. L. et al. Evaluation of the postoperative cognitive dysfunction in elderly patients with general anesthesia //Eur Rev Med Pharmacol Sci. - 2017. - T. 21. - №. 6. - C. 134654.

13. Hong SK, Kim JH, Starenki D, Park JI. Autophagy sensitivity of neuroendocrine lung tumor cells. Int J Oncol. 2013 Dec;43(6):2031-8. doi: 10.3892/ijo.2013.2136. Epub 2013 Oct 11. PMID: 24126619; PMCID: PMC3834067.

14. Xu CM, Luo YL, Li S, Li ZX, Jiang L, Zhang GX, Owusu L, Chen HL. Multifunctional neuron-specific enolase: its role in lung diseases. Biosci Rep. 2019 Nov 29;39(11):BSR20192732. doi: 10.1042/BSR20192732. PMID: 31642468; PMCID: PMC6859115.

15. Hagmeyer S, Romão MA, Cristóvão JS, Vilella A, Zoli M, Gomes CM, Grabrucker AM. Distribution and Relative Abundance of S100 Proteins in the Brain of the APP23 Alzheimer's Disease Model Mice. Front Neurosci. 2019 Jun 20;13:640. doi: 10.3389/fnins.2019.00640. PMID: 31281238; PMCID: PMC6596341.

16. Lasek-Bal A, Jedrzejowska-Szypulka H, Student S, Warsz-Wianecka A, Zareba K, Puz P, Bal W, Pawletko K, Lewin-Kowalik J. The importance of selected markers of inflammation and blood-brain barrier damage for short-term ischemic stroke prognosis. $\mathrm{J}$ Physiol Pharmacol. 2019 Apr;70(2). doi: 10.26402/jpp.2019.2.04. Epub 2019 Jul 22. PMID: 31356182.

17. Goyal A., Falla M.D., Niyonkuru S., Amin K., Fabio A., Birger R.P., Wagner A.K. S100b as a prognostic biomarker in predicting outcomes for patients with severe brain injury. $\mathrm{J}$ 
Neurotrauma. 2013; 30 (11): 946-57. https://doi.org/10.1089/neu.2012.2579 PMid: 23190274 PMCid: PMC3684103

18. Kellermann I, Kleindienst A, Horan, Buchfelder M, Bronner S. Concentrations of early CSF and S100B serum for predicting outcomes in traumatic brain injury and subarachnoid $\begin{array}{llll}\text { hemorrhage. Clin Neurol } \quad \text { Neurosurg. } & \text { 2016; }\end{array}$ https://doi.org/10.1016/j.clineuro.2016.04.005 PMid: 27101088.

19. Olivecrona M, Rodling-Wahlström M, Naredi S, Koskinen LO. S-100В и нейронспецифическая энолаза являются плохими предикторами исхода при тяжелой черепно-мозговой травме, леченной таргетной терапией внутричерепным давлением. J Neurol Neurosurg Psychiatry. 2009; 80 (11): $1241-$ 7. https://doi.org/10.1136/jnnp.2008.158196 PMid: 19602473.

20. Ballesteros MA, Rubio-Lopez MI, San Martín M, Padilla A, López-Hoyos M., Llorca J, Mi-ambres E. S100B levels from the jugular vein bulb as a biomarker of poor prognosis in patients with severe acute brain injury . J Neurol Sci. 2018; 385 : 109-14. https://doi.org/10.1016/j.jns.2017.12.017 PMid: 29406887.

21. Anderson BJ, Reilly JP, Shashaty MGS, Palakshappa JA, Wysoczanski A, Dunn TG, Kazi A, Tommasini A, Mikkelsen ME, Schweickert WD, Kolson DL, Christie JD, Meyer NJ. Admission plasma levels of the neuronal injury marker neuron-specific enolase are associated with mortality and delirium in sepsis. J Crit Care. 2016 Dec;36:18-23. doi: 10.1016/j.jcrc.2016.06.012. Epub 2016 Jun 23. PMID: 27546742; PMCID: PMC5096992.

22. Cheng F, Yuan Q, Yang J, Wang W, Liu H. The prognostic value of serum neuronspecific enolase in traumatic brain injury: systematic review and meta-analysis. PLoS One. 2014 Sep 4;9(9):e106680. doi: 10.1371/journal.pone.0106680. PMID: 25188406; PMCID: PMC4154726.

23. Mattos JD, Campos MO, Rocha MP, Mansur DE, Rocha HNM, Garcia VP, Batista G, Alvares TS, Oliveira GV, Souza MV, Videira RLR, Rocha NG, Secher NH, Nóbrega ACL, Fernandes IA. Human brain blood flow and metabolism during isocapnic hyperoxia: the role of reactive oxygen species. J Physiol. 2019 Feb;597(3):741-755. doi: 10.1113/JP277122. Epub 2018 Dec 26. PMID: 30506968; PMCID: PMC6355640.

24. Czupryna P, Grygorczuk S, Pancewicz S, Świerzbińska R, Zajkowska J, Krawczuk K, Dunaj J, Filipiuk J, Kruszewska E, Borawski K, Moniuszko-Malinowska A. Evaluation of NSE and S100B in patients with tick-borne encephalitis. Brain Behav. 2018 Dec;8(12):e01160. doi: 10.1002/brb3.1160. Epub 2018 Nov 22. PMID: 30468006; PMCID: PMC6305942.

25. Lindblad C, Nelson DW, Zeiler FA, Ercole A, Ghatan PH, von Horn H, Risling M, Svensson M, Agoston DV, Bellander BM, Thelin EP. Influence of Blood-Brain Barrier Integrity on Brain Protein Biomarker Clearance in Severe Traumatic Brain Injury: A Longitudinal Prospective Study. J Neurotrauma. 2020 Jun 15;37(12):1381-1391. doi: 10.1089/neu.2019.6741. Epub 2020 Mar 6. PMID: 32013731; PMCID: PMC7249468.

26. Gradisek P, Osredkar J, Korsika M, Kremzar B. A model with multiple indicators of longterm mortality in traumatic brain injury. Brain Ini. 2012; 26 (12): 1472-81. https://doi.org/10.3109/02699052.2012.694567 PMid: 22721420

27. Tum I., Kshih L., Yendzheyevskaya-Shpulka H., Levin-Kovalik Y.L. Serum levels of S100B protein and neuron-specific enolase are associated with mortality in critically ill patients. Biochimica Polonica. 2017; 64 : 16-9. https://doi.org/10.18388/abp.2017_1619. 
28. Shakeri M, Mahdkhah A, Panahi F. S100B Protein as a Post-traumatic Biomarker for Prediction of Brain Death in Association With Patient Outcomes. Arch Trauma Res. 2013 Aug;2(2):76-80. doi: 10.5812/atr.8549. Epub 2013 Aug 1. PMID:24396798; PMCID: PMC3876553

29. Kang C, Jeong W, Park JS, You Y, Min JH, Cho YC, Ahn HJ. Comparison of Prognostic Performance between Neuron-Specific Enolase and S100 Calcium-Binding Protein B Obtained from the Cerebrospinal Fluid of Out-of-Hospital Cardiac Arrest Survivors Who Underwent Targeted Temperature Management. J Clin Med. 2021 Apr 6;10(7):1531. doi: 10.3390/jcm10071531. PMID: 33917473; PMCID: PMC8038742.

30. Perel P, Edwards P, Wentz R, Roberts I. Systematic review of prognostic models in traumatic brain injury. BMC Medical Informatics and Decision Making. 2006 Nov;6:38. DOI: 10.1186/1472-6947-6-38. PMID: 17105661; PMCID: PMC1657003.

31. Nino A. Mushkudiani, Chantal W.P.M. Hukkelhoven, Adrián V. Hernández, Gordon D. Murray, Sung C. Choi, Andrew I.R. Maas, Ewout W. Steyerberg, A systematic review finds methodological improvements necessary for prognostic models in determining traumatic brain injury outcomes, Journal of Clinical Epidemiology,Volume 61, Issue 4,2008,Pages 331-343,ISSN 0895-4356,https://doi.org/10.1016/j.jclinepi.2007.06.011.

32. Rodriguez-rOdriguez A., Higuera-gUerrero J. J., Gordillo-Escobar E., EnamoradoEnamorado J., Hernandez-Garcia S., Ruiz de Azua-Lopez Z., Vilchez-Arenas A., Guerrero J. M., Murillo-100-Cabezas and Ne urlo 100-Cabezas and -specific enolase as predictors of mortality in patients with severe traumatic brain injury. Neurol Res. 2016; 38 (2): 130 7. https://doi.org/10.1080/01616412.2016.1144410 PMid: 27078699.

33. Dulf D, Coman MA, Tadevosyan A, Chikhladze N, Cebanu S, Peek-Asa C. A 3-Country Assessment of Traumatic Brain Injury Practices and Capacity. World Neurosurg. 2021 Feb;146:e517-e526. doi: 10.1016/j.wneu.2020.10.115. Epub 2020 Oct 27. PMID: 33127569; PMCID: PMC7897235.

34. Chalos V, A van de Graaf R, Roozenbeek B, C G M van Es A, M den Hertog H, Staals J, van Dijk L, F M Jenniskens S, J van Oostenbrugge R, H van Zwam W, B W E M Roos Y, B L M Majoie C, F Lingsma H, van der Lugt A, W J Dippel D; MR CLEAN-MED investigators. Multicenter randomized clinical trial of endovascular treatment for acute ischemic stroke. The effect of periprocedural medication: acetylsalicylic acid, unfractionated heparin, both, or neither (MR CLEAN-MED). Rationale and study design. Trials. 2020 Jul 14;21(1):644. doi: 10.1186/s13063-020-04514-9. PMID: 32665035; PMCID: PMC7362523.

35. Alcock S, Batoo D, Ande SR, Grierson R, Essig M, Martin D, Trivedi A, Sinha N, Leeies M, Zeiler FA, Shankar JJS. Early diagnosis of mortality using admission CT perfusion in severe traumatic brain injury patients (ACT-TBI): protocol for a prospective cohort study. BMJ Open. 2021 Jun 9;11(6):e047305. doi: 10.1136/bmjopen-2020-047305. PMID: 34108167; PMCID: PMC8191612.

36. Nelson LD, Brett BL, Magnus BE, Balsis S, McCrea MA, Manley GT, Temkin N, Dikmen S. Functional Status Examination Yields Higher Measurement Precision of Functional Limitations after Traumatic Injury than the Glasgow Outcome Scale-Extended: A Preliminary Study. J Neurotrauma. 2020 Feb 15;37(4):675-679. doi: 10.1089/neu.2019.6719. Epub 2019 Nov 13. PMID: 31663425; PMCID: PMC7045351. 
37. Zampieri FG, Granholm A, Møller MH, Scotti AV, Alves A, Cabral MM, Sousa MF, Balieiro HM, Hortala CC Jr, Filho EMR, Perecmanis E, de Magalhães Menezes MA, Moreira CEN, Moralez GM, Bafi AT, de Carvalho CB, Salluh JIF, Bozza FA, Perner A, Soares M. Customization and external validation of the Simplified Mortality Score for the Intensive Care Unit (SMS-ICU) in Brazilian critically ill patients. J Crit Care. 2020 Oct;59:94-100. doi: 10.1016/j.jcrc.2020.05.016. Epub 2020 May 29. PMID: 32585439. 


\title{
IMMUNOHISTOCHEMICAL FEATURES IN SOFT TISSUE SARCOMAS
}

\author{
Ahliman Amiraslanov, Sevinj Abdiyeva, Azer Amiraslanov, Elnur Ibrahimov, \\ Habil Muradov \\ Azerbaijan Medical University, Department of Oncology, Azerbaijan.
}

\section{ABSTRACT}

Sarcomas are relatively rare, accounting for only $1 \%$ of all adult malignancies and $15 \%$ of childhood malignancies [2]. According to the World Health Organization (WHO), the group of soft tissue sarcomas includes more than 100 different histological subtypes [3]. According to the recommmendations of the WHO to improve the accuracy of diagnosis in soft tissue sarcoma, the traditional histopathological examination should be supplemented with immunohistochemical and molecular methods [1]. It was carried out immunohistochemical research of CD31 receptor of Vascular Endothelial Growth Factor (VEGF) in 129 patients with STS.

The age range of patients is on average 14-77 years with a peak in the age of 50-59 years. The most common reason for initial visit to a medical institution was palpable tumor (100\%). It was studied the following correlative interdependences:

It was determined that histodifferentiation of tumour is in inverse correlation with expression CD31 receptor. Distinctions of expression level of CD31 are shown, depending on the degree of tumor differentiation, presence or absence of its spontaneous necrotization, limphoid infiltration of pathological nidus and amount of vessels in tumor tissue. That is as high the degree of histological differentiation of tumour as low the level of expression CD31 receptor $\left(\chi^{2}=35,4\right.$; $\mathrm{p}<0,001 ; \mathrm{p}=-0,322)$. In FHTof ST is exposed inverse dependence between expression CD31 endotelial cells with spontaneous necrosis and lymphoid infiltration. As more the size and foci of spontaneous necrosis $\left(\chi^{2}=67,1 ; p<0,001 ; p=-0,473\right)$ and lymphoid infiltration $\left(\chi^{2}=46,1 ; p<0,001\right.$; $\mathrm{p}=-0,346)$, as low the level of expression CD31 receptor. It was found that the high level of espression CD31 receptor is in direct correlation with metastasis $\left(\chi^{2}=18,6 ; p=0,42 ; p<0,001\right)$ and recurrence $\left(\chi^{2}=9,43 ; p=0,30 ; p<0,01\right)$ of the process. Studied modern approaches to the diaqnostics and treatment of malignancies. One such approach is "Oncology Control", which means minimizing the risk of recurrence at the local and systemic level. Following treatment, follow-up should include history and physical examination accompanied by imaging (Ultrasound or MRI) every 3 to 6 month for 2 to 3 years, and then every 6 to 12 months thereafter to asses for recurrence. So in high positivity of CD31 receptor is exposed unfavourable prognosis in patients with STS.

Summarizing before said we have come to the conclusion that immune-histo-chemical investigation of CD31 receptor of VEGF has important prognostical meaning in patients STS.

This work was supported by the Science Development Foundation under the President of the Republic of Azerbaijan. Grant № ЕИФ-2011-1(3)-82/45/3. 


\section{REFERENCES}

1) Benberin V.V., Bayzakov B.T., Shanazarov N.A., Zinchenko S.V. [Soft tissue sarcoma; a modern view to the problem][Avicenna Bulletin].2019:21(2):291-7. Available from/http//dx.doi.org/10.25005/2074-0581-2019-21-2-291-297.

2) Farid M.N., Geow J. Sarcomas associated with genetic cancer predisposition syndromes : a review.Oncologist 2016;21:1002-1013.

3) Fletcher C.M., Bridge J.A., Hogendoorn P.W., Lyon M.F. World Healh Organization classification of tumours of soft tissue and bone. $4^{\text {th }}$ ed. Lyon, France: IARC Press: 2013. p.25-67. 


\section{THE LEVEL OF S100 IN BLOOD SERUM AS A PROGNOSTIC FACTOR OF OUTCOME IN SECONDARY BRAIN LESIONS}

\section{Ainur Tokshilykova, Zhanslu Sarkulova, Gulnar Kabdrakhmanova, Marat Sarkulov, Aigul Utepkaliyeva, Botagoz Kalieva}

West Kazakhstan Marat Ospanov medical university, Kazakhstan.

Email: Ainur.t_83@mail.ru

\section{ABSTRACT}

This study is devoted to the study of the prognostic value of neuron-specific markers of the brain and indicators of the outcome of brain damage.

The purpose of the study. To study the prognostic role of serum S100 as a predictor of mortality in vascular and traumatic brain injuries.

Materials and methods. A prospective cohort study involving 219 patients. In the blood serum, neuron-specific markers (S100, NSE) and glucose, acid-base state and gas composition of arterial blood were obtained during follow-up periods: at admission, on the 3rd, 5th and 7th days of patients' stay in the intensive care unit.

Results. The most significant risk factor for an unfavorable outcome is the marker S100 with a cut-off point of $0.2 \mathrm{mcg} / \mathrm{l}$. The results of the analysis indicate the presence of a statistically significant direct relationship between $\mathrm{S} 100>0.2 \mathrm{mcg} / \mathrm{l}$ and NSE $\geq 18.9 \mathrm{ng} / \mathrm{ml}$ compared to other variables, while the chance ratio (OR) is 11.9 (95\%CI:3.2927-1.6693;). With an increase in blood sugar above $7.4 \mathrm{mmol} / \mathrm{l}$, the OR is 3.82 (95\% CI: 2.1289- 0.5539;); with a Glasgow scale below 13 points, the OR is 3.69 (95\% CI: 2.1316-0.4819;); with an increase in pCO2 <43.5 mm Hg, the OR was 3.15 (95\% CI: 1.8916- 0.4062;). The measure of certainty of the obtained model according to the criterion of pseudo R2 Nagelkerke is 263.5, which corresponds to the excellent quality of the predictive ability of the mathematical model. The developed prognostic model, including the dependent variable S100 and independent variables as predictors of a poor outcome of NSE, pCO2, GCS and $\mathrm{Hb}$, reached a cut-off point of $84.51 \%$, AUC - 0.88 with high levels of sensitivity and specificity: $91.89 \%$ and $64.14 \%$, respectively. This model can be used to predict the outcome in patients with acute cerebral pathology.

Keywords: strokes, traumatic brain injuries, neuron-specific markers, diagnostic and prognostic criteria, stroke outcome.

\section{REFERENCES}

1. Brazinova A, Rehorcikova V, Taylor MS, Buckova V, Majdan M, Psota M, Peeters W, Feigin V, Theadom A, Holkovic L, Synnot A. Epidemiology of Traumatic Brain Injury in Europe: A Living Systematic Review. J Neurotrauma. 2021 May 15;38(10):1411-1440. doi: 10.1089/neu.2015.4126. Epub 2018 Dec 19. PMID: 26537996; PMCID: PMC8082737.

2. Boursin P, Paternotte S, Dercy B, Sabben C, Maïer B. Sémantique, épidémiologie et sémiologie des accidents vasculaires cérébraux [Semantics, epidemiology and semiology of stroke]. Soins. 2018 Sep;63(828):24-27. French. doi: 10.1016/j.soin.2018.06.008. PMID: 30213310. 
3. Faiz KW, Rønning OM. Hjerneslag [Stroke]. Tidsskr Nor Laegeforen. 2018 Feb 5;138(3). Norwegian. doi: 10.4045/tidsskr.17.0677. PMID: 29411589.

4. Dadas A, Washington J, Marchi N, Janigro D. Improving the clinical management of traumatic brain injury through the pharmacokinetic modeling of peripheral blood biomarkers. Fluids Barriers CNS. 2016 Nov 30;13(1):21. doi: 10.1186/s12987-016-0045y. PMID: 27903281; PMCID: PMC5402680.

5. Wijanarko F, Alifianto U, Setyono H, Arsika Ramadhana G, Sungkar AA, Saadhi I, Setiawati DA. S100 $\beta$ protein levels as a parameter to assess the clinical development of adult patients with mild traumatic brain injury in Dr. Moewardi Public Hospital, Surakarta. Surg Neurol Int. 2021 Jul 12;12:342. doi: 10.25259/SNI_294_2021. PMID: 34345483; PMCID: PMC8326141.

6. Adrian H., Martin K., Salla N., Lasse V. Biomarkers of traumatic brain injury: temporary changes in body fluids. eNeuro. 2016; 3 (6): 2949. https://doi.org/10.1523/ENEURO.0294-16.2016 PMid: 28032118 PMCid: PMC5175263.

7. Mercier E., Butin A., Lauzier F., Fergusson D.A., Simard J. F., Zarychansky R. et al. Prognostic value of S-100beta protein for prognosis in patients with moderate and severe traumatic brain injury: systematic review and meta-analysis. BMJ. 2013; 346: 17579. https://doi.org/10.1136/bmj.f1757 PMid: 23558282.

8. Pfortmueller CA, Drexel C, Krahenmann-Muller S, Leichtle AB, Fiedler GM, Lindner G, et al. Concentrations of S-100 B are a prognostic factor of reduced survival in patients with serious trauma, regardless of traumatic brain injury. PloS One. 2016; 11 (3): 15. https://doi.org/10.1371/journal.pone.0152822 PMid: 27031106 PMCid: PMC4816449.

9. Murillo-Cabezas F., Mu-oz-sAnchez M.A., Rincon-Ferrari M.D., etc. Prognostic value of the time course of the S100B eta protein in severe post-acute brain injury: a prospective and observational study. Brain Inj. 2010; 24: 609-19. https://doi.org/ 10.3109/02699051003652823 PMid: 20235763.

10. Tokshilykova, A.B., Sarkulova, Z.N., Kabdrakhmanova, G.B. et al. Neuron-Specific Markers and their Correlation with Neurological Scales in Patients with Acute Neuropathologies. Journal of molecular Neuroscience (2020). https://doi.org/10.1007/s12031-020-01536-5.

11. Rainey T., Lesko M., Sachko R., Lecky F., Childs S. Predicting the outcome after severe traumatic brain injury using the $\mathrm{S} 100 \mathrm{~B}$ serum biomarker: results using a single time point (24hours). Resuscitation.2009;80:341-5. https://doi.org/10.1016/j.resuscitation.

2008.11.021 PMid: 19150161.

12. Goyal A., Falla M.D., Niyonkuru S., Amin K., Fabio A., Birger R.P., Wagner A.K. S100b as a prognostic biomarker in predicting outcomes for patients with severe brain injury. $\mathbf{J}$ Neurotrauma. 2013; 30 (11): 946-57. https://doi.org/ 10.1089/neu.2012.2579 PMid: 23190274 PMCid: PMC3684103 


\section{EDITORIAL BOARD}

Honorary Editors

Archil Prangishvili

Georgian Technical University. Doctor of Technical Sciences. Full Professor.

Avtandil Silagadze

Correspondent committee-man of National Academy of Georgia. Tbilisi University of International Relationships. Doctor of Economical Sciences. Full Professor.

Badri Gechbaia

Batumi Shota Rustaveli State University. Head of Business Administration Department. PhD in Economics,

Associate Professor.

Davit Narmania

Tbilisi State University (TSU), Chair of Management and Administration Department. Professor.

Lamara Qoqiauri

Georgian Technical University. Member of Academy of Economical Sciences. Member of New York Academy of Sciences.

Director of first English school named "Nino". Doctor of Economical Sciences. Full Professor.

Lia Eliava

Kutaisi University.Economic expert in the sphere of economy and current events in financial sector.Full Professor.

$\mathrm{PhD}$ in Business Administration.

Liana Ptaschenko

Poltava National Technical University named Yuri Kondratyuk. Doctor of Economical Sciences. Professor

Nino Didbaridze

Microbiology and Immunology Department. Immunologi Direction. Tbilisi State Medical University. PhD MD.

Paata Koguashvili

Georgian Technical University. Doctor of Economical Sciences. Full Professor. Academician. Member of Georgia Academy of

Sciences of Agriculture.

Sergei S. Padalka

Doctor of Historical Sciences, Professor, Senior Researcher at the Department of Contemporary History and Policy at the Institute of History of Ukraine National Academy of Sciences of Ukraine.

Tamar Didbaridze

Tbilisi State Medical University, First University Clinic. PhD in MD.

Zurab Khonelidze

Sokhumi State University. Doctor of Political Sciences. Professor.

Honorary editorial board members:

Agaheydar Seyfulla Isayev

Azerbaijan State Oil Academy. Doctor of Economical Sciences. Professor.

Jacob Meskhia

Tbilisi State University. Faculty of Economics and Business. Full Professor. 


\section{INTERNATIONAL ADVISORY AND REVIEWER TEAM}

\section{Australia}

Shahid Khan

Monash Business School. Sessional Lecturer. PhD in Management.

Vikash Ramiah

UNISA School of Commerce. Associate Professor. PhD in Applied Finance.

\section{Azerbaijan}

Abbas İsmayılov

Azerbaijan State Agricultural University. Associate Professor. PhD in Biology Science.

Almaz Mehdiyeva

Azerbaijan State Oil and Industry University.Associate Professor. PhD in TS

Amir V. Aliyev

Ministry of Health of Azerbaijan Republic Lung Diseases Department. Guba District Central Hospital Head

of Department. PhD of Medicine

Aytekin Hasanova

Azerbaijan Medical University. I Preventive Medicine Faculty. Deputy of Dean. PhD in Medical Biology.

Araz Manucheri-Lalen

Associated Professor, PhD Department of Psychiatry, Azerbaijan Medical University.

Arif M. Mammad-Zada

Baku "Geotechnological problems of oil, gas and chemistry", Scientific Research Institute, Professor, Chief Researcher. DS.

Azer K. Mustafayev

Turan Medical Clinic. Cardiologist. PhD in Medicine. Azerbaijan.

Beykas Seyfulla Xidirov

Azerbaijan State Oil and Industrial University. Head of department. Doctor of Economical Sciences

Djamil Alakbarov

A researcher at the Research Institute for Lung Diseases. PhD in medicine. Azerbaijan

Elchin Suleymanov

Baku Engineering University. Associate Professor of Department Finance. PhD in Economy.

Elmira Valiyeva

Azerbaijan State Agrarian University Senior teacher of the Chair of Lnguages.

Elshan Mahmud Hajizade

Cabinet of Ministers of Azerbaijan Republic. Head of department. Doctor of Economic Science.Professor.

Emin Mammadzade

Institute of Economics of ANAS. Economic institute. Phd in Economy. Associate professor.

Farda Imanov

ANAS. Georgrapy Institute. Doctor of Georgraphy Sciences. Professor.

Garib Mamedov

National Academy of Sciences of Azerbaijan Republic. Academician-secretary of the Department of Agrarian Sciences of ANAS,

Academician of ANAS. Doctor of Biolgical Sciences.

Heyder Guliyev

Azerbaijan State Agricultural University. English Teacher. PhD in Philology

Ibrahim Gabibov

Azerbaijan State Oil and Industrial University. Doctor of Technical Sciences. Professor

Jamala Mursalova

Azerbaijan National Academy of Sciences. Genetic Resources Institute. PhD BS.

Lala Bekirova

Azerbaijan State Oil and Industrial University. Azerbaijan National Avation Academy. PhD.TS

Leyla I. Djafarova

Clinic "Medium" Baku. Doctor of Medical Sciences. Professor

Mahmud Hajizade

Sector Director of State Fund for Information Technology Development of the Ministry of Communications and High Technologies of the Republic of Azerbaijan, Ministry of Transport, Communications and High Technologies of the Republic of Azerbaijan.

Naila Quliyeva

Azerbaijan Medical University. Assistant in "Immunology" Program at Paediatrics Diseases Department. Docent and Academic

Manager in "Allergology and Immunology" Department.

Rafig Gurbanov

Azerbaijan State Oil and Industrial University. Doctor of Technical Sciences. Professor

Ramiz Gurbanov

Azerbaijan State Oil and Industrial University. Doctor of Technical Sciences. Professor

Ramiz Mammadov

ANAS. Giography Institute. Doctor of Technical Sciences. Professor. Academician. 
Rashad G. Abishov

Dental Implant Aesthetic Center Harbor Hospital, Azerbaijan State Doctors Improvement Institute. PhD. Azerbaijan.

Rena Gurbanova

Azerbaijan State Oil and Industrial University. Associate Professor. PhD in Chemistry.

Sadagat V. Ibrahimova

Azerbaijan State Oil and Industrial University. Academician Doctor of Economical Sciences. PhD

Samira Mammadova

Sumgayit State University. Senior Teacher of History and its teaching methodology in History Faculty. PhD in History.

Sayyara Ibadullayeva

Institute of Botany. National Academy of Sciences. Professor. PhD in Biological Sciences.

Sevinj Mahmudova

Azerbaijan State Agrarian University. PhD. Researcher.

Tarbiz Nasrulla Aliyev

Innovation Center of National Academy of Azerbaijan Republic. The deputy of director. Doctor of Economical

Sciences.Professor

Tariel Omarov

Azerbaijan Medical University. Department of surgical diseases. PhD in Medicine

Tofig Ahmadov

Azerbaijan State Oil and Industrial University. Doctor of Geology and Mineralogy Sciences. Professor

Tofig Yusif Baharov

Azerbaijan State Oil Company.Scientific Research Institute.Head of department. Doctor of Geology and Mineralogy Sciences

Tofig Samadov

Azerbaijan State Oil and Industrial University. Doctor of Technical Sciences. Professor.

Tubukhanum Gasimzadeh

Azerbaijan National Academy of Sciences. Institute of Dendrology of Azerbaijan NAS. Leading researcher PHD in Biological

Sciences, Associate Professor.

Vusal Ismailov

"Caspian International Hospital". Orthopedics Traumatology Expert. MD. Azerbaijan.

Zakir Aliyev

RAPVHN and MAEP. PhD in Agricultural Sciences, Professor of RAE academician.

Zakir Eminov

ANAS. Giography Institute. Doctor of Georgraphy Sciences. Associate Professor.

\section{Bahrain}

Osama Al Mahdi

University of Bahrain, Bahrain Teachers College. Assistant Professor. PhD, Elementary Education and Teaching

\section{Bangladesh}

Muhammad Mahboob Ali

Daffodil International University. Department of Business Administration . Professor.

\section{Belarus}

Tanua Teterinets

Belarusian State University of Agricultural Technology. Doctor of Economical Sciences. Associate Professor.

Vladimir Yanchuk

Belarus State University. Professor. Academy of Postgraduate Education. PhD in Social Psychology.

\section{Bosna \& Hercegovina}

Igor Jurčić

Head of marketing Business group for VSE/SME. Telecommunication Business and Management.

Ratko Pavlovich

University of East Sarajevo. Faculty of Physical Education and Sport. Full Professor. PhD in Sport Sciences.

\section{Brazil}

Paulo Cesar Chagas Rodrigues

Federal Institute of Education, Science and Technology of Sao Paulo. Professor. PhD in Mechanical Engineering.

\section{Bulgaria}

Desislava Stoilova

South-West University “ Neofit Rilski”. Vice Dean of Faculty of Economics. Associate Professor. PhD in Finance.

Eva Tsvetanova

Tsenov Academy of Economics, Svishtov, Bulgaria Department of Strategic Planning. Head assistant professor. PhD in Economy. 


\section{VOLUME 17 ISSUE 072021}

JOURNAL OF SOCIAL RESEARCH \& BEHAVIORAL SCIENCES

Jean-François Rougè

University of Technology, Sofia. PhD in Business law

Milena Kirova

Sofia University “St. Kliment Ohridski”. Professor. PhD in Philology.

\section{Croatia}

Dragan Čišić

University of Rijeka. Faculty of Maritime Studies. Full professor. PhD in Logistics, e-business.

\section{Egypt}

Abdelbadeh Salem

Professor at Faculty of Computer and Information Science, Ain Shams University.

Neyara Radwan

King Abdul-Aziz University. Jeddah. KSA. Business Administration Department. Faculty of Economics and Administration. Assistant Professor. Suez Canal University. Mechanical Department. Faculty of Engineering. Assistant Professor.

\section{France}

Michael Schaefer

L'Ässociation 1901 SEPIKE International, Président at SEPIKE International. PhD of Economical Sciences

\section{Georgia}

Anzor G. Abralava

Georgian Technical University. Doctor of Economical Sciences. Full Professor

Dali Sologashvili

State University named Akaki Tsereteli. Doctor of Economical Sciences. Full Professor

Dali Osepashvili

Professor of Journalism and Mass Communication TSU (Tbilisi State University), Head MA Program "Media and New Technology"

Davit Tophuria

Tbilisi State Medical University. Head of International Students Academic Department, Associate Professor. PhD in HNA.

Eka Avaliani

International Black Sea University. Associate Professor. PhD in History.

Eka Darchiashvili

Tbilisi State University named after Sv. Grigol Peradze. Assistant of professor. PhD in BA.

Ekaterine Maghlakelidze

The University of Georgia, Associated professor, Business, Economics and Management School.

Enene Menabde-Jobadze

Georgian Technical University. Academical Doctor of Economics.

Eter Bukhnikashvili

Dental clinic "NGM-Innovation Dental". The doctor-stomatologist. PhD in Medicine.

Evgeni Baratashvili

Georgian Technical University. Head of Economic and Business Department. Doctor of Economical Sciences. Full Professor

George Jandieri

Georgian Technical University; Chief scientist, Institute of Cybernetics of the Georgian Academy. Full Professor

George Malashkhia

Georgian Technical University. Doctor of Economical Sciences. Full Professor.

Giorgi Kepuladze

Akaki Tsereteli State University, Faculty of Business, Law and Social Sciences, PhD in Economics. Invited teacher.

Gulnara Kiliptari

Tbilisi StateMedical University. Head of ICU department. Associate professor.

lamze Taboridze

Scientific Center of the Humanitarian Educational University, Head, PhD in Medicine. Associate professor.

Irma Makharashvili

Caucasus International University. Dean of Business Faculty. Doctor of Economical Sciences. Full Professor

Ketevan Goletiani

Batumi Navigation Teaching University. Dean of Logistics Faculty.Batumi Shota Rustaveli State University. Doctor TS, Professor.

Larisa Korghanashvili

Tbilisi State University (TSU) named Ivane Javakhishvili. Full Professor

Larisa Takalandze

Sokhumi State University, Faculty of Economic and Business. Doctor of Economic Sciences.

Lia Davitadze

Batumi Shota Rustaveli State University. Higher Education Teaching Professional. PhD in Educational Sciences.

Lia Matchavariani

Tbilisi State University (TSU) named Ivane Javakhishvili. Full Professor, Faculty of Exact \& Natural Sciences (Geography Dep.)

\section{PIRETC}


Loid Karchava

Doctor of Business Administration, Association Professor at the Caucasus International University, Editor-in-Chief of the international Scientific Journal "Akhali Ekonomisti" (The New Economist)

Maia Kapanadze

Georgian State University named Javaxashvili. Doctor of Economical Sciences. Associate Professor.

Maia Matoshvili

Tbilisi State Medical University. The First University Clinic. Dermato-Venereologist. Assistant Professor. PhD in DAPS.

Mariam Darbaidze

Davit Aghmashenebeli National Defense Academy of Georgia. The Head of Education Division. PhD in Biology.

Mariam Kharaishvili

Ilia State University. Asistent Professor. PhD MD.

Mariam Nanitashvili

Executive Director - Wise Development LTD (Training Centre). Associated Professor at Caucasus University. PhD in Economics Nana Shoniya

State University of Kutaisi named Akakhi Tsereteli. Doctor of Economical Sciences. Full professor

Natia Beridze

LEPL National Environmental Agency of Georgia, Invited Expert at International Relations and PR Division. PhD in Political Science.

Nelli Sichinava

Akaki Tsereteli State Universiry . Associate. Professor. PhD

Nino Gogokhia

Tbilisi State Medical University. Head of Laboratory the First University Clinic. Professor.

Nino Museridze

GGRC Georgian-German Center for Reproductive Medicine, Owner and Clinical Director. The Doctor of Medicine, Full Professor.

Nino Pirtskhelani

Associated Professor of Department of Molecular and Medical Genetics of Tbilisi State Medical University.

Omari Omarimu

Tbilisi State University named Iv. Javakhishvili. Doctor of Chemical Sciences Professor

Rati Abuladze

St. Andrew the first-called Georgian University of the Patriarchate of Georgia. Faculty of Economics and Eusiness Edministration.

Manager of the Faculty Quality Assurance Office. PhD in Business Administration.

Rusudan Kutateladze

Georgian Technical University. Doctor of Economical Sciences. Full Professor

Rusudan Sujashvili

New Vision University. School of Medicine. Professor,

Simon Nemsadze

Georgian Technical University . Doctor of Technical Sciences. Full Professor

Tamar Giorgadze

Tbilisi State Medical University. Department of Histology, Cytology and Embryology. Assistant Professor.

Tamila Arnania-Kepuladze

Akaki Tsereteli State University. Department of Economics. PhD in Economic.

Tengiz Museliani

Georgian Technical University. Academic Doctor of Technical Sciences. Associate Professor

Timuri Babunashvili

Georgian Business Academy of Science. Doctor of Economical Sciences. Full Professor.

Vladimer Papava

Tbilisi State Medical University. Assistant-Professor. PhD. MD.

Zaira Gudushauri

Georgian-Azerbaijan University named G.Aliyev. Assosiate Professor. PhD. ES.

\section{Germany}

Hans-Juergen Zahorka

Assessor jur., Senior Lecturer (EU and International Law, Institutions and Economy), Chief Editor of "European Union Foreign Affairs Journal", LIBERTAS - European Institute, Rangendingen

Alexander Dilger

University of Münster. Professor of Business Economics. PhD in Economy.

\section{Greece}

Margarita Kefalaki

Communication Institute of Greece. PhD in Cultural Communication. President of Institute.

\section{Hungary}

Nicasia Picciano

Central European University. Department of International Relations and European Studies. 
India

Federica Farneti

University of Bologna. Department of Sociology and Business Low. Associate Professor. OhD in Economic \& Management.

Prasanta Kumar Mitra

Sikkim Manipal Institute of Medical Sciences. Deptartment of Medical Biotechnology. PhD in Biochemistry.

Samant Shant Priya

Lal Bahadur Shastri Institute of Management, New Delhi, Associate Professor in Philosophy PhD in Marketing.

Sonal Purohit

Jain University, Center for Management Studies, Assistant Professor, PhD in Business Administration, Life Insurance, Privatization.

Varadaraj Aravamudhan

Measi Instittue of Management. Associate Professor. PhD in Management.

Iraq

Rana Khudhair Abbas Ahmed

Irag, Baghdad, Alrafidain University College. Lecturer, Global Executive Administrator, Academic coordinator. PhD in Scholar (CS).

Iran

Azadeh Asgari

Asian Economic and Social Society (AESS). Teaching English as a Second Language. PhD

Italy

Simona Epasto

University of Macerata. Department of Political Science, Communication and International Relations. Tenured Assistant Professor in

Economic and Political Geography. PhD in Economic and Political Geography

Donatella M. Viola

London School of Economics and Political Science, London, Assistant Professor in Politics and International Relations at the University of Calabria, Italy. PhD in International Relations.

\section{Jordan}

Ahmad Aljaber

President at Gulf University. German Jordan University, Founder / Chairman of the Board. Ph.D in Computer Science

Ahmad Zamil

Middle East University (MEU). Business Administration Dept. Associate Professor. PhD Marketing

Ikhlas Ibrahim Altarawneh

Al-Huessien BinTalal University. Business Department. Full Professor in Human Resource Management.

Asmahan Majed Altaher

Arab Academy for Banking and Financial Sciences. Associate Professor. PhD in Management Information System.

Sadeq AlHamouz

Middle East University (MEU). Head Computer Information Systems. PHD. Computer Science.

Safwan Al Salaimeh

Aqaba University. Sofrware Engineering Department. Information Technology Faculty. Professor. PhD.

\section{Kazakhstan}

Alessandra Clementi

Nazarbayev University School of Medicine. MD, GP. Assistant Professor of Medical Practice and Family Medicine

Altinay Pozilova

Sirdarya University. Associated professor. PhD in Pedagogy Science.

Anar Mirazagalieva

Astana Internationl University. Vice-President. PhD in Biology.

Anna Troeglazova

East Kazakhstan State University named Sarsen Amanjolov. PhD

Gulmira Zhurabekova

Marat Ospanov West-Kazakhstan State Medical Academy. Department of Human Anatomy. Associate Professor

Guzel Ishkinina

Ust-Kamenogorsk, Russian Economy University G. Plekhanov, Associate Professor, PhD in Economic science.

Marina Bobireva

West Kazakhstan State Medical University named Marat Ospanov. PhD

Niyazbek Kalimov

Kostanay Agricultural Institution. PhD

Nuriya Kharissova

State University of Karaganda. Associate Professor of Biological Science

\section{PIRETC}


Nikolay Kurguzov

State University of Pavlodar named S. Toraygirova. PhD. Professor.

Oleg Komarov

Pavlodar State Pedagogical Institute. Professor of Department of Economics, Law and Philosophy. PhD in Sociology,

Zhanargul Smailova

Head of the Department of Biochemistry and Chemical Disciplines named after MD, professor S.O. Tapbergenova NAC Medical University of city Semey.

\section{Libya}

Salaheddin Sharif

University of Benghazi, International Conference on Sports Medicine and Fitness, Libyan Football Federation- Benghazi PhD in Medicine (MD)

\section{Latvia}

Tatiana Tambovceva

Latvian Council of Science. Riga Technical University. Assoiate Professor at Riga Technical University

\section{Lithuania}

Agne Simelyte

Vilnius Gediminas Technical University, Associate professor. Phd in Social Sciences (Management)

leva Meidute - Kavaliauskiene

Vilnius Gediminas Technical University. Vice-dean for Scientific Research

Vilma (Kovertaite) Musankoviene

e-Learning Technology Centre. Kaunas University of Technology. PHD

Laura Uturyte

Vilnius Gediminas Technical University (VGTU). Head of Project Manager at PI Gintarine Akademy. PhD in Economy.

Loreta (Gedminaitè) Ulvydiene

Professor of Intercultural Communication and Studies of Translation. Vilnius University. PHD

Zhaneta Simanavichienè

Professor, head of Laboratory Business Innovation University of Mykolas Romeris. Honorary consul of Estonia

\section{Macedonia}

Liza Alili Sulejmani

International Balkan University. Head of Banking and Finance department. Assistant Professor. PhD of Economics.

\section{Malaysia}

Anwarul Islam

The Millennium University. Department of Business Administration. Associate Professor.

Kamal Uddin

Millennium University, Department of Business Administration. Associate Professor. PhD in Business Administration.

\section{Morocco}

Mohammed Amine Balambo

Ibn Tufail University, Aix-Marseille University. Free lance. Consultant and Trainer. PhD in Philosophy. Management Sciences, Specialty Strategy and Logistics.

\section{Nigeria}

Bhola Khan

Yobe State University, Damaturu. Senior Lecturer and Head, Dept. of Economics. PhD in Economics.

\section{Norway}

Svitlana Holovchuk

$\mathrm{PhD}$ in general pedagogics and history of pedagogics.

\section{Pakistan}

Nawaz Ahmad

The Aga Khan University. Chief Examiner. PhD in Management. 
JOURNAL OF SOCIAL RESEARCH \& BEHAVIORAL SCIENCES

Poland

Grzegorz Michalski

Wroclaw University of Economics. Faculty of Engineering and Economics. PhD in economics. Assistant professor.

Kazimierz Waluch

Pawel Wlodkowic University College in Płock, Assistant Professor at the Faculty of Management. PhD in Economy.

Robert Pawel Suslo

Wroclaw Medical University, Public Health Department, Health Sciences Faculty, Adjunct Professor of Gerontology Unit. PhD MD.

Tadeusz Trocikowski

European Institute for Eastern Studies. PhD in Management Sciences.

\section{Qatar}

Mohammed Elgammal

Qatar University. Assistant Professor in Finance. PhD in Finance

\section{Romania}

Camelia Florela Voinea

University of Bucharest, Faculty of Political Science, Department of Political Science, International Relations and Security Studies.

$\mathrm{PhD}$ in Political Sciences.

Minodora Dobreanu

University of Medicine, Pharmacy, Sciences and Technology of Târgu Mureș. Faculty of Medicine. Professor. PhD in Medicine.

Odette (Buzea) Arhip

Ecological University Bucuresti. Professor at Ecological University. PhD.

\section{Russia}

Alexander A. Sazanov

Leningrad State University named A.S. Pushkin. Doctor of Biological Sciences. Professor

Alexander N. Shendalev

State Educational Institution of Higher Education. Omsk State Transport University. Associate Professor

Andrey Latkov

Stolypin Volga Region Institute of Administration, Ranepa. Sc.D. (Economics), Ph.D. (Politics), professor,

Andrei Popov

Director "ProfConsult Group". Nizhniy Novqorod Region. PhD

Anton Mosalyov

Russian State University of Tourism and Service. Associate Professor

Carol Scott Leonard

Presidential Academy of the National Economy and Public Administration. Vice Rector. PhD, Russian History

Catrin Kolesnikova

Samara Architectural and Constructional University. PhD

Ekaterina Kozina

Siberia State Transportation University. PhD

Elena Klemenova

South Federal University of Russia. Doctor of Pedagogical Sciences. Professor

Galina Kolesnikova

Russian Academy of Natural Sciences and International Academy of Natural History. Taganrog Institute of Management and

Economics. Philologist, Psychologist, PhD

Galina Gudimenko

Orel State Institute of Economics and Trade. Department of History, Philosophy, Advertising and Public Relations. Doctor of

Economical Sciences. Professor.

Grigory G. Levkin

Siberian State Automobile and Highway Academy. Omsk State Transport University. PHD of Veterinary Sciences

Gyuzel Ishkinina

Ust-Kamenogorsk affiliation of G. Plekhanov Russian Economy University / Associate Professor, Business, Informatics,

Jurisprudence and General Studies sub-department. PhD in Economic science.

Irina V. Larina

Federal State Educational Institution of Higher Professional Education. Associate Professor

Irina Nekipelova

M.T. Kalashnikov Izhevsk State Technical University. Department of Philosophy. PhD

Larisa Zinovieva

North-Caucasus Federal University. PHD.Pedagogical Science. Associate Professor

Liudmila Denisova

Department Director at Russian State Geological Prospecting University. Associate Professor

Lyalya Jusupowa

Bashkir State Pedagogical University named M.Akmully. PHD Pedagogy Science. Associate Professor 
Marina Sirik

Kuban State University. Head of the Department of Criminal Law, Process and Criminalistics of the State Pedagogical University.

$\mathrm{PhD}$ in Legal Sciences.

Marina Volkova

Research Institute of Pedagogy and Psychology. Doctor of Pedagogical Sciences. Professor

Natalia Litneva

Orlov State Institute of Economy and Trade. Volga Branch of The Federal State Budget Educational Institution of Higher Professional Education

Nikolay N. Efremov

Institute of Humanitarian Research and the Russian Academy of Sciences. Doctor of Philology. Research Associate

Nikolay N. Sentyabrev

Volgograd State Academy of Physical Culture. Doctor of Biological Sciences. Professor. Academician.

Olga Ovsyanik

Plekhanov Russian Economic University, Moscow State Regional University. Doctor in Social Psychology.

Olga Pavlova

Medical University named Rehabilitation, Doctors and Health, Professor of the Department of Morphology and Pathology, Doctor of

biological sciences, physiology

Sergei N. Fedorchenko

Moscow State Regional University of Political Science and Rights. PhD

Sergei A. Ostroumov

Moscow State University. Doctor of Biological Science. Professor

Svetlana Guzenina

Tambov State University named G.R. Derzhavin. PhD in Sociology

Tatiana Kurbatskaya

Kamsk State Engineering - Economical Academy. PhD

Victor F. Stukach

Omsk State Agrarian University. Doctor of Economical Sciences. Professor

Zhanna Glotova

Baltic Federal University named Immanuel Kant, Ph.D., Associate Professor.

\section{Saudi Arabia}

Ikhlas (Ibrahim) Altarawneh

Ibn Rushd College for Management Sciences. PHD Human Resource Development and Management.

Associate Professor in Business Administration

Salim A alghamdi

Taif University. Head of Accounting and Finance Dept. PhD Accounting

\section{Serbia}

Aleksandra Buha

University of Belgrade. Department of toxicology "Akademik Danilo Soldatović", Faculty of Pharmacy

Jane Paunkovic

Faculty for Management, Megatrend University. Full Professor. PhD, Medicine

Jelena Purenovic

University of Kragujevac . Faculty of Technical Sciences Cacak. Assistant Professor. PhD in NM systems.

\section{Sultanate of Oman}

Nithya Ramachandran

Ibra College of Technology. Accounting and Finance Faculty, Department of Business Studies. PhD

Rustom Mamlook

Dhofar University, Department of Electrical and Computer Engineering College of Engineering. PhD in Engineering / Computer Engineering. Professor.

\section{Sweden}

Goran Basic

Lund University. Department of Sociology. PhD in Sociology. Postdoctoral Researcher in Sociology.

\section{Turkey}

Fuad Aliew

Gebze Technical University, Department of Electronics Engineering, Faculty of Engineering,Associate professor, PhD in Automation engineering

Mehmet Inan

Turkish Physical Education Teachers Association. Vice president. PhD in Health Sciences, Physical Education and Sport Sciences 
Muzaffer Sancı

University of Health Sciences. Tepecik Research and Teaching Hospital. Clinics of Gynecology and Obtetrics Department of Gynecologic Oncologic Surgery. Assocciated Proffesor.

Vugar Djafarov

Medical school at the University of Ondokuzmayıs Turkey. PhD. Turkey.

Yigit Kazancioglu

Izmir University of Economics. Associate Professor, PhDin Business Administration.

\section{UK}

Christopher Vasillopulos

Professor of Political Science at Eastern Connecticut State University. PhD in Political Science and Government.

Frances Tsakonas

International Institute for Education Advancement. Ceo \& Founder. PhD in Philosophy.

Georgios Piperopoulos

Northumbria University. Visiting Professor, Faculty of Business and Law Newcastle Business School. PhD Sociology and Psychology.

Mahmoud Khalifa

Lecturer at Suez Canal University. Visiting Fellow, School of Social and Political Sciences, University of Lincoln UK. PhD in Social

and Political Sciences

Mohammed Elgammal

Qatar University. Assistant Professor. PhD in Finance.

Stephan Thomas Roberts

BP Global Project Organisation. EI\&T Construction Engineer. Azerbaijan Developments. SD 2 Onshore Terminal. Electrical engineer.

\section{Ukraine}

Alina Revtie-Uvarova

National Scientific Center. Institute of Soil Structure and Agrochemistry named Sokolovski. Senior Researcher of the Laboratory, performing part-time duties of the head of this laboratory.

Alla Oleksyuk-Nexhames

Lviv University of Medicine. Neurologyst at pedagog, pryvaty refleksoterapy. MD PD.

Anna Kozlovska

Ukrainian Academy of Banking of the National Bank of Ukraine. Associate Professor. PhD in Ecomomic.

Bogdan Storokha

Poltava State Pedagogical University. PhD

Dmytro Horilyk

Head of the Council, at Pharmaceutical Education \& Research Center. PhD in Medicine.

Galina Kuzmenko

Central Ukrainian National Technical University, Department of Audit and Taxation, Associate Professor.PhD in Economiy.

Galina Lopushniak

Kyiv National Economic University named after Vadym Hetman. PhD. Doctor of Economic Sciences, Professor.

Hanna Huliaieva

Institute of Microbiology and Virology, NASU, department of phytopatogenic bacteria. The senior research fellow, PhD in Biology.

Hanna Komarnytska

Ivan Franko National University of Lviv, Head of the Department of Economics and Management, Faculty of Finance and Business

Management, Ph.D. in Economics, Associate Professor.

Iryna Skrypchenko

Prydniprovsk State Academy of Physical Culture and Sports. Department of Water Sports. Associate Professor. PhD in Physical

Education and Sport.

Katerina Yagelskaya

Donetsk National Technical University. PhD

Larysa Kapranova

State Higher Educational Institution «Priazovskyi State Technical University» Head of the Department of Economic Theory

and Entrepreneurship, Associate Professor, PhD in Economy,

Lesia Baranovskaya

National Technical University of Ukraine "Kyiv Polytechnic Institute", PhD, Associate Professor.

Liliya Roman

Department of Social Sciences and Ukrainian Studies of the Bukovinian State Medical University. Associate professor, PhD in

Philology,

Lyudmyla Svistun

Poltava national technical Yuri Kondratyuk University. Department of Finance and Banking. Associated Professor.

Mixail M. Bogdan

Institute of Microbiology and Virology, NASU, department of Plant of viruses. PhD in Agricultural Sciences.

Nataliya Bezrukova

Yuri Kondratyuk National Technical University. Associate Professor, PhD in Economic.

Oleksandr Voznyak

Hospital "Feofaniya". Kyiv. Head of Neureosurgical Centre. Associated Professor 
Oleksandra Kononova

Prydniprovska State Academy of Civil Engineering and Architecture (PSACIA), Assoc.professor of Accounting, Economics and Human Resources Management department. PhD. in Economic Science.

Oleksandr Levchenko

Central Ukrainian National Technical University, Kropyvnytskyi. Vice-Rector for Scientific Activities. Professor.

Olena Cherniavska

Poltava University of Economics and Trade, Doctor of Economical Sciences. Professor

Olga F. Gold

Ukrainian National University named I.I. Mechnikov. PhD

Olga I. Gonchar

Khmelnytsky National University, Economics of Enterprise and Entrepreneurship, Doctor of Economic Sciences, Professor.

Roman Lysyuk

Assistant Professor at Pharmacognosy and Botany Department at Danylo Halytsky Lviv National Medical University.

Stanislav Goloborodko

Doctor of Agricultural Sciences, Senior Researcher. Institute of Agricultural Technologies of Irrigated Agriculture of the National Academy of Agrarian Sciences of Ukraine

Svetlana Dubova

Kyiv National University of Construction and Architecture. Department of Urban Construction. Associate Professor. PhD in TS.

Kyiv Cooperative Institute of Business and Law

Tetiana Kaminska

Kyiv Cooperative Institute of Business and Law. Rector. Doctor of Science in Economics.

Valentina Drozd

State Scientific Research Institute of the Ministry of Internal Affairs of Ukraine. Doctor of Law, Associate Professor, Senior

Researcher.

Vasyl Klymenko

Central Ukrainian National Technical University. Department of Electrical Systems and Energy Management. Doctor TS. Professor.

Victoriya Lykova

Zaporizhzhya National University, PhD of History

Victor P. Mironenko

Doctor of Architecture, professor of department "Design of architectural environment", Dean of the Faculty of Architecture of Kharkov

National University of Construction and Architecture (KNUCA), member of the Ukrainian Academy of Architecture

Yuliia Mytrokhina

Donetsk National University of Economics and Trade named after Mykhaylo Tugan-Baranovsky., PhD in Marketing and Management.

Associate Professor

Yulija M. Popova

Poltava National Technical University named Yuri Kondratyuk. PhD in Ecomomic. Assiciated professor

\section{Crimea}

Lienara Adzhyieva

V.I. Vernadsky Crimean Federal University, Yevpatoriya Institute of Social Sciences (branch). PhD of History. Associate Professor Oksana Usatenko

V.I. Vernadsky Crimean Federal University. Academy of Humanities and Education (branch). PhD of Psychology.

Associate Professor.

Oleg Shevchenko

V.I. Vernadsky Crimean Federal University, Humanities and Education Science Academy (branch), Associate Professor. PhD in

Social Philosophy

Tatiana Scriabina

V.I. Vernadsky Crimean Federal University, Yevpatoriya Institute of Social Sciences (filial branch). PhD of Pedagogy.

Associate Professor

United Arab Emirates

Ashok Dubey

Emirates Institute for Banking \& Financial Studies, Senior faculty. Chairperson of Academic Research Committee of EIBFS.

$\mathrm{PhD}$ in Economics

Maryam Johari Shirazi

Faculty of Management and HRM. PhD in HRM. OIMC group CEO.

USA

Ahmet S. Yayla

Adjunct Professor, George Mason University, the Department of Criminology, Law and Society \& Deputy Director, International Center for the Study of Violent Extremism (ICSVE), PhD in Criminal Justice and Information Science

Christine Sixta Rinehart

Academic Affairs at University of South Carolina Palmetto College. Assistant Professor of Political Science. Ph.D. Political Science Cynthia Buckley

Professor of Sociology at University of Illinois. Urbana-Champaign. Sociological Research 
Medani P. Bhandari

Akamai University. Associate professor. Ph.D. in Sociology.

Mikhail Z. Vaynshteyn

Lecturing in informal associations and the publication of scientific articles on the Internet. Participation in research seminars in the

"SLU University" and "Washington University", Saint Louis

Nicolai Panikov

Lecturer at Tufts University. Harvard School of Public Health. PhD/DSci, Microbiology

Rose Berkun

State University of New York at Buffalo. Assistant Professor of Anesthesiology, PhD. MD

Tahir Kibriya

Director technical / senior engineering manager. Black \& Veatch Corporation, Overland Park. PhD Civil Engineering.

Yahya Kamalipour

Dept. of Journalism and Mass Communication North Carolina A\&T State University Greensboro, North Ca. Professor and Chair Department of Journalism and Mass Communication North Carolina A\&T State University. PhD

Wael Al-Husami

Lahey Hospital \& Medical Center, Nardone Medical Associate, Alkhaldi Hospital, Medical Doctor, International Health, MD, FACC, FACP

\section{Uruguay}

Gerardo Prieto Blanco

Universidad de la República. Economist, Associate Professor . Montevideo.

\section{Uzbekistan}

Guzel Kutlieva

Institute of Microbiology. Senior Researcher. PhD in BS.

Khurshida Narbaeva

Institute of Microbiology, Academy of Sciences Republic of Uzbekistan, Doctor of biological sciences.

Shaklo Miralimova

Academy of Science. Institute of Microbiology. Doctor of Biology Sciences. PhD in BS.

Shukhrat Yovkochev

Tashkent State Institute of Oriental Stadies. Full professor. PhD in political sciences. 


\section{AIMS AND SCOPE}

ICRET MTÜ The Baltic Scientific Journals publishes peer-reviewed, original research and review articles in an open access format. Accepted articles span the full extent of the social and behavioral sciences and the humanities.

ICRET MTÜ The Baltic Scientific Journals seeks to be the world's premier open access outlet for academic research. As such, unlike traditional journals, ICRET MTÜ The Baltic Scientific Journals does not limit content due to page budgets or thematic significance. Rather, ICRET MTÜ The Baltic Scientific Journals evaluates the scientific and research methods of each article for validity and accepts articles solely on the basis of the research. Likewise, by not restricting papers to a narrow discipline, ICRET MTÜ The Baltic Scientific Journals facilitates the discovery of the connections between papers, whether within or between disciplines.

ICRET MTÜ The Baltic Scientific Journals offers authors quick review and decision times; a continuous-publication format; and global distribution for their research via ICRET MTÜ The Baltic Scientific Journals Online. All articles are professionally copyedited and typeset to ensure quality.

Those who should submit to ICRET MTÜ The Baltic Scientific Journals include:

- Authors who want their articles to receive quality reviews and efficient production, ensuring the quickest publication time.

- Authors who want their articles to receive free, broad, and global distribution on a powerful, highly discoverable publishing platform.

- Authors who want their articles branded and marketed by a world-leading social science publisher.

- Authors who want or need their articles to be open access because of university or government mandates. 


\section{TOPICS OF JOURNAL}

\section{AGRICULTURAL, ENVIRONMENTAL \& NATURAL SCIENCES}

Agriculture, Agronomy \& Forestry Sciences

History of Agricultural Sciences

Plant Breeding and Seed Production

Environmental Engineering Science

Earth Sciences \& Organic Farming

Environmental Technology

Botany, Zoology \& Biology

\section{SOCIAL, PEDAGOGY SCIENCES \& HUMANITIES}

Historical Sciences and Humanities

Psychology and Sociology Sciences

Philosophy and Philology Sciences

History of Science and Technology

Social Science

Pedagogy Science

Politology

Geography

Linguistics

\section{MEDICINE AND BIOLOGY SCIENCES}

Clinical Medicine

Prophylactic Medicine

Theoretical Medicine

Stomatology \& Dentistry

Innovations in Medicine

Biophysics and Biochemistry

Radiology and Microbiology

Molecular Biology and Genetics

Botany and Virology

Microbiology and Hydrobiology

Physiology of Plants, Animals and Humans

Ecology, Immunology and Biotechnology

Virology and Immunology

History of Biology

Entomology 


\section{COMPUTING AND APPLIED SCIENCES}

History of Science and Technics

Information, Computing and Automation

Innovative Technologies

Mathematics \& Applied Mathematics

\section{ECONOMIC, MANAGEMENT \& MARKETING SCIENCES}

Economics and Management of Enterprises

Economy and Management of a National Economy

Mathematical Methods, Models and Information Technologies in Economics

Accounting, Analysis and Auditing

Money, Finance and Credit

Demography, Labor Economics

Management and Marketing

Economic Science

\section{LEGAL, LEGISLATION AND POLITICAL SCIENCE}

Theory and History of State and Law

International Law

Branches of Law

Judicial System and Philosophy of Law

Theory and History of Political Science

Political Institutions and Processes

Political Culture and Ideology

Political Problems of International Systems and Global Development 
NGO International Center for Research, Education \& Training (Estonia, Tallinn) is publishing scientific papers of scientists on Website and in Referred Journals with subjects which are mentioned below:

(C) The Baltic Scientific Journals

ISSN: 2613-5817; E-ISSN: 2613-5825; UDC: 0 (0.034);

DOI PREFIX: 10.36962/PIRETC

Proceeding of The International Research Education \& Training Center.

https://scia.website/index.php/piretc

ISSN: 2674-4562, E-ISSN: 2674-4597, UDC: 620.9 (051) (0.034);

DOI PREFIX: 10.36962/ENECO

Proceedings of Energy Economic Research Center. ENECO

https://scia.website/index.php/eneco

ISSN: 1609-1620, E-ISSN: 2674-5224; UDC: 62 (051) (0.034);

DOI PREFIX: 10.36962/PAHTEI

Proceedings of Azerbaijan High Technical Educational Institutions. PAHTEI

https://scia.website/index.php/pahtei

ISSN: 2663-8770, E-ISSN: 2733-2055; UDC: 672, 673, 67.01-67.02

DOI PREFIX: 10.36962/ETM

ETM Equipment, Technologies, Materials

https://scia.website/index.php/etm

ISSN: 2733-2713; E-ISSN: 2733-2721; UDC: 33

DOI PREFIX: 10.36962/SWD

SOCIO WORLD-SOCIAL RESEARCH \& BEHAVIORAL SCIENCES

https://scia.website/index.php/swd

E-ISSN: 2587-4713; UDC: 620.9 (051) (0.034)

DOI PREFIX: 10.36962 / ECS

Economics

https://scia.website/index.php/ecs 
Society of Azerbaijanis living in Georgia. NGO. (Georgia, Tbilisi) is publishing scientific papers of scientists on Website and in Referred Journals with subjects which are mentioned below:

\section{(C) Southern Caucasus Scientific Journals}

ISSN: 2346-8068; E-ISSN: 2346-8181; UDC: 611-618

DOI PREFIX: 10.36962/ALISJMSC

Ambiance in Life-International Scientific Journal in Medicine of Southern Caucasus. https://scia.website/index.php/AILISJMSC

\section{Representation of the International Diaspora Center of Azerbaijan in Georgia. NGO}

(Georgia Tbilisi) is publishing scientific papers of scientists on Website and in Referred Journals with subjects which are mentioned below:

\section{(C) Southern Caucasus Scientific Journals}

ISSN: 2298-0946, E-ISSN: 1987-6114; UDC: 3/k-144

DOI PREFIX: 10.36962/CESAJSC

The Caucasus-Economic and Social Analysis Journal of Southern Caucasus https://scia.website/index.php/CESAJSC 


\section{VOLUME 17 ISSUE 072021}

[Review Article Template]

[This Review Article Template has the standard set of headings that make up different sections of the manuscript.]

[Below the headings the dummy text is given in red color.]

[Delete the dummy text in red color and replace it with your own text.]

[You can directly type your text here or copy your text from your file and paste it at the appropriate place.]

[Delete any section or heading you do not need.]

[If you need more than one set of headings, you can copy and past the headings.]

[Keep the right margin of the text ragged. Do not use "Justify text" command.]

[Please make sure that the reference format conforms to the journal reference style.]

[DO NOT FORGET TO FREQUENTLY SAVE THIS FILE WHILE WORKING ON THIS MANUSCRIPT TO

PREVENT LOSS OF DATA.]

[DOUBLE SPACE THE MANUSCRIPT THROUGHOUT (Title Page need not be double spaced)]

[DELETE ALL TEXT IN RED COLOR BEFORE SUBMITTING YOUR MANUSCRIPT.]

TITLE: PAPER TITLE (Title, Times New Roman, bold, 14)

[Enter here the title of manuscript in sentence case (14 Bold)-capital letter.]

AUTHORS: [List here all author names; identify authors with author affiliations with superscript Arabic numerals]

[First Name Middle Name Family Name ${ }^{1}$ ], [First Name Middle Name Family Name ${ }^{2}$ ] [First Name Middle Name Family Name ${ }^{3}$ ], [First Name Middle Name Family Name ${ }^{4}$ ] (Author(s), Times New Roman, bold, 12)

AFFILIATIONS: [List here all author affiliations including position in the department, department, institute, city, state, country, email; identify authors with author affiliations with superscript Arabic numerals]

${ }^{1}$ [Author affiliations - position, department, institute, city, state, country, email ID, ORCID ID]

${ }^{2}$ [Author affiliations - position, department, institute, city, state, country, email ID, ORCID ID]

3 [Author affiliations - position, department, institute, city, state, country, email ID, ORCID ID] (Affiliation1,2,3 Times New Roman, 10)

\section{CORRESPONDING AUTHOR DETAILS}

[Give here name, contact address, contact phone number, email and fax number of the corresponding author, Corresponding author must be one of the authors of the manuscript.]

[First Name Middle Name Family Name]

[Complete Mailing Address]

[City]

[State]

[Country]

[Postal Code]

[Contact Phone Number - Country prefix followed by full phone number]

[Contact Email]

[Fax number - Country prefix followed by full fax number]

(Affiliation for CA Times New Roman, 10)

Short Running Title: [Give here a short title of the paper, less than 40 characters] (Times New Roman, 10)

Guarantor of Submission: The corresponding author is the guarantor of submission.

[If an author other than the corresponding author is the Guarantor of Submission, delete the previous line, write the name of the individual and give the details below.]

(Times New Roman, 10)

\section{Guarantor of Submission (if not the corresponding author)}

[Give here name, contact address, contact phone number, email and fax number of the guarantor of Submission, if other than the corresponding author] 
[First Name Middle Name Family Name]

[Complete Mailing Address]

[City]

[State]

[Country]

[Postal Code]

[Contact Phone Number - Country prefix followed by full phone number]

[Contact Email]

[Fax number - Country prefix followed by full fax number]

(Times New Roman, 10)

SUMMARY (OPTIONAL) (Times New Roman, 12 Bold)

[This section of the manuscript is optional. It is up to the author(s) to decide whether to include this section in the manuscript.]

["Summary" of your work is a short description of the work being presented in your article. It is longer than the "Abstract" which is limited to 250 words for all types of articles. After reading the "Summary" a reader should be able to understand the background information, why the work is being reported, what the significant results are, and what may be the explanation for the results.]

[Although writing an additional section in the form of "Summary" of your work may seem like and extra burden on your time and resources, it will be an important part of your manuscript especially for articles which are highly technical. Many times readers who are students, or who are not expert on the subject of the article or readers who are experts but in related subjects may skip reading an article if on first look the article appears to be very technical with lot of data, facts and statistics. Some other articles may not be easy to understand, on first reading, even by experts in the subject of the article. The "Summary" section will help the readers in understanding the results of your study.]

- The recommended word limit for "Summary" for Review Article is - 800 words (2 pages)

- When writing the "Summary" use as simple and as non-technical language as possible. Write the "Summary" as if you are explaining your study to a first year graduate student.

- Do not repeat or copy text verbatim from the main text of your manuscript. "Summary" will probably be the most important and most widely read part of your manuscript. Write it fresh as a separate section.

- In the "Summary" give: 1) relevant background information, 2) why the work was done, 3) what were the significant results, 4) possible explanation of the results.

- Only give the significant results of your study and give their possible explanation.

- Do not compare your results with other studies.

- Do not give references in the "Summary" section. First reference should start in main text of your manuscript from the "Introduction" section.

TITLE: [Enter Here the Title of Manuscript in Sentence Case.]

ABSTRACT (Times New Roman, 12)

OBJECTIVE: (Times New Roman, 12)

METHODS: (Times New Roman, 12)

RESULTS: (Times New Roman, 12)

CONCLUSION: (Times New Roman, 12)

[Structured or unstructured abstract as required by the manuscript]

[Less than 250 words for all manuscripts]

Keywords: [Four to six keywords for indexing purpose] (Times New Roman, 12)

TITLE: [Enter here the title of manuscript in sentence case.] (Times New Roman, 12)

[Type or copy/paste the manuscript text under the headings below. References are in square brackets, e.g. [1, 2, 3] and figures/tables are in parenthesis, e.g. (Figure 1) or (Table 1)] 
INTRODUCTION (Times New Roman, 12 Bold)

[Type or copy/paste your text here]

(Times New Roman, 12)

[After "INTRODUCTION" rest of the headings or subheadings can be as required by the manuscript]

[Heading (level 1 heading is in CAPITALS followed by text)] (Times New Roman, 12 Bold)

DDDD DDDD DDDDDD DDDDDDDD DDDDDD DDDDDDD DDDDD DDDDD DDDDD]

(Times New Roman, 12)

[Subheading (level 2 heading is in sentence case, followed by text) (Times New Roman, 12 Bold)

DDDD DDDD DDDDDD DDDDDDDD DDDDDD DDDDDDD DDDDDDD DDDDDDDDD]

(Times New Roman, 12)

[Subheading (level 3 heading is in sentence case, in line with text) (Times New Roman, 12 Bold) DDDD DDDD

DDDDDD DDDDDDDD DDDDDD DDDDDDD DDDDDD DDDD DDD D D DDDD DDDDDD D D DD DD]

(Times New Roman, 12)

CONCLUSION (Times New Roman, 12 Bold)

[Type or copy/paste your text here]

(Times New Roman, 12)

CONFLICT OF INTEREST (Times New Roman, 10 Bold)

[Declare here if any financial interest or any conflict of interest exists. ]

(Times New Roman, 10)

AUTHOR'S CONTRIBUTIONS (Times New Roman, 10 Bold)

[Enter name of authors followed by author's contribution.]

[At least one task from each group is required from an individual to be listed as author of the article, delete anything which is not applicable.]

(Times New Roman, 10)

[First Name Middle Name Family Name]

Group1 - Conception and design, Acquisition of data, Analysis and interpretation of data

Group 2 - Drafting the article, Critical revision of the article

Group 3 - Final approval of the version to be published

(Times New Roman, 10)

[First Name Middle Name Family Name]

Group1 - Conception and design, Acquisition of data, Analysis and interpretation of data

Group 2 - Drafting the article, Critical revision of the article

Group 3 - Final approval of the version to be published

(Times New Roman, 10)

[First Name Middle Name Family Name]

Group1 - Conception and design, Acquisition of data, Analysis and interpretation of data

Group 2 - Drafting the article, Critical revision of the article

Group 3 - Final approval of the version to be published

(Times New Roman, 10)

[First Name Middle Name Family Name]

Group1 - Conception and design, Acquisition of data, Analysis and interpretation of data

Group 2 - Drafting the article, Critical revision of the article

Group 3 - Final approval of the version to be published

(Times New Roman, 10) 
[First Name Middle Name Family Name]

Group1 - Conception and design, Acquisition of data, Analysis and interpretation of data

Group 2 - Drafting the article, Critical revision of the article

Group 3 - Final approval of the version to be published

(Times New Roman, 10)

[First Name Middle Name Family Name]

Group1 - Conception and design, Acquisition of data, Analysis and interpretation of data

Group 2 - Drafting the article, Critical revision of the article

Group 3 - Final approval of the version to be published

(Times New Roman, 10)

ACKNOWLEDGEMENTS (Times New Roman, 12 Bold)

[List here any individuals who contributed in the work but do not qualify for authorship base on the above criteria.]

REFERENCES (Times New Roman, 12 Bold)

[List here all the references in the order of citation in the text. List all authors if less than six. If more than six authors, list the first six followed by "et.al."]

[General style of reference is:]

[Surname First Name Middle Name, Surname First Name Middle Name. Title of article. Journal Name

Year;Volume(Number):Full inclusive page numbers.]

[NO SPACES BETWEEN - Year;Volume(Number):Full inclusive page numbers. ]

1. [Surname First Name Middle Name, Surname First Name Middle Name. Title of article. Journal Name Year; Volume(Number):Full inclusive page numbers.]

2. [Surname First Name Middle Name, Surname First Name Middle Name. Title of article. Journal Name Year;Volume(Number):Full inclusive page numbers.]

3. [Reference 3]

4. [Reference 3]

5. [Reference 3]

6. [Reference 3]

(Times New Roman, 12 Bold)

SUGGESTED READING (Times New Roman, 12 Bold)

[In this section include references to articles, abstracts, books, manuals, web pages, videos, presentations or any other material you have referred to in planning and writing your study which are either not directly relevant to your study or not important enough to be cited in the text and given in the "References" section.]

[Include any number of items in this section, but we suggest you to limit the number to 15 or less for review articles and original articles and 10 or less for case series and case reports.]

[Please DO NOT cite the items in the "Suggested Reading" section in the text of your manuscript.]

TABLES (Times New Roman, 12 Bold)

[All tables should be double spaced. Each table on a separate page]

Table 1: [Type or copy/paste here a brief descriptive title of the table DO NOT use full-stop after table sentence] (Times New Roman, 12)

\begin{tabular}{|l|l|l|l|l|}
\hline & & & & \\
\hline & & & & \\
\hline & & & & \\
\hline
\end{tabular}


Abbreviations: [Give here full form of all abbreviations used in the table. Give the full form even if it has been explained in the text.]

[All tables should be double spaced. Each table on a separate page]

Table 2: [Type or copy/paste here a brief descriptive title of the table DO NOT use full-stop after table heading] (Times New Roman, 12)

\begin{tabular}{|l|l|l|l|l|}
\hline & & & & \\
\hline & & & & \\
\hline & & & & \\
\hline
\end{tabular}

Abbreviations: [Give here full form of all abbreviations used in the table. Give the full form even if it has been explained in the text.]

FIGURE LEGENDS (Times New Roman, 12 Bold)

Figure 1: [Give here a description of figures/image, include information like contrast media, stain, chemical, power used, protect patient privacy at all times. End the legend with full stop.]

(Times New Roman, 12)

Figure 2: (A) - [If a figure has many parts give here a description of part of figures/image, include information like contrast media, stain, chemical, power used, protect patient privacy at all times; (B) - [Give here a description of part of figures/image, include information like contrast media, stain, chemical, power used, protect patient privacy at all times. End legend with full stop.]

(Times New Roman, 12) 


\section{NOTES}

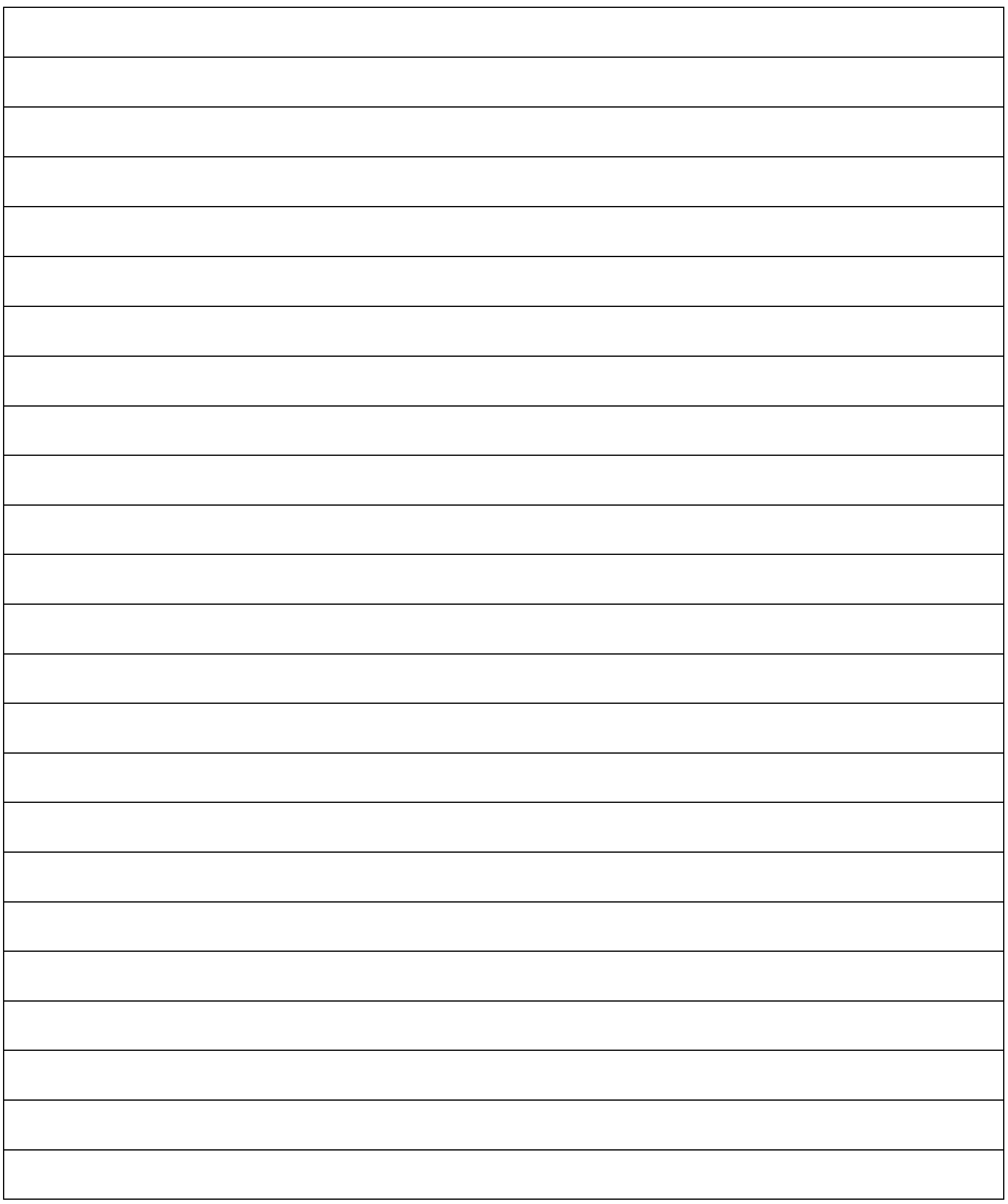

